\title{
THE VIRTUES OF KNOWING LESS: JUSTIFYING PRIVACY PROTECTIONS AGAINST DISCLOSURE
}

\author{
DANIEL J. SOLOVE $\dagger$
}

\begin{abstract}
This Article develops justifications for protections against the disclosure of private information. An extensive body of scholarship has attacked such protections as anathema to the Information Age, where the free flow of information is championed as a fundamental value. This Article responds to two general critiques of disclosure protections: (1) that they inhibit freedom of speech, and (2) that they restrict information useful for judging others.

Regarding the free speech critique, the Article argues that not all speech is of equal value; speech of private concern is less valuable than speech of public concern. The difficulty, however, is distinguishing between public and private concerns. Traditional approaches include deferring to the media, distinguishing between public and private figures, and looking to the nature of the information disclosed. However, these approaches are flawed. Instead, we should focus on the relationships in which information is transferred and the uses to which information is put. The propriety of disclosures depends upon their purpose, not merely on the type of
\end{abstract}

Copyright (C) 2003 by Daniel J. Solove.

$\dagger \quad$ Visiting Professor, George Washington University Law School; Associate Professor, Seton Hall Law School; J.D., Yale. Special thanks to Mark Alexander, Anita Allen, Julie Cohen, Thomas Dienes, Howard Erichson, Robert Gellman, Rachel Godsil, Thomas Healy, Laura Heymann, Stan Karas, Raymond Ku, Douglas Lichtman, Erik Lillquist, Jon Michaels, Marc Poirier, Neil Richards, Peter Sand, Paul Schwartz, Lior Strahilevitz, Charles Sullivan, Michael Sullivan, and Sarah Waldeck for their thoughtful comments. This Article has also benefited from the insights of participants at workshops at George Washington University Law School and Hofstra Law School. Additionally, the participants of the Seton Hall Law School scholarship retreat provided very helpful suggestions. Jessica Kahn, Romana Kaleem, Poornima Ravishankar, and John Spaccarotella provided excellent research assistance. Finally, I would like to thank the Seton Hall faculty scholarship fund for its generous support for this project. 
information disclosed. The Article analogizes to the law of evidence, in which certain information is admissible for some purposes but not others and then examines the values of free speech and argues that privacy often furthers the same ends, demonstrating that free speech should not always prevail in the balance.

Next, the Article tackles the judgment and trust critique, which views personal information as essential for making judgments about whether to trust people with whom one associates. Although personal information can help facilitate judgments about other people, the Article contends that these judgments are often made quickly and out of context. In short, more information does not necessarily lead to more accurate judgments. The Article also contends that privacy protects against certain rational judgments that society may want to prohibit (such as employment decisions based on genetic information). The Article then responds to commentators who argue that gossip is valuable because it helps educate us about human nature and argues that the value of concealing one's past can, in many circumstances, outweigh the benefits of disclosure.

Introduction 969

I. The Free Speech Critique ............................................................976

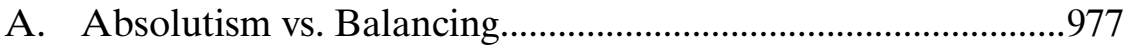

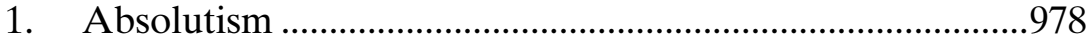

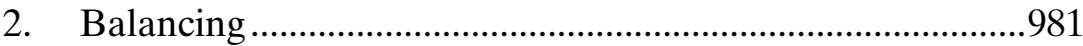

B. Balancing Free Speech and Privacy ........................................989

1. Individual Autonomy..............................................................990

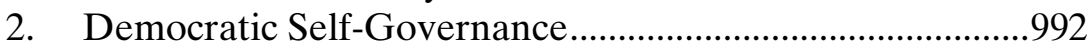

3. The Marketplace of Ideas......................................................998

C. Distinguishing Public from Private Concerns .........................1000

1. Prevailing Approaches...........................................................1001

2. Looking to the Law of Evidence: A More Contextual

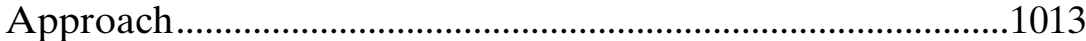

3. The Problem of Hyper-Contextualism ...............................1025

D. Reassessing the Free Speech Critique ..................................1030

II. The Judgment and Trust Critique ................................................1032

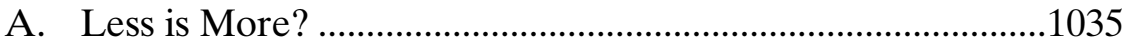

1. Judging Out of Context ...................................................1035

2. The Trouble with Irrational—and Rational-Judgment.1041

3. Gossip and Judgments about Human Nature ....................1044

4. Problems with Regulating Judgment. ..................................1047 
B. Concealing the Past: Growth and Reformation.....................1053

C. Reassessing the Judgment and Trust Critique ........................1063

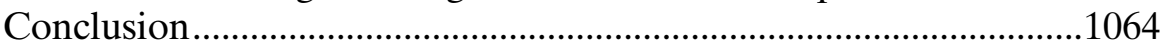

[Y]ou can't keep out the light of the Press. Now what I'm going to do is to set up the biggest lamp yet made and to make it shine all over the place. We'll see who's private then!

— Henry James, The Reverberator (1888) ${ }^{1}$

\section{INTRODUCTION}

When is it justifiable for the law to prohibit the disclosure of another person's private information? This question has long confounded courts and troubled scholars. The question is especially perplexing in today's Information Age, when the free flow of information is championed as a fundamental value. Of course, people conceal private information everyday, and relatively few would contend that it should be impermissible to keep certain personal information hidden. But should the law help people conceal information?

Today, the ease of disseminating personal information is unprecedented. The media has grown hungrier for stories, which are needed to fill the vast array of news shows, the growing number of twenty-four-hour cable news networks, and the tens of thousands of magazines, newspapers, and websites. Without warning, anyone can broadcast another's unguarded moments or times of youthful awkwardness to an audience of millions. In addition, companies that archive Internet data ensure that embarrassing material follows a victim for life, while Google and other search engines provide instantaneous access to a wealth of personal information. More and more people are keeping "blogs" (short for "web logs"), where they post their thoughts and pictures on the Internet. ${ }^{2}$ Blogs can reveal intimate details about friends, enemies, jilted lovers, and others. To give one example, an awkward and overweight fifteen-year-old kid

1. Henry JAMES, THE REVERBERATOR 68 (1888).

2. See Warren St. John, Dating a Blogger, Reading All About It, N.Y. TIMES, May 18, 2003 , $§$, at 1 ("[B]logging [is] a once marginal activity of Internet enthusiasts that has become squarely mainstream.”). 
recorded a short video cassette of himself and pretended to be a character from the movie Star Wars: Episode I-The Phantom Menace. ${ }^{3} \mathrm{He}$ danced around with a golf ball retriever pretending it was a light saber, making his own sound effects. Somebody found the video, converted it to digital format, and posted it on the Internet, where it was then downloaded millions of times across the globe. One blogger even created a version of the video with special effects and music. Websites were barraged by postings making fun of the kid. "People were laughing at me," the kid wrote, "[a]nd it was not funny at all."

Beyond disclosure by the media and on websites, increasingly personal information is being traded among companies, which maintain extensive dossiers about millions of individuals. ${ }^{5}$ These dossiers are stored and transferred in vast databases, and they contain details about people's race, hobbies, income, finances, family life, purchases, and lifestyle. ${ }^{6}$ Credit reporting agencies routinely disclose personal information when advising creditors about a person's creditworthiness. ${ }^{7}$ This data affects people's lives in profound waysdetermining whether they get a loan, a job, a mortgage, or a license.

Given the development of technologies that permit extensive data gathering and dissemination, deciding how to regulate the disclosure of personal information is a vital issue. Currently, a significant body of law, comprised of both common law and statutes, restricts the disclosure of personal information. Within this legal framework, the most controversial and frequently debated protection against disclosure is tort law's prohibition against public disclosure of private facts. The tort of public disclosure originates from an 1890 article by Samuel Warren and Louis Brandeis, The Right to Privacy, in which they argued that the "press is overstepping in every direction the obvious bounds of propriety and of decency."

3. Amy Harmon, Fame is No Laughing Matter for the "Star Wars Kid," N.Y. TIMES, May 19, 2003, at C3.

4. Id.

5. See Daniel J. Solove, Privacy and Power: Computer Databases and Metaphors for Information Privacy, 53 STAN. L. REV. 1393, 1403-13 (2001) (describing a variety of data collection, storage, and vending techniques).

6. Id. at 1406, 1409-11.

7. See Daniel J. Solove, Identity Theft, Privacy, and the Architecture of Vulnerability, 54 HASTINGS L.J. 1227, 1245 (2003) ("[C]reditors rely upon credit reporting agencies to obtain information about a person's credit history.").

8. Samuel D. Warren \& Louis D. Brandeis, The Right to Privacy, 4 HARV. L. REV. 193, $196(1890)$. 
that the press had "invaded the sacred precincts of private and domestic life" and that gossip had become "a trade." Today, the vast majority of states have created tort actions in response to the Warren and Brandeis article. ${ }^{10}$ Under the public disclosure tort, a person has a cause of action when another widely discloses a private matter that is "highly offensive to a reasonable person" and "is not of legitimate concern to the public." puzzles of tort law. It enables people to sue others for disclosing true information about them, even if the information was obtained through lawful means.

In addition to the tort of public disclosure, the common law provides a number of other protections against the disclosure of personal information. For example, a tort for breach of confidentiality remedies disclosures of medical information by physicians and financial data by banks. ${ }^{12}$ Liability under this tort even extends to third parties who induce the disclosure. ${ }^{13}$

On the statutory side of the law, there is a panoply of federal and state statutes that limit disclosures of personal data. A number of federal statutes restrict disclosure of information from school

9. Id.

10. See Lake v. Wal-Mart Stores, Inc., 582 N.W.2d 231, 235 (Minn. 1998) (noting that Minnesota was one of the few states that had not recognized the privacy torts, but reversing course and embracing the torts). The only states not recognizing any of the privacy torts are North Dakota and Wyoming. Robert M. O'NeIL, The First AMENDMENT AND CIVIL LIABILITY 77 (2001). The recognition of tort actions to protect privacy began in the early twentieth century. New York enacted a statute to protect privacy in 1903. Act of April 6, 1903, ch. 132, 1903 N.Y. Laws 308, 308 (codified as amended at N.Y. CIV. RIGHTS LAW §§ 50-51 (McKinney 1992)). The law was passed in response to a 1902 New York Court of Appeals decision rejecting a common law basis for the Warren and Brandeis privacy tort. Roberson v. Rochester Folding Box Co., 64 N.E. 442, 447 (N.Y. 1902). In 1905, the Georgia Supreme Court recognized a common law tort for privacy invasions. Pavesich v. New England Life Ins. Co., 50 S.E. 68, 80-81 (Ga. 1905). In 1960, tort scholar William Prosser identified four distinct privacy torts that had developed through the 300 cases based on the Warren and Brandeis article. William L. Prosser, Privacy, 48 CAL. L. REv. 383, 388-89 (1960). The torts are (1) public disclosure of private facts, (2) intrusion upon seclusion, (3) false light, and (4) appropriation. Id. at 389 .

11. Restatement (SECOND) OF TORTS § 652D (1977).

12. Peterson v. Idaho First Nat'l Bank, 367 P.2d 284, 290 (Idaho 1961) (finding a breach of confidentiality tort for disclosure by bank); McCormick v. England, 494 S.E.2d 431, 439 (S.C. Ct. App. 1997) (finding a breach of confidentiality tort for disclosure by a physician). For more information on the breach of confidentiality tort, see generally Alan B. Vickery, Note, Breach of Confidence: An Emerging Tort, 82 COLUM. L. REV. 1426 (1982).

13. Hammonds v. AETNA Cas. \& Sur. Co., 243 F. Supp. 793, 803 (N.D. Ohio 1965). 
records ${ }^{14}$ cable company records,${ }^{15}$ video rental records, ${ }^{16}$ motor vehicle records ${ }^{17}$ and health records. ${ }^{18}$ Specifically, the Fair Credit Reporting Act restricts the permissible uses of credit reports ${ }^{19}$ and regulates the disclosures that credit reporting agencies can make. ${ }^{20}$ Various states have also restricted the disclosure of particular forms of information, such as data about health, ${ }^{21}$ alcohol and drug abuse, ${ }^{22}$ sexual offense victims, ${ }^{23}$ HIV status, ${ }^{24}$ abortion patients, ${ }^{25}$ and mental illness. $^{26}$

However, protections against the disclosure of true information often conflict with important values: freedom of speech, freedom of the press, an employer's ability to know more about employees, and more complete knowledge of the people we deal with. Prodisclosure arguments have gained a lot of currency in legal scholarship and

14. Family Educational Rights and Privacy Act of 1974, 20 U.S.C. $\$ 1232 \mathrm{~g}(2000)$.

15. Cable Communications Policy Act of $1984 \S 631,47$ U.S.C. $\S 551$ (2000).

16. Video Privacy Protection Act of 1988, 18 U.S.C. $\$ \S 2710-11$ (2000).

17. Driver's Privacy Protection Act of 1994, 18 U.S.C. $\$ \S 2721-25$ (2000).

18. Health Insurance Portability and Accountability Act of 1996, Pub. L. No. 104-191, 110 Stat. 1936 (codified as amended in scattered sections of 18, 26, 29, and 42 U.S.C.).

19. 15 U.S.C. $\S 1681 b(3)$ (2000).

20. For example, for certain transactions, the FCRA prohibits the reporting of bankruptcies over ten years old and criminal records over seven years old. 15 U.S.C. § 1681c(a).

21. See, e.g., Cal. Health \& SAFETy Code $§ 120,975$ (West 1996) (prohibiting disclosure of HIV test results); N.Y. PUB. Health LaW $§ 17$ (McKinney 2002) (prohibiting the nonconsensual disclosure of medical records of minors relating to sexually transmitted diseases and abortion; even the disclosure to parents is prohibited without consent).

22. See, e.g., 71 PA. CONS. STAT. ANN. $\$ 1690.108$ (West 1990) (prohibiting the disclosure of all records prepared during alcohol or drug abuse treatment).

23. See, e.g., Cal. Evid. Code $§ 352.1$ (West 1995); ConN. Gen. STAt. AnN. §§ 54-86d to -86e (West 2001); MASS. Gen. LAWs ANN. ch. 41, § 97D (West 2003). For a more comprehensive list of statutes, see Jonathan B. Mintz, The Remains of Privacy's Disclosure Tort: An Exploration of the Private Domain, 55 MD. L. REV. 425, 433 n.40 (1996).

24. See, e.g., Cal. Health \& SAfety Code $\S \S 199.20-.21$; Fla. Stat. AnN. $\$ 381.004$ (West 2002); Mich. Comp. Laws ANN. § 333.5133 (West 2001); N.Y. PUb. HeALTH LAW $\$ 2782$ (McKinney 2001). For a more comprehensive list of statutes, see Mintz, supra note 23, at 433-34 n.41.

25. See, e.g., Fla. Stat. Ann. § 390.0112; Mass. Gen. LaWs AnN. ch. 112, § 12S; Mich. COMP. LAWS ANN. § 333.17015. For a more comprehensive list of statutes, see Mintz, supra note 23 , at 434 n. 42 .

26. See, e.g., Colo. Rev. Stat. § 27-10-120 (2003); Conn. Gen. Stat. AnN. § 17a-451; Mass. Gen. Laws ANN. ch. 19, § 16; N.J. STAT. ANN. § 30:4-24.3 (West 1997). For a more comprehensive list of statutes, see Mintz, supra note 23, at 434 n.44. 
public policy. ${ }^{27}$ For example, Harry Kalven argues that the public disclosure tort is a failure and should be abolished. ${ }^{28}$ Diane Zimmerman contends that privacy is outweighed by society's "powerful countervailing interest in exchanges of accurate information about the private lives and characters of its citizenry." ${ }^{29}$ Richard Posner and Richard Epstein contend that the law should not protect against disclosures of discreditable information, since this information is useful to others in judging people, and concealment is tantamount to fraud. ${ }^{30}$ Solveig Singleton argues that "[t]hroughout history, people have generally been free to learn about one another in the course of business transactions and other day-to-day contracts. Restrictions that alter this default rule sweep a potentially enormous pool of facts and ideas out of the shared domain." ${ }^{31}$ Finally, Eugene Volokh has engaged in one of the most extensive attacks on disclosure protections, arguing that they are incompatible with freedom of speech. ${ }^{32}$

Privacy appears to conflict with the general mantra of the Information Age-that information should roam free. Disclosure protections, critics charge, promote a culture of secrecy rather than one of openness. Privacy impedes discourse, impairs autonomy in communication, and prevents accountability for one's conduct. Many people want to know if their neighbors are sex offenders, if their babysitters have a criminal past, if their sexual partners have a sexually transmitted disease, and if their spouses are being unfaithful.

27. See Randall P. Bezanson, The Right to Privacy Revisited: Privacy, News, and Social Change, 1890-1990, 80 CAL. L. REV. 1133, 1172-73 (1992) (arguing that privacy's "vindication through the common law privacy tort . . . has proven ineffective. . . [and] has become an anachronism"); John H. Fuson, Note, Protecting the Press from Privacy, 148 U. PA. L. REV. 629, 637 (1999) ("[I]t is impossible to draw a universal line in the sand ... that protects privacy entirely without unduly compromising other social values.").

28. Harry Kalven, Jr., Privacy in Tort Law-Were Warren and Brandeis Wrong?, 31 LAW \& CONTEMP. PROBS. 326 (Spring 1966).

29. Diane L. Zimmerman, Requiem for a Heavyweight: A Farewell to Warren and Brandeis's Privacy Tort, 68 CORNELL L. REV. 291, 341 (1983).

30. Richard Posner, ECONOMic ANAlysis of LAW 46, 660-63 (1998); see Richard A. Epstein, The Legal Regulation of Genetic Discrimination: Old Responses to New Technology, 74 B.U. L. REV. 1, 12 (1994) ("[W]hen a major change in personal or financial status is contemplated by another party, the white lies that make human interaction possible turn into frauds of a somewhat deeper dye.").

31. Solveig Singleton, Privacy Versus the First Amendment: A Skeptical Approach, 11 Fordham InTELl. PROP. MEDiA \& ENT. L.J. 97, 152 (2000).

32. Eugene Volokh, Freedom of Speech and Information Privacy: The Troubling Implications of a Right to Stop People from Speaking About You, 52 STAN. L. REV. 1049, 1090, 1095 (2000). 
Thus, privacy protections against disclosure, when analyzed in light of our longstanding tradition of protecting free speech and a free press, seem quite problematic.

Why should the law limit disclosures of true information, especially information people find interesting, entertaining, or important for understanding and judging other people? In this Article, I justify why the law should protect against disclosures of private information. Thus far, few commentators have attempted a thorough defense of protections against disclosure. In certain contexts, such protections have been defended, ${ }^{33}$ but much work remains to justify these protections systemically. Justifying privacy protections is difficult because in countless situations disclosures should be permitted. How can one determine which disclosures to restrict and which to permit?

The justifications for the law's intervention are nuanced and complex, but they are worth exploring. In a world of unprecedented information dissemination, with a staggering array of types of media and a profound number of media entities, the issue of why the law should protect against the disclosure of personal information is of paramount importance.

In this Article, Parts I and II develop a justification for protections against disclosure by engaging the central critiques of such protections. I classify the criticisms into two groups, which I label (1) "the free speech critique," and (2) "the judgment and trust critique."

33. Paul Schwartz has been the most notable defender of disclosure protections. Schwartz has defended protections against the disclosure of health and genetic information to employers and insurers. See Paul M. Schwartz, Privacy and the Economics of Personal Health Care Information, 76 TEX. L. REV. 1, 29 (1997) ("[G]enetic information may cause certain members of society to be transformed into a 'biological underclass."). Schwartz's article is a profound contribution to the debate, but his focus is narrow and he does not address the free speech critique. Schwartz has also defended the Fair Information Practices against Eugene Volokh's critique. Paul M. Schwartz, Free Speech vs. Information Privacy: Eugene Volokh's First Amendment Jurisprudence, 52 STAN. L. REV. 1559, 1560-64 (2000). The Fair Information Practices are a set of principles for the regulation of data originally proposed in the United States in 1973 and later developed internationally by the Organization for Economic Cooperation and Development in 1980. Schwartz's main argument is that the Fair Information Practices are not simply restrictions on the disclosure of personal data, but are rules that govern the access, use, and accuracy of information. Id. at 1561-62. Robert Post has also offered a very important and influential defense of the public disclosure tort, justifying it as promoting rules of civility. See Robert C. Post, The Social Foundations of Privacy: Community and Self in the Common Law Tort, 77 CAL. L. REV. 957, 959 (1989) ("[T]he tort . . safeguards rules of civility that in some significant measure constitute both individuals and community."). However, his article does not address the free speech critique. 
Part I discusses the free speech critique. According to this argument, protections against the disclosure of true personal information interfere with the First Amendment right to free speech. I argue that the existing free speech doctrine already contains the seeds for a viable approach toward permitting privacy protections. Privacy interests often do not conflict with the reasons for which society values free speech. In fact, privacy may serve these ends as well as or even better than does free speech. I conclude that speech of private concern is less valuable than speech of public concern and should be assigned less weight when being balanced against privacy protections.

The great difficulty, however, is determining how the law should distinguish between speech of public and private concern. Existing approaches include (1) deferring to the media, (2) looking to the status of the individual involved (e.g., whether the subject of the disclosure is a public or private figure), or (3) focusing on the nature of the information (e.g., whether it relates to public matters such as politics, or private matters such as health and sex). These prevailing approaches view disclosure in a black-and-white fashion: either information is of public concern and can be disclosed for any purpose, or it is of private concern and should be kept secret.

I argue that the prevailing approaches are deeply flawed. In view of this criticism, what is the best way to distinguish between private and public concerns? I suggest that the answer lies in an unlikely source-the law of evidence, which has much to teach the law of privacy. I do not refer to evidence law in its particulars, although I use some specific examples. Rather, I draw from some of evidence law's more general concepts - the way that it manages information. The law of evidence assesses the admissibility of information contextually rather than in the abstract. Evidence law links information to the context in which it is gathered and disseminated, and it looks to the purpose or the use of the data. Therefore, I argue that assessing whether a disclosure is of public or private concern should focus on the relationships in which information is transferred and the uses to which the information is put.

Part II focuses on a second group of criticisms-the judgment and trust critique. The judgment and trust critique views the free flow of personal information as valuable because it enables people to assess the reputation of others and to make important judgments about those with whom they associate. To the extent that disclosures do not involve people with whom one ordinarily interacts, these 
disclosures can provide insight into human nature and information about other people's lifestyles and attitudes. However, I argue that more information about people's private lives does not necessarily improve one's judgment about them. In fact, it may foster distorted and irrational judgments. Even some rational judgments about people are outweighed by privacy. As for aiding judgments about human nature, only certain forms of disclosure have an educative function. Additionally, I demonstrate how the harms of many disclosures can be avoided without sacrificing their benefits.

By engaging these critiques of privacy protections, I justify the law's safeguards against disclosures of personal information. Even in the current age, when information is king, sometimes less access to information is the soundest policy choice.

\section{THE FREE SPEECH CRITIQUE}

Protections against disclosure often come into conflict with the First Amendment right to free speech. The First Amendment provides that "Congress shall make no law ... abridging the freedom of speech, or of the press." ${ }^{34}$ The free speech critique contends that freedom of speech trumps privacy. As Thomas Emerson argues: "Any individual living among others is, by the very nature of society, subject to an enormous amount of comment, gossip, criticism and the like. His right to be left alone does not include any general right not to be talked about." ${ }^{35}$ Similarly, Eugene Volokh contends: "The difficulty is that the right to information privacy-my right to control your communication of personally identifiable information about me-is a right to have the government stop you from speaking about me." ${ }^{36}$ Volokh concludes that the First Amendment "generally bars the government from controlling the communication of information," and that "[w]hile privacy protection secured by contract is constitutionally sound, broader information privacy rules are not easily defensible under existing free speech law." ${ }^{37}$ Can disclosure protections be reconciled with the First Amendment?

In this Part, I argue that a workable balance between privacy and the First Amendment can be reached. The free speech critique is

34. U.S. CONST. amend. I.

35. Thomas I. EMERSON, THE SySTEM OF FrEEdOM OF EXPRESSION 556 (1970).

36. Volokh, supra note 32, at 1050-51.

37. Id.; see also Singleton, supra note 31, at 132-52 (surveying the issues that may arise from the conflict between privacy regulation and the First Amendment). 
quite formidable, and it cannot be readily dismissed. In the end, disclosure restrictions can withstand the critique, but it is a qualified and nuanced victory. I also aim to keep my argument tethered to existing Supreme Court jurisprudence. The Court has yet to address squarely the issue of whether many forms of disclosure restriction are constitutional. Nevertheless, there is support in the Court's existing doctrine for the constitutionality of many disclosure restrictions, although there is also support for proponents of the free speech critique. This is why my argument is not exclusively doctrinal; it is also normative, as I aim to describe the way in which existing doctrine should develop. In taking a normative stance, however, my goal is not to make a radical break with the existing law, but to illustrate how existing law could develop privacy protections while maintaining fidelity to established free speech doctrine.

Broadly, this Part proceeds as follows. Section A discusses two strands of the free speech critique-absolutism and balancing. For a free speech absolutist, the only way to support privacy protections is to argue that they do not infringe upon "speech." This approach ends up being less open and honest than a balancing approach. Under a balancing approach, the free speech critique argues that speech has a presumptively high value. I argue that not all speech is of equal value, and speech of private concern is less valuable than speech of public concern.

Section B argues that privacy interests often outweigh speech about private matters. Privacy fares well in the balance under each of the three predominant theories for the value of free speech.

Section $\mathrm{C}$ addresses the difficult issue of distinguishing between speech of public concern and speech of private concern. Traditionally, the law has drawn this distinction by deferring to the media, focusing on the status of the individual as either a public or private figure, or examining the nature of the information at issue. However, a better approach would draw insights from evidence law by focusing on the relationships in which information is transferred and the uses to which it is put.

\section{A. Absolutism vs. Balancing}

At the most general level, there are two approaches to assessing whether a particular law or regulation affecting speech violates the First Amendment. Absolutists contend that if a particular use of information constitutes speech, the law cannot regulate or prohibit its 
disclosure because the value of free speech is absolute. In contrast, balancers assign a value to free speech and weigh it against competing interests. ${ }^{38}$ A regulation violates the First Amendment if it is outweighed in the balancing. In this Section, I critique the absolutist position and endorse a balancing approach. However, even under a balancing approach, the free speech critique remains quite powerful, and it strives to apply strict scrutiny to most privacy protections that implicate speech. I argue that privacy protections should be reviewed under a less stringent form of scrutiny because they implicate speech of private concern, which has less value than speech of public concern.

1. Absolutism. The absolutist position toward the First Amendment was most famously applied by Justice Hugo Black. ${ }^{39}$ Black argued that the First Amendment is an "unequivocal command that there shall be no abridgment of the rights of free speech and assembly." ${ }^{40}$ Likewise, Jed Rubenfeld asserts that "there are certain First Amendment absolutes, which stand up regardless of any balancing of interests. ${ }^{, 41}$ If one adopts such an absolutist position toward free speech, privacy protections become difficult to defend. No matter how valuable privacy protections might be, the First Amendment's protection of free speech remains absolute.

But there is a way for the absolutist to accept privacy protections. One can escape First Amendment protection by contending that certain types of personal information or uses of data are not speech. When analyzing whether speech is protected by the First Amendment, the Supreme Court initially asks whether "speech" is implicated. What constitutes speech is a difficult question, as many expressive activities are a combination of conduct and speech, such as

38. See T. Alexander Aleinikoff, Constitutional Law in the Age of Balancing, 96 YALE L.J. 943, 945 (1987) (“[A] 'balancing opinion' ... analyzes a constitutional question by identifying interests implicated by the case and reaches a decision ... by explicitly or implicitly assigning values to the identified interests.").

39. Laurent B. Frantz, The First Amendment in the Balance, 71 YALE L.J. 1424, 1424 (1962); Alexander Meiklejohn, The First Amendment Is an Absolute, 1961 SuP. CT. REV. 245, 246.

40. Konigsberg v. State Bar of Cal., 366 U.S. 36, 61, 63 (1961) (Black, J., dissenting); see also Hugo L. Black, The Bill of Rights, 35 N.Y.U. L. REV. 865, 881 (1960) ("Our First Amendment was a bold effort to ... establish a country with no legal restrictions of any kind upon the subjects people could investigate, discuss and deny.").

41. Jed Rubenfeld, The First Amendment's Purpose, 53 StAn. L. REV. 767, 770 (2001). 
wearing an armband, ${ }^{42}$ burning a flag, ${ }^{43}$ and dancing in the nude. ${ }^{44}$ For the absolutist, certain categories of expression are not considered to be speech at all, such as shouting fire in a crowded theater, obscenity, "fighting words," ${ }^{46}$ and child pornography. ${ }^{47}$ If speech is not involved, then there is no need to take the First Amendment into account. $^{48}$

Is personal information speech? Although a news story about a person clearly involves speech, commentators debate whether the transfer of databases of personal information also qualifies as speech. Some commentators contend that such databases are transferred as a "good," not as "speech." When companies "rent" their databases of personal information to other companies, credit reporting agencies issue reports about people's financial condition, and marketers collect and use personal information, these uses resemble business transactions, such as the sale of a commodity, rather than an act of expression. As Julie Cohen argues: "personally-identified data is not collected, used or sold for its expressive content at all; it is a tool for processing people, not a vehicle for injecting communication into the "marketplace of ideas." "

The data is itself the subject matter of the transaction-the "goods" exchanged. And, as distinct from news or literature, or from reports of scientific research exchanged among colleagues, it isn't purchased to be "read." Rather, it is purchased to serve a fundamentally different sort of function-that of categorizing and segmenting a customer base. $^{50}$

On the other hand, some commentators argue that the transfer of databases of personal information can be thought of as speech-it

42. See Tinker v. Des Moines Indep. Cmty. Sch. Dist., 393 U.S. 503, 514 (1969) (holding that wearing an armband to protest the Vietnam war and advocate a truce was speech).

43. Texas v. Johnson, 491 U.S. 397, 406 (1989).

44. Barnes v. Glen Theatre, Inc., 501 U.S. 560, 570-71 (1991) (nude dancing is speech).

45. Miller v. California, 413 U.S. 15, 36 (1973).

46. Chaplinksy v. New Hampshire, 315 U.S. 568, 572 (1942).

47. New York v. Ferber, 458 U.S. 747, 764 (1982).

48. The argument that certain uses of information are not speech is not exclusively an absolutist position. Balancers can also argue that certain information is not speech. In contrast to absolutists, however, for balancers the designation of information as "speech" does not immediately end the inquiry; speech must be balanced against the interest in restricting it.

49. Julie E. Cohen, Examined Lives: Informational Privacy and the Subject as Object, 52 STAN. L. REV. 1373, 1414 (2000).

50. Id. at $1417-18$. 
informs another entity about potential new customers. Under this view, one company is saying to another: "Take a look at John Doe. Here is relevant information about why he might be a good customer. These are his interests." Of course, with massive databases of personal information, the above statement is being made en masse about millions of individuals, but it is still communicating something. ${ }^{51}$

Volokh argues that databases of personal information and credit reports are speech of significant importance, even when distributed en masse. Information in databases can help people "find out with whom they should do business." ${ }^{, 2}$ In addition, disclosures by credit reporting agencies assist people and companies when deciding whether to give a person a loan or credit: "[I]t is no less speech when a credit bureau sends credit information to a business. The owners and managers of a credit bureau are communicating information to decisionmakers, such as loan officers, at the recipient business." ${ }^{53}$ Although credit reports are a lucrative "product" produced by credit reporting agencies, they can be readily classified as a form of speech, for they are telling creditors about the reputations of people.

There are no easy analytic distinctions as to what is or is not "speech." The "essence" of information is neither a good, nor is it speech, for information can be used in ways that make it akin to either one. It is the use of the information that determines what information is, not anything inherent in the information itself. If I sell you a book, I have engaged in a commercial transaction. I sold the book as a good. However, the book is also expressing something. Even though books are sold as goods, the government cannot pass a law restricting the topics of what books can be sold.

"Speech" is very difficult to define. Volokh appears to view all information dissemination that is communicative as speech. Under Volokh's view, therefore, most forms of information dissemination would be entitled to equal First Amendment protection:

Though the Court has often said in dictum that political speech or public-issue speech is on the "highest rung" of constitutional protection, it has never held that there's any general exception for speech on matters of "private concern." Political speech, scientific

51. See, e.g., Singleton, supra note 31, at 152 ("Throughout history, people have generally been free to learn about one another in the course of business transactions and other day-to-day contacts.").

52. Volokh, supra note 32, at 1094.

53. Id. at $1083-84$. 
speech, art, entertainment, consumer product reviews, and speech on matters of private concern are thus all doctrinally entitled to the same level of high constitutional protection, restrictable only through laws that pass strict scrutiny. ${ }^{54}$

However, Volokh's view would lead to severe conflicts with much modern regulation. Full First Amendment protection would apply to statements about a company's earnings and other information regulated by the SEC, insider trading, quid pro quo sexual harassment, fraudulent statements, perjury, bribery, blackmail, extortion, conspiracy, and so on. One could neatly exclude these examples from the category of speech, eliminating the necessity for First Amendment analysis. Although this seems the easiest approach, it is conceptually sloppy or even dishonest absent a meaningful way to argue that these examples do not involve communication. I contend that these examples of highly regulated forms of communication have not received the full rigor of standard First Amendment analysis because of policy considerations. Categorizing them as nonspeech conceals these policy considerations under the façade of an analytical distinction that thus far has not been persuasively articulated.

I am not eschewing all attempts at categorization between speech and nonspeech. To do so would make the First Amendment applicable to virtually anything that is expressive or communicative. Still, the distinction as currently constituted hides its ideological character.

Categories are artificial constructions and must be evaluated by their usefulness. Dealing with privacy issues by categorizing personal information as nonspeech is undesirable because it cloaks the real normative reasons for why society wants to permit greater regulation of certain communicative activity. Rather than focusing on distinguishing between speech and nonspeech, the determination about what forms of information to regulate should center on policy considerations. These policy considerations should turn on the uses of the information rather than on notions about the inherent nature of the information.

2. Balancing. In contrast to absolutism, balancing does not view the value of free speech as absolute. The value of free speech is weighed against the benefits of speech restrictions. Although the

54. Id. 
debate between absolutism and balancing has generated a substantial body of literature, ${ }^{55}$ the balancing approach has largely prevailed. Even Aleinikoff, one of the principal modern skeptics of balancing, recognizes that balancing "has become widespread, if not dominant, over the last four decades." " Accordingly, I address the remainder of this Article to arguments involving balancing.

Proponents of the free speech critique have a strong argument under a balancing approach. Because free speech is inscribed in the Constitution, it has a presumptively high value. ${ }^{57}$ Americans have a strong commitment to freedom of speech, deemed fundamental to a free and democratic society. Therefore, even in a balancing approach, the free speech critique contends that free speech must be valued very highly, and it should trump most nonconstitutional interests.

Indeed, under the Court's current balancing approach, constitutional rights such as free speech weigh heavily. When an expressive activity is deemed speech, the Court examines the nature of the restriction and "balances" it against the government interest supporting the restriction. Of course, "balancing" does not quite capture what the Court does when it determines whether a statute is viable under the First Amendment. ${ }^{58}$ The Court examines the law

55. Despite its dominance in constitutional jurisprudence, balancing has received ample criticism. According to T. Alexander Aleinikoff, the Court has difficulty in "translat[ing] the value of interests into a common currency for comparison." Aleinikoff, supra note 38, at 973. Frequently, the Court "adopts a seat-of-the-pants approach, freely speculating on the real world consequences of particular rules." Id. at 974. Although balancing can be performed in a shoddy manner, the approach has many virtues. As I have previously argued, "[w]ith its greater focus on empirical evidence in issues of constitutional interpretation, [balancing] brings law more in tune with contemporary science, social science, economics, and other fields of human knowledge." Daniel J. Solove, The Darkest Domain: Deference, Judicial Review, and the Bill of Rights, 84 IOWA L. REV. 941, 1021 (1999).

56. Aleinikoff, supra note 38 , at 943.

57. Several scholars have attempted to translate the absolutist position into instrumental terms. For example, Peter Edelman contends that "[a]bsolutists also engage in balancing of interests, but the process occurs before they commit pen to paper." Peter B. Edelman, Free Press v. Privacy: Haunted by the Ghost of Justice Black, 68 TEX. L. REV. 1195, 1213 (1990); see also Charles L. Black, Jr., Mr. Justice Black, the Supreme Court, and the Bill of Rights, HARPER's, Feb. 1961, at 63, reprinted in CHARlEs L. BLACK, JR., THE OCCASIONS OF JUSTICE: ESSAYS MOSTLY ON LAW 89, 94-96 (1963) (“[E]very bit of 'balancing' that could possibly enter into the qualification of these rights can enter just as well into their definition as into a process of denying them 'absolute' force after they are defined."). Despite these attempts at translation, there are fundamental differences between absolutism and balancing. Absolutism is a deontological position, and those who argue that even absolutists "balance" are in essence contending that the absolutists cheat on their own theoretical foundations.

58. See, e.g., Richard H. Pildes, Avoiding Balancing: The Role of Exclusionary Reasons in Constitutional Law, 45 HASTINGS L.J. 711, 711-12 (1994) ("Contrary to the connotations 
under a level of constitutional "scrutiny." Under strict scrutiny, to "outweigh" a First Amendment interest, a law must be the "least restrictive means" to achieve a "compelling" government interest. ${ }^{59}$ Under intermediate scrutiny, a law must be narrowly tailored to a "substantial government interest."

Thus, the constitutional right and government interest are not simply placed on a scale and weighed; rather, certain thresholds are required for the weight of the government interest. The result is that, even if a constitutional right has a relatively low value, the value of the government interest must be more than marginally higher to survive constitutional scrutiny. Thus, strict scrutiny, the highest level of scrutiny, establishes a high minimum threshold for the value of free speech. Accordingly, speech restrictions rarely outweigh speech under strict scrutiny. Indeed, very few restrictions survive strict scrutiny, which has been referred to as " "strict' in theory and fatal in fact.","1

When deciding what level of scrutiny to apply, courts look to whether the regulation of speech is content-based or content-neutral. A content-based regulation restricts speech based on its content-the particular message or viewpoint being expressed. By contrast, a content-neutral law regulates speech no matter what viewpoint the speaker espouses; examples include restrictions on the time, place, or manner of speech. For example, a noise ordinance regulates all speech regardless of what is being said. Subject to certain exceptions, content-based restrictions are accorded strict scrutiny, ${ }^{62}$ and contentneutral restrictions are reviewed under intermediate scrutiny. The

suggested by the balancing metaphor, constitutional adjudication is often a qualitative process, not a quantitative one. It is about defining the kinds of reasons that are impermissible justifications for state action in different spheres.").

59. See, e.g., Sable Communications, Inc. v. FCC, 492 U.S. 115, 126 (1989) (striking down a ban on indecent dial-a-porn services under strict scrutiny).

60. United States v. O'Brien, 391 U.S. 367, 377 (1968) (upholding a restriction on burning draft registration certificates under intermediate scrutiny). For more background on the constitutional scrutiny tests, see Solove, supra note 55, at 954.

61. Gerald Gunther, The Supreme Court, 1971 Term-Foreword: In Search of Evolving Doctrine on a Changing Court: A Model for a Newer Equal Protection, 86 HARV. L. REV. 1, 8 (1972).

62. The most notable exception is the secondary effects doctrine. If the government regulates a particular form of speech because of certain secondary effects, the Court has held that this is not a content-based regulation even though it singles out particular forms of speech based on content. See, e.g., City of Renton v. Playtime Theatres, 475 U.S. 41, 47-48 (1986) (finding that an ordinance restricting the location of adult movie theaters was consistent with the concept of a content-neutral regulation because its purpose was to prevent crime and the other secondary effects of such theaters). 
free speech critique argues that privacy protections against disclosure are content-based restrictions because they single out certain messages invasive of privacy. Hence, they must be subject to strict scrutiny.

If speech has a very high value, then protections against disclosure would be subject to the highest form of constitutional scrutiny, and would have to promote interests with an exceedingly high value to survive. Moreover, the law must be the "least restrictive means" to achieve the government interest - a very difficult standard to satisfy. Volokh argues that privacy interests rarely rise to a level worthy of withstanding strict scrutiny: "Why should the harm to my child and my family stemming from the child's exposure to online indecency remain unprevented ... when the indignity that someone feels from having his shopping habits communicated by one business to another justifies a speech restriction?" ${ }^{63}$ Volokh equates both types of speech, and would protect both.

Privacy has a high value, as I argue in Section B (as well as in Part II), but if the law assigns a default high value to all forms of speech, the balancing will be quite difficult for privacy. I contend that not all forms of speech have a high value. Some forms of speech have a lower value and are more readily outweighed by privacy interests. For example, Volokh's question equates speech constituting online indecency with speech between businesses about a person's shopping habits. However, these types of speech are quite different. Censoring indecent speech that a child might encounter online creates a difficult problem-how to protect the child yet also preserve the speech for adults. This problem often does not emerge in the transfer of personal information between businesses. A law prohibiting indecent speech is likely to discriminate against certain viewpoints and to encompass important political, artistic, and literary expression. In contrast, it is unclear whether restricting the transfer of shopping data between businesses will have similar potential downstream effects. Only in a very formalistic sense can these two types of speech be viewed as equivalent.

The conclusion that all speech does not have equal value runs counter to the "neutrality principle," which has long been a cornerstone of traditional liberalism. According to the neutrality principle, the government must maintain neutrality as to different

63. Volokh, supra note 32, at 1104. 
conceptions of the good. ${ }^{64}$ In the context of free speech, the neutrality principle mandates that the government must avoid favoritism or bias toward particular messages. ${ }^{65}$ All speech must therefore be valued equally. Allowing the government to ascribe different values to different messages gives too much power to government officials to pick and choose the messages they approve. This leads to discrimination against unpopular ideas and the danger that minority viewpoints will not be valued sufficiently.

Useful as neutrality may seem, however, it is a fiction. ${ }^{66}$ As pragmatists persuasively argue, there is no way to perceive facts outside of a particular context, and perception is infused with partiality. ${ }^{67}$ According to John Dewey, "[a]ll knowing and effort to know starts from some belief, some received and asserted meaning which is a deposit of prior experience, personal and communal." ${ }^{\circ 8}$ Building upon these ideas, legal realists contend that judges are not oracles of the law, and they cannot magically eliminate all of their own preconceptions and biases from their decisions. ${ }^{69}$ No matter the effort, one cannot reach a position of pure neutrality.

64. See, e.g., J.M. Balkin, Some Realism About Pluralism: Legal Realist Approaches to the First Amendment, 1990 DUKE L.J. 375, 392 (critiquing the traditional liberal view "requiring neutrality with respect to competing visions of the good").

65. See Police Dep’t or Chicago v. Mosley, 408 U.S. 92, 95 (1972) (“[A]bove all else, the First Amendment means that government has no power to restrict expression because of its message, its ideas, its subject matter, or its content."); EMERSON, supra note 35, at 326 (explaining that "value judgments concerned with the content of expression" are "foreclosed... by the basic theory of the First Amendment"). For a good critique of the neutrality principle, see CASS R. Sunstein, Democracy AND the Problem of FreE SPeECh (1993).

66. See, e.g., Stanley Fish, There's No Such Thing as Free SPeECH AND It's a Good THING, ToO 11-16 (1994) (discussing nonconsequentialist positions concerning free speech and their tendency to shift into consequentialism); $i d$. at 15 ("Short of an absolutely absolutist position (which no one holds or defends), a line must be drawn between protected speech and speech that might in some circumstances be regulated, and that line will always reflect a political decision to [value] some kinds of verbal behavior and devalue others."); Balkin, supra note 64, at 396 ("[T] he ideal of eliminating content based regulation was never realized in practice.").

67. John DEWEY, EXPERIENCE AND NATURE (1925), reprinted in 1 JOHN DEWEY: THE LATER WORKs, 1925-1953, at 107 (Jo Ann Boydston ed., 1987); see also Brian Z. Tamanaha, Pragmatism in U.S. Legal Theory: Its Application to Normative Jurisprudence, Sociolegal Studies, and the Fact-Value Distinction, 41 AM. J. JuRIS. 315, 343-53 (1996) (discussing the application of pragmatism and the inevitability of a context- and perspective-dependent perception of facts).

68. DEWEY, supra note 67, at 320.

69. See generally Brian Leiter, Rethinking Legal Realism: Toward a Naturalized Jurisprudence, 76 TEX. L. REV. 267 (1997) (outlining the "Core Claims" and "Received View" of realism and discussing the impact of realism on jurisprudence). 
Under current Supreme Court doctrine, not all forms of speech are equally valued. ${ }^{70}$ For example, in Chaplinsky v. New Hampshire, ${ }^{71}$ the Court noted that certain categories of speech, such as obscenity and "fighting words," "are of such slight social value as a step to truth that any benefit that may be derived from them is clearly outweighed by the social interest in order and morality.", Commercial speech also occupies a "subordinate position in the scale of First Amendment values." ${ }^{, 3}$ Although this differential valuation is not a bad thing, the fact that pure neutrality is neither possible nor optimal does not mean that the quest for neutrality should be abandoned.

Scholars often view neutrality and balancing as antithetical positions; one must strive to remain completely neutral or balance each speech act individually. For example, Jed Rubenfeld makes a straw man out of the balancing position, and he rejects any classification of speech into "high" and "low" value categories. ${ }^{74}$ Rubenfeld raises the example of racist speech, arguing that although "[i]t is unquestionably protected by the First Amendment[,] ... . how can anyone purport to say with confidence that its 'value' exceeds its costs?" ${ }^{75}$ Rubenfeld's argument attacks balancers who would contend that racist speech should receive First Amendment protection. How can the ad hoc balancer justify such protection based on a cost-benefit analysis? Rubenfeld concludes that "the cost-benefit approach offers no adequate explanation of the categorical First Amendment principle against viewpoint discrimination."

A balancer, however, can conclude that neutrality is still worth pursuing to some degree, even if it cannot be perfectly achieved and

70. See, e.g., Dun \& Bradstreet, Inc. v. Greenmoss Builders, Inc., 472 U.S. 749, 758 (1985) ("We have long recognized that not all speech is of equal First Amendment importance."). Cass Sunstein has argued that a workable system of free speech depends upon "making distinctions between low and high value speech, however difficult and unpleasant that task may be." Cass R. Sunstein, Low Value Speech Revisited, 83 Nw. U. L. REV. 555, 557 (1989). For a critique of the high/low value speech classification, see Larry Alexander, Low Value Speech, 83 Nw. U. L. REV. 547 (1989). See also Susan M. Gilles, All Truths Are Equal but Are Some Truths More Equal Than Others?, 41 CASE W. RES. L. REV. 725, 726 (1991) (arguing that it is dangerous "for the Court to select among truths, declaring some 'valuable' (and thus, worthy of First Amendment protection) and branding others 'valueless' (meriting little or perhaps no protection)").

71. 315 U.S. 568 (1942).

72. Id. at 572 .

73. Ohralik v. Ohio State Bar Ass'n, 436 U.S. 447, 456 (1978).

74. Rubenfeld, supra note 41, at 822-26.

75. Id. at 825 .

76. Id. 
even if it is not worth pursuing all the time. In the context of free speech, the law should neither reject nor embrace neutrality wholesale. It is appropriate to ascribe a different value to different forms of speech, but only up to a point. Rubenfeld wrongly assumes that the balancer must assess the value of protecting each speech act by focusing myopically on the particular value of each speech act. But a pragmatic analysis would also consider the systemic effects of the particular case. ${ }^{77}$ An appropriate balance would consider the downstream effects of a decision and the importance of striving toward neutrality for particular forms of speech.

I propose that speech of private concern should be accorded less protection than speech of public concern. The Supreme Court has endorsed this view to a limited extent, in that the Court does value different forms of speech differently. ${ }^{78}$ In Dun \& Bradstreet, Inc. v. Greenmoss Builders, Inc., ${ }^{79}$ the plurality concluded that "not all speech is of equal First Amendment importance. It is speech on 'matters of public concern' that is 'at the heart of the First Amendment's protection'. ... In contrast, speech on matters of purely private concern is of less First Amendment concern." Regarding the specific facts of the case, the Court held that credit reports should receive a low value under First Amendment analysis because they do not concern a "public issue," and because they constitute "speech solely in the individual interest of the speaker and its specific business audience." Although Dun \& Bradstreet was a defamation case, it should have wider applicability. Extending its reasoning to personal information more generally, the case suggests that speech of private concern is less valuable than speech of public concern because it fails to promote the interests of free speech as

77. See Richard A. Posner, LAw, Pragmatism, And Democracy 69 (2003) (contending that decision according to rule, rather than ad hoc, can be pragmatic "because the loss from ignoring the consequences in the particular case must be balanced against the gain from simplifying inquiry, minimizing judicial discretion, increasing the transparency of law, and making legal obligation more definite").

78. See, e.g., STEVEN H. SHIFFrin, THE FIRST AMENDMENT, DEMOCRACY, AND ROMANCE 10-39 (1990) ("[G]overnment hostility to particular points of view is often acceptable, and evaluations of the value of speech run through the fabric of first amendment law."); Geoffrey R. Stone, Restrictions of Speech Because of Its Content: The Peculiar Case of Subject-Matter Restrictions, 46 U. CHI. L. REV. 81, 84-100 (1978) (discussing the holdings and reasoning of the Court in seven cases addressing subject-matter restrictions on speech).

79. 472 U.S. 749 (1985).

80. Id. at 758-59 (footnote omitted) (quoting First Nat'l Bank of Boston v. Bellotti, 435 U.S. 765, $776(1978))$.

81. Id. at 762 . 
strongly as speech of public concern. This does not mean that speech of private concern will lose out in the balancing; it simply means that such speech will receive less weight and will more likely be subject to regulation. Accordingly, in contrast to Volokh, who contends that the First Amendment mandates strict scrutiny for most privacy protections, I argue that a less stringent form of scrutiny should be used.

The Court has made overtures toward such an approach in its privacy law jurisprudence. In numerous cases, the Court has articulated a public and private concern distinction, and it has applied the First Amendment to curtail restrictions on speech of public concern without answering questions about limiting speech of private concern. In Smith v. Daily Mail Publishing Co. ${ }^{82}$ the Court held that "if a newspaper lawfully obtains truthful information about a matter of public significance then state officials may not constitutionally punish publication of the information, absent a need to further a state interest of the highest order." ${ }^{, 3}$ In the Court's latest case to touch upon these issues, Bartnicki v. Vopper ${ }^{84}$ it held that "privacy concerns give way when balanced against the interest in publishing matters of public importance." ${ }^{, 5}$ In case after case the Court has refused to address what, if any, constitutional scrutiny would apply to matters of private concern. In Florida Star v. B.J.F., ${ }^{86}$ the Court rejected the "invitation to hold broadly that truthful publication may never be punished consistent with the First Amendment. Our cases have carefully eschewed reaching this ultimate question." ${ }^{87}$ As recently as Bartnicki, the Court noted its "repeated refusal to answer categorically whether truthful publication may ever be punished consistent with the First Amendment." ${ }^{88}$ The Court appears to view the public and private concern distinction as having significance because it has used this distinction to limit the application of heightened scrutiny to restrictions on speech of public concern. Although it has yet to address the private concern side of the

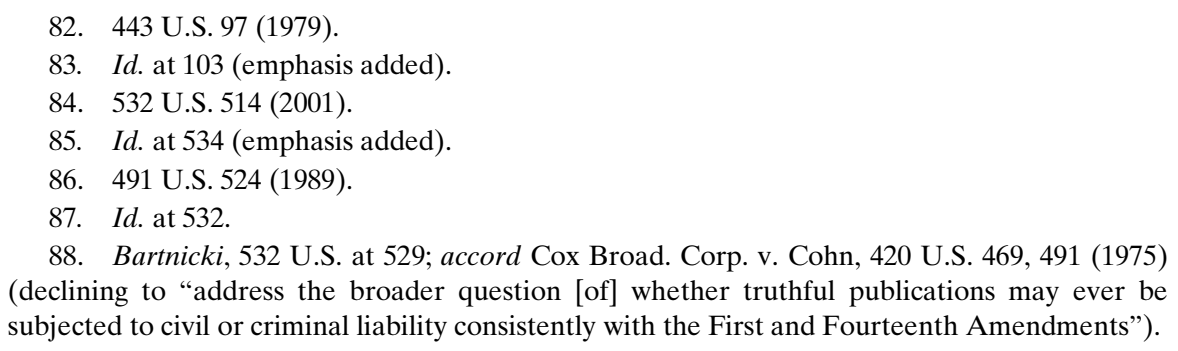
(declining to "address the broader question [of] whether truthful publications may ever be subjected to civil or criminal liability consistently with the First and Fourteenth Amendments"). 
distinction, the Court appears to be heading in the direction that I advocate.

Nevertheless, such an approach must be squared with R.A.V.v. City of St. Paul, ${ }^{89}$ in which the Court held that the government cannot engage in "further content discrimination" when regulating low value categories of speech. ${ }^{90}$ For example, "the government may proscribe libel; but it may not make the further content discrimination of proscribing only libel critical of the government."91 The Court's concern is to avoid viewpoint discrimination. Thus, content-based distinctions can be made "[w]hen the basis for the content discrimination consists entirely of the very reason the entire class of speech at issue is proscribable" because "no significant danger of idea or viewpoint discrimination exists." ${ }^{92}$ To the extent that the public and private concern distinction is embodied in Supreme Court jurisprudence, speech of private concern is a "class of speech" similar to other classes of speech such as libel and commercial speech. R.A.V. would not allow privacy protections to function as a proxy for regulating particular viewpoints. Rather, R.A.V. would permit only those privacy protections justified by the reasons that speech of private concern is valued less than speech of public concern. It is to this issue that I now turn.

\section{B. Balancing Free Speech and Privacy}

Thus far, I have argued that balancing is the most workable approach for reconciling the tension between privacy protections and free speech. Under such an approach, however, privacy protections should not be reviewed under strict scrutiny, because speech of private concern should be valued less than speech of public concern. Thus, a lesser form of scrutiny should be employed. In this Section, I explain why. The answer lies in the reasons why society values free speech, the extent to which speech of private concern furthers these interests, and the contributions of privacy protections toward advancing these interests.

Numerous theories have been proposed to explain why free speech is valuable. In this Section, I explore the most popular theories: (1) individual autonomy, (2) democratic self-governance,

\footnotetext{
89. 505 U.S. 377 (1992).

90. Id. at 384 .

91. Id.

92. Id. at 388 .
} 
and (3) the marketplace of ideas. In discussing these theories under separate headings, I do not intend to imply that they are mutually exclusive. ${ }^{93}$ Free speech can be valued for a number of reasons. I contend that under each theory, speech of private concern does not strongly further the interests justifying free speech. If society wants to promote the interests justifying free speech, a vigorous protection of speech at the expense of privacy can, in fact, impair these interests.

1. Individual Autonomy. One of the most frequently articulated rationales for the value of free speech is that it promotes individual autonomy. ${ }^{94}$ As one commentator observes, the "value of free expression ... rests on its deep relation to self-respect arising from autonomous self-determination." ${ }^{95}$ The disclosure of personal information about others certainly falls within the autonomy of the speaker. Respect for autonomy requires recognition of strong rights of self-expression. Disclosure protections thus impair the autonomy of speakers who desire to speak about others. Additionally, free speech can be justified in terms of the autonomy of the listener. ${ }^{96}$ Under this view, free speech protects people's freedom of information consumption. Disclosure protections prevent people from hearing information that they want to know.

However, the autonomy justification cuts both ways in the context of privacy protections against disclosures of personal information. As Sean Scott observes, "the right to privacy and the First Amendment both serve the same interest in individual

93. See, e.g., Thomas I. Emerson, First Amendment Doctrine and the Burger Court, 68 CAL. L. REV. 422, 423 (1980) (discussing the interdependence of the theories concerning the value of the First Amendment).

94. See, e.g., C. Edwin Baker, Scope of the First Amendment Freedom of Speech, 25 UCLA L. REV. 964, 990-1009 (1978) (explaining three theoretical models addressing the scope of First Amendment speech protection); Richard H. Fallon, Jr., Two Senses of Autonomy, 46 STAN. L. REV. 875 (1994) (asserting and applying two theories relating to the autonomy-based First Amendment doctrine); Martin H. Redish, The Value of Free Speech, 130 U. PA. L. REV. 591, 593 (1982) ("[F]ree speech ultimately serves only one true value, which I have labeled 'individual self-realization."'); Thomas Scanlon, A Theory of Freedom of Expression, 1 PHIL. \& PUB. AFF. 204, 213-18 (1972) (asserting that the underlying theory of free expression is John Stuart Mill's principle that actions may be justified if they prevent harms); David A. Strauss, Persuasion, Autonomy, and Freedom of Expression, 91 Colum. L. REV. 334, 353-60 (1991) (arguing that the persuasion principle can be defended on autonomy grounds because violating the principle interferes with a person's control over her reasoning processes).

95. David A.J. Richards, Free Speech and Obscenity Law: Toward a Moral Theory of the First Amendment, 123 U. PA. L. REV. 45, 62 (1974).

96. See SUNSTEIN, supra note 65, at 139 (distinguishing between speaker and listener autonomy). 
autonomy." ${ }^{97}$ The disclosure of personal information can severely inhibit a person's autonomy and self-development. ${ }^{98}$ Julie Cohen notes that "[a] realm of autonomous, unmonitored choice... promotes a vital diversity of speech and behavior," privacy "threatens not only to chill the expression of eccentric individuality, but also, gradually, to dampen the force of our aspirations to it." 100

The risk of disclosure can inhibit practices that may engender social reprobation. ${ }^{101}$ Satisfaction of a person's preference to engage in an activity has a positive value unless that activity is socially detrimental. Without protection against disclosure, the person might not engage in that activity. ${ }^{102}$ Fear of disclosure also inhibits people from exploring their preferences. ${ }^{103}$

Privacy permits individuals to contemplate and discuss political change, create counterculture, or engage in a meaningful critique of society. Privacy also enables creative expression that is often not possible within the constraints of public life. ${ }^{104}$ People have the opportunity to develop their views, political opinions, and artistic expressions without having such information prematurely leaked to the world, where harsh judgments and public opprobrium might crush them. Growth and development require experimentation and the opportunity to alter one's opinions before making them public. ${ }^{105}$ Privacy allows people to speak anonymously, encouraging robust

97. Sean M. Scott, The Hidden First Amendment Values of Privacy, 71 WASH. L. REV. 683, 723 (1996).

98. See Paul M. Schwartz, Privacy and Democracy in Cyberspace, 52 VAND. L. REV. 1609, 1665 (1999) (noting that privacy shapes "the extent to which certain actions or expressions of identity are encouraged or discouraged").

99. Cohen, supra note 49 , at 1425 .

100. Id. at 1426; see also ANITA L. AlLEN, UneAsy ACCESS: PRIVACY FOR WOMEN IN A FREE SOCIETY 44 (1988) ("The value of privacy is, in part, that it can enable moral persons to be self-determining individuals."); Ruth Gavison, Privacy and the Limits of Law, 89 YALE L.J. 421, 455 (1980) ("Privacy is also essential to democratic government because it fosters and encourages the moral autonomy of the citizen, a central requirement of a democracy.").

101. Richard S. Murphy, Property Rights in Personal Information: An Economic Defense of Privacy, 84 GEO. L.J. 2381, 2397 (1996).

102. Id. at 2398 .

103. Id. at 2397-98.

104. Alan F. Westin, PRIVACY AND FreEdom 37 (1967).

105. See id. at 33-34 ("Such independence [in thought and views] requires time for sheltered experimentation and testing of ideas, for preparation and practice in thought and conduct, without fear of ridicule or penalty, and for the opportunity to alter opinions before making them public.”). 
communication without fear of community reprisal. As Cohen points out, privacy also facilitates the reading and consumption of ideas. ${ }^{106}$ All of these activities are central to autonomy and self-determination.

If the interest of the speaker or listener is defined in terms of self-determination and autonomy, the interest of the harmed individual can be conceptualized in similar terms - as an assault on self-determination and autonomy. There is no clear reason why the autonomy of speakers or listeners should prevail over that of the harmed individuals.

One could argue that free speech protects autonomy more than privacy does, because free speech promotes the interests not only of the speaker but also of all who listen to the message. Under this view, privacy only protects the autonomy of the injured individual. This argument, however, understands the interest protected by privacy too narrowly. Just as the protection of speech has implications for all speakers and all listeners, privacy protection reaches beyond the specific individual whose privacy is involved in a given case. It protects everyone. Therefore, it is difficult to say whether free speech or privacy promotes more autonomy; both further autonomy, just in different ways and in different aspects of life.

2. Democratic Self-Governance. Another theory of free speech locates its value not in its protection of the individual, but in its furtherance of democratic self-governance. ${ }^{107}$ As Justice Brandeis famously observed in Whitney $v$. California: ${ }^{108}$

[W]ithout free speech and assembly[,] discussion would be futile; . . . with them, discussion affords ordinarily adequate protection against the dissemination of noxious doctrine; . . . the greatest menace to freedom is an inert people; ... public discussion is a political duty; and ... this should be a fundamental principle of the American government. ${ }^{109}$

106. Julie E. Cohen, A Right to Read Anonymously: A Closer Look at "Copyright Management" in Cyberspace, 28 CONN. L. REV. 981, 1012-13 (1996).

107. See, e.g., Jason Mazzone, Speech and Reciprocity: A Theory of the First Amendment, 34 ConN. L. REV. 405, 412-17 (2002) (noting that free speech enables citizens to engage in informed deliberation and to make wise choices in the process of self-governance).

108. 274 U.S. 357 (1927).

109. Id. at 375 (Brandeis, J., concurring). 
Similarly, Alexander Meiklejohn views the value of free speech in terms of its contribution to political discourse. ${ }^{110}$ According to Meiklejohn, "[w]hat is essential is not that everyone shall speak, but that everything worth saying shall be said." ${ }^{, 11}$ Under this justification, however, only speech that contributes to self-governance is protected. As Owen Fiss observes, "[s]peech is valued so importantly in the Constitution ... not because it is a form of self-expression or selfactualization but rather because it is essential for collective selfdetermination." $" 12$

However, speech of private concern often does not promote democratic self-governance. For example, it is difficult to justify how the sale from one company to another of mailing lists about people's hobbies and incomes promotes democratic self-governance. Additionally, the reporting of one's personal secrets often does not illuminate the sphere of politics. In fact, privacy protections against disclosure strongly promote democratic self-governance. As Keith Boone contends: "Privacy seems vital to a democratic society [because] it underwrites the freedom to vote, to hold political discussions, and to associate freely away from the glare of the public eye and without fear of reprisal." ${ }^{, 13}$ Thus, privacy can contribute to a robust public life rather than detracting from it.

Privacy encourages uninhibited speech by enabling individuals to direct frank communication to those people they trust and who will not cause them harm because of what they say. Important discourse, especially communication essential for democratic participation, often takes place in microlevel contexts (between two people or in small

110. See Alexander Meiklejohn, Political Freedom: The Constitutional POWERS OF THE PEOPLE 154-55 (1960) (noting that the First and Fifth Amendments "requir[e] of free citizens and of free institutions that they resist with all their might the irresponsible usurpations of a legislature which would attempt to tell men what they may believe and what they may not believe, with whom they may associate and with whom they may not associate").

111. Id. at 26 .

112. OWEn M. Fiss, The IRONY OF FreE SPEECH 3 (1996). As Owen Fiss further argues:

On the whole does [speech] enrich public debate? Speech is protected when (and only when) it does, and precisely because it does, not because it is an exercise of autonomy. In fact, autonomy adds nothing and[,] if need be ... might have to be sacrificed, to make certain that public debate is sufficiently rich to permit true collective self-determination.

Owen M. Fiss, Free Speech and Social Structure, 71 IOWA L. REV. 1405, 1411 (1986); see also OWEn M. Fiss, Liberalism Divided: FreEdom of SPEECH AND THE MANy Uses of StATE POWER 36-38 (1996) ("[A] utonomy is not protected as an end in itself . . . Rather, it is seen as a way of furthering the larger political purposes attributed to the First Amendment.").

113. C. Keith Boone, Privacy and Community, 9 SoC. THEORY \& PRAC. 1, 8 (1983). 
groups) rather than in macrolevel contexts (public rallies or nationwide television broadcasts). Indeed, a significant amount of political discussion occurs not on soapboxes or street corners, but within private conversations. Protections against disclosure enable us to communicate with others without risking more widespread disclosure. Communication often occurs within the context of a relationship, in which people already share mutual knowledge, and their communication is frequently part of a continuing dialogue. For this reason, communication is especially prone to misinterpretation when disclosed to people lacking the same background information. Further, much communication occurs only because of the trust that has developed between communicants; without privacy, people might not communicate many ideas. People might be more reluctant to criticize aspects of their public lives, such as their employers, if they could not do so in private. ${ }^{114}$ The threat of disclosure probably will not end all conversations, but it will alter what is said. Therefore, privacy protections do not just inhibit free speech; they can promote it as well.

One criticism of the view that privacy helps promote free speech is that the Constitution protects speech, not privacy. Volokh argues:

$[\mathrm{T}]$ he speech vs. privacy and speech vs. speech tensions are not tensions between constitutional rights on both sides. The Constitution presumptively prohibits government restrictions on speech and perhaps some government revelation of personal information, but it says nothing about interference with speech or revelation of personal information by nongovernmental speakers. ${ }^{115}$

Although Volokh reads the First Amendment narrowly to focus primarily on speech, freedom of speech and the press are only one dimension of the First Amendment. It also explicitly protects the right to assemble, the right to petition one's government, and the right to free exercise of religion. ${ }^{116}$ The First Amendment is thus about much more than speech. Indeed, the First Amendment has been interpreted rather expansively-beyond merely protecting speech-to promote democratic self-governance. For example, in one series of cases the

114. WeStin, supra note 104 , at 35.

115. Volokh, supra note 32, at 1107.

116. The full text of the First Amendment provides: "Congress shall make no law respecting an establishment of religion, or prohibiting the free exercise thereof; or abridging the freedom of speech, or of the press; or the right of the people peaceably to assemble, and to petition the government for a redress of grievances." U.S. CONST. amend. I. 
Court held that the First Amendment creates a right to access certain judicial proceedings because a "major purpose" of the Amendment is "to protect the free discussion of governmental affairs." "117

First Amendment jurisprudence recognizes the importance of privacy in promoting First Amendment interests. The First Amendment protects freedom of association, ${ }^{118}$ which is integral to the formation of political views and the execution of political action. ${ }^{119}$ Protection against disclosure protects freedom of association, for it enables people to join together and exchange information without having to fear loss of employment, community shunning, and other social reprisals. ${ }^{120}$ Freedom of association guards against the "tyranny of the majority," 2121 for it allows those with minority viewpoints to form into groups to achieve greater social power. Privacy enables minorities and outsider groups freedom for self-development and group interaction without undue impingement by the norms of the majority.

Furthermore, the Court recognizes that the privacy involved in anonymous communication can be essential for the promotion of free speech. In Talley v. California, ${ }^{122}$ the Court struck down an ordinance

117. Globe Newspaper Co. v. Super. Ct., 457 U.S. 596, 604 (1982). See also Press-Enterprise Co. v. Super. Ct., 478 U.S. 1, 10 (1986) (holding that the First Amendment mandates access to preliminary hearings); Press-Enterprise Co. v. Super. Ct., 464 U.S. 501, 509 \& n.8, 513 (1984) (recognizing that the First Amendment mandates public access to voir dire). For more background on the First Amendment right to access court proceedings, see Daniel J. Solove, Access and Aggregation: Public Records, Privacy and the Constitution, 86 MINN. L. REV. 1137, 1201-06 (2002).

118. "Congress shall make no law ... abridging ... the right of the people peaceably to assemble." U.S. CONST. amend. I.

119. 1 Alexis De TocQueville, Democracy In America 196 (Phillips Bradley trans., Vintage Books 1990) (1840):

The most natural privilege of man, next to the right of acting for himself, is that of combining his exertions with those of his fellow creatures and of acting in common with them. The right of association therefore appears to me almost as inalienable in its nature as the right of personal liberty.

120. See EdWARd J. BlousteIn, IndividuAL AND GROUP PRIVACY 125 (1978) (arguing that group privacy "requires that people reveal themselves to one another-breach their individual privacy - and rely on those with whom they associate to keep within the group what was revealed"); see also Bates v. City of Little Rock, 361 U.S. 516, 524 (1960) (noting that the disclosure of NAACP's members and contributors is unconstitutional because disclosure would lead to "community hostility and economic reprisals"); NAACP v. Alabama, 357 U.S. 449, 46263 (1958) ("[C]ompelled disclosure ... may induce members to withdraw from the Association and dissuade others from joining it because of fear of exposure of their beliefs shown through their associations and of the consequences of this exposure.").

121. TOCQUEVILLE, supra note 119 , at 194.

122. 362 U.S. 60 (1960). 
prohibiting the distribution of anonymous pamphlets. The Court noted the profound importance of anonymous speech, especially to enable "[p]ersecuted groups and sects" to "criticize oppressive practices." reprisal might deter perfectly peaceful discussions of public matters of importance." ${ }^{124}$ Similarly, in Watchtower Bible \& Tract Society v. Village Of Stratton, ${ }^{125}$ the Court struck down an ordinance requiring door-to-door solicitors to identify themselves and their organizations because it "may preclude such persons from canvassing for unpopular causes." ${ }^{126}$ The anonymity cases broadly demonstrate the important connection between privacy and speech. Without privacy, certain core political speech would not occur.

It is certainly true that the freedom of association and anonymity cases involve government disclosures rather than disclosures by nongovernmental parties. Nevertheless, these cases illustrate the link between privacy and the interests promoted by the First Amendment. In Bartnicki v. Vopper, ${ }^{127}$ the Supreme Court partially struck down a provision in the Electronic Communications Privacy Act that made people liable for disclosing information that they knew was obtained by an illegal wiretap. ${ }^{128}$ The Court limited its holding to information of public concern. ${ }^{129}$ In a concurring opinion, Justice Breyer stated that the Court's constitutional analysis should focus on "whether the statutes strike a reasonable balance between their speech-restricting and speech-enhancing consequences." ${ }^{, 130} \mathrm{He}$ noted that the "statutory restrictions before us directly enhance private speech" because "[m]edia dissemination of an intimate conversation to an entire community will often cause the speakers serious harm over and above the harm caused by an initial disclosure to the person who intercepted the phone call." ${ }^{131}$ According to Rodney Smolla, "Bartnicki accepted

123. Id. at 64 .

124. Id. at 65. See also Buckley v. Amer. Constitutional Law Found., 525 U.S. 182, 200 (1999) (striking down statute requiring individuals handing out petitions to wear nametags); McIntyre v. Ohio Elections Comm'n, 514 U.S. 334, 341-43 (1995) (holding that a ban on the anonymous distribution of campaign literature violates the First Amendment).

125. 122 S. Ct. 2080 (2002).

126. Id. at 2090 .

127. 532 U.S. 514 (2001).

128. See id. at 535 (concluding that the First Amendment protects disclosure of illegally obtained information of public concern by an unknown person).

129. Id. at 533-34.

130. Id. at 536 (Breyer, J., concurring).

131. Id. at 537 (Breyer, J., concurring). 
the premise that the conflict posed between speech and privacy is a conflict between two rights of constitutional stature. By this important measure, all nine Justices in Bartnicki were in agreement." ${ }^{132}$

Volokh's argument rests on the view that the Constitution protects only negative liberty-freedom from government interference. Negative liberty is the central focus in John Stuart Mill's On Liberty, ${ }^{133}$ and Mill described freedom of speech in negative terms, pointing out when the government should refrain from regulating speech. Under Volokh's negative liberty view of the First Amendment, restrictions on speech that result in a net increase in the promotion of First Amendment interests are still unconstitutional.

But there is another form of liberty-positive liberty-which involves instances in which the state should protect liberty by means of affirmative regulation. ${ }^{134}$ According to John Dewey, liberty is an evolving concept, and the state must often act affirmatively to ensure liberty. ${ }^{135}$ Cass Sunstein and others argue that the Constitution should (and does) mandate the protection of positive liberty. ${ }^{136}$ But even if the Constitution does not provide for positive liberty, it need not be hostile to legislative attempts to achieve positive liberty. Privacy regulations that promote speech should not simply be viewed in terms of their speech-restrictive elements; they should be understood holistically, in terms of their overall purpose in the protection of free speech. We protect free speech to promote certain ends. Volokh loses sight of the ends of the First Amendment by focusing too heavily on the means.

132. Rodney A. Smolla, Information as Contraband: The First Amendment and Liability for Trafficking in Speech, 96 Nw. U. L. REV. 1099, 1150 (2002).

133. See John StUART Mill, ON LiberTy 10 (David Spitz ed., 1975) ("[T]he sole end for which mankind are warranted, individually or collectively, in interfering with the liberty of action of any of their number, is self-protection.").

134. ISAIAH BERLIN, FOUR ESSAYS ON LIBERTY xxxvii-lxiii (1969); Isaiah Berlin, Two Concepts of Liberty, in FOUR ESSAYS ON LIBERTY, supra, at 118, 118-72. Cass Sunstein terms the positive liberty approach to free speech the "New Deal" approach. Cass R. Sunstein, Free Speech Now, 59 U. CHI. L. REV. 255, 263-300 (1992).

135. JOHN DEWEY, LIBERALISM AND SOCIAL ACTION (1935), reprinted in 11 JOHN DEWEY: THE LATER WORKS, 1925-1953, at 1, 18 (Jo Ann Boydston ed., 1987).

136. In a related manner, Cass Sunstein argues that "legal rules designed to promote freedom of speech should not be invalidated if their purposes and effects are constitutionally valid, even if they conspicuously intrude on the rights of some property owners and even some speakers." SUNSTEIN, supra note 65 , at 37 . Sunstein argues that "constitutional validity should be assessed in Madisonian terms: Do the rules promote greater attention to public issues? Do they ensure greater diversity of view?" Id. 
3. The Marketplace of Ideas. A third well-known justification for free speech is that it contributes to the promotion of truth. This justification was most famously propounded by John Stuart Mill, who observed that government censorship of speech destroys "the opportunity of exchanging error for truth."137 "All silencing of discussion is an assumption of infallibility," argued Mill, and those "who desire to suppress [free speech] are not infallible."138 As Isaiah Berlin notes, Mill's argument assumes that knowledge is "in principle never complete, and always fallible" and that there is "no single, universally visible, truth." ${ }^{139}$

Justice Holmes drew from this theory when he articulated the notion of the marketplace of ideas:

[W]hen men have realized that time has upset many fighting faiths, they may come to believe even more than they believe the very foundations of their own conduct that the ultimate good desired is better reached by free trade in ideas-that the best test of truth is the power of the thought to get itself accepted in the competition of the market, and that truth is the only ground upon which their wishes safely can be carried out. ${ }^{140}$

The marketplace of ideas locates the value of free speech in finding the truth, and it makes the market the arbiter of truth or falsity. Hence, the law must avoid becoming involved in discerning true and false information-only the market should decide. Under this rationale, the First Amendment should prohibit privacy protections on disclosure because they hinder the quest for the truth.

However, the marketplace theory assumes that the value of truth is nearly absolute, an assumption that is not always correct. Frederick Schauer contends that commentators have too readily assumed that "truth is an ultimate, irreducible, and noninstrumental value." ${ }^{141}$ Instead, truth is a value that must be weighed against other values.

137. MILL, supra note 133, at 18.

138. Id.

139. Berlin, Two Concepts of Liberty, supra note 134, at 188.

140. Abrams v. United States, 250 U.S. 616, 630 (1919) (Holmes, J., dissenting).

141. Frederick Schauer, Reflections on the Value of Truth, 41 CASE W. RES. L. REV. 699, 706 (1991); see also Anita L. Allen, The Power of Private Facts, 41 CASE W. RES. L. REV. 757, 766 (1991) (arguing that allocations of power can sometimes be more valuable than the protection of true speech); Julie E. Cohen, Privacy, Ideology, and Technology: A Response to Jeffrey Rosen, 89 GEO. L.J. 2029, 2036 (2001) ("The belief that more personal information always reveals more truth is ideology, not fact, and must be recognized as such for informational 
As I argue throughout this Article, the law of evidence has much to teach us. The law of evidence has long recognized privacy as an important goal that can override the truth-seeking function of the trial; valuable evidence is excluded from trials based on evidentiary privileges. As one nineteenth-century English judge observed:

Truth, like all other good things, may be loved unwisely-may be pursued too keenly_may cost too much. And surely ... the general evil of infusing reserve and dissimulation, uneasiness, and suspicion and fear, into those communications which must take place, and which, unless in a condition of perfect security, must take place uselessly or worse, [is] too great a price to pay for truth itself. ${ }^{142}$

There are many "truths" that are not worth much effort to find out. For example, there is a true answer to the number of paperclips I have in my office, but this information does not have much value. Much true information is trivial and useless. The value of the quest for the truth depends upon what information one is seeking. What is the value of the truth about a private figure's personal life? The marketplace theory does not provide an answer. In fact, the marketplace theory is really an argument for neutrality: because everyone is fallible, it is best to leave free speech unencumbered. Neutrality may be desirable when it comes to ideas and opinions about public matters, and this is the focus of Mill's powerful argument against government censorship in On Liberty. Speech about private matters, however, is different. In many instances, as I argue in Part II, privacy outweighs the value of true speech. Also, as Part II discusses, if one is committed to the quest for truth, the disclosure of true private information can actually inhibit this pursuit. ${ }^{143}$

Therefore, restrictions on speech of private concern should receive less stringent scrutiny than do restrictions on speech of public concern. If we value free speech instrumentally, then the law should maximize the interests justifying free speech. A balance between privacy and speech achieves these interests better than protecting speech alone. Even if speech is valuable for its own sake, privacy can

privacy to have a chance."). For a critique of Schauer's position, see Erwin Chemerinsky, In Defense of Truth, 41 CASE W. RES. L. REV. 745 (1991).

142. Pearse v. Pearse, 63 Eng. Rep. 950, 957 (Ch. 1846) (Bruce, V.C.).

143. One might counter that when the government declares that certain truths are of less value than others, the government is interfering in the debate. To assess the value of a truthseeking activity, one must engage in it. Therefore, restricting a truth-seeking activity inhibits our ability to ascribe the appropriate value to it. In response to this argument, we already have ample experience with speech of private concern to assess its value appropriately. 
enhance freedom of speech more than a rigid protection of all forms of speech. Because the disclosure of private information can inhibit free speech, we cannot assume that all restrictions on speech will cause a net loss to freedom of speech. In fact, some restrictions on speech can enhance our freedom to speak.

Underpinning the discussion thus far is the distinction between public and private concerns. I have argued that personal information of public concern has a much higher value than personal information relating to a private concern. The next Section explores how the law should distinguish between speech of public and private concern.

\section{Distinguishing Public from Private Concerns}

How should the law distinguish between speech of public and private concern? Dun \& Bradstreet did not elaborate upon the meaning of the public and private concern distinction when holding that credit reports were of private concern. ${ }^{144}$ Likewise, the Court's privacy law cases-Smith v. Daily Mail Publishing Co.,${ }^{145}$ Florida Star v. B.J.F., ${ }^{146}$ and Bartnicki v. Vopper $^{147}$ - did little to define the distinction.

The distinction between public and private concerns is more fully developed in the tort of public disclosure. In this context, the prevailing approach for balancing First Amendment interests with privacy is the newsworthiness test, which prohibits liability when information is of "legitimate concern to the public." 148 The newsworthiness test is an element of the tort, a built-in protection for the free speech. Information is of public concern when "the public has a proper interest in learning about [it]." ${ }^{149}$ For example, the Restatement of Torts distinguishes between "information to which the public is entitled" and "morbid and sensational prying into private lives for its own sake, with which a reasonable member of the public, with decent standards, would say that he had no concern." ${ }^{150}$

144. Rodney A. Smolla, Dun \& Bradstreet, Hepps, and Liberty Lobby: A New Analytic Primer on the Future Course of Defamation, 75 GEO. L.J. 1519, 1540 (1987).

145. 443 U.S. 97 (1979).

146. 491 U.S. 524 (1989).

147. 532 U.S. 514 (2001).

148. RESTATEMENT (SECOND), supra note 11, § 652D.

149. Id. $\S 652 \mathrm{D} \mathrm{cmt.} \mathrm{d.}$

150. Id. $\S 652 \mathrm{D} \mathrm{cmt}$. h. 
The newsworthiness test emerges from Warren and Brandeis's article, The Right to Privacy. ${ }^{151}$ According to Warren and Brandeis, " $[\mathrm{t}]$ he right to privacy does not prohibit any publication of matter which is of public or general interest." ${ }^{, 152}$ Smolla reads Bartnicki to be "inviting the importation into First Amendment jurisprudence of the 'newsworthiness' analysis as it has developed so far in common-law cases." ${ }^{153}$ Therefore, it is appropriate to turn to the public disclosure tort cases for guidance on how courts have distinguished between matters of public and private concern.

Courts have long struggled when applying the newsworthiness test, and they have adopted a number of different approaches. ${ }^{154}$ Among the approaches to distinguishing public from private concerns, three predominate: (1) deferring to the media; (2) focusing on the status of the individual, e.g., whether she is a public or private figure; and (3) examining the nature of the information, e.g., whether it relates to public affairs or matters typically considered private, such as sex and health. Some approaches involve a combination of (2) and (3). I contend that all of these approaches are deeply flawed.

Nevertheless, I do not recommend that the attempt to distinguish between speech of public and private concern be abandoned. Courts have entrenched the distinction in the doctrine, and the Supreme Court has begun to incorporate it into its jurisprudence. Because I advocate developing the existing doctrine rather than writing on a clean slate, I propose a new approach to making the distinction, rather than a more radical change in the distinction itself.

\section{Prevailing Approaches.}

a. Deference to the Media. A number of courts defer to the editorial judgment of the media to distinguish between public and private concerns. ${ }^{155}$ As one court noted: "[W]hat is newsworthy is

151. Warren \& Brandeis, supra note 8 , at 214-16.

152. Id. at 214 .

153. Smolla, supra note 132, at 1153.

154. See Geoff Dendy, Note, The Newsworthiness Defense to the Public Disclosure Tort, 85 KY. L.J. 147, 157-64 (1997) (describing five different approaches that courts have used to analyze the newsworthiness defense).

155. Wagner v. Fawcett Publ'ns, 307 F.2d 409, 410-11 (7th Cir. 1962); Jenkins v. Dell Publ'g. Co., 251 F.2d 447, 451-52 (3d Cir. 1958); Berg v. Minneapolis Star \& Tribune Co., 79 F. Supp. 957, 960-61 (D. Minn. 1948). 
primarily a function of the publisher, not the courts." Harry Kalven agrees that the media "must in the nature of things be the final arbiter of newsworthiness." 157 This is called the "leave-it-tothe-press" approach. ${ }^{158}$

The leave-it-to-the-press approach turns on a distrust of the legislature (statutory disclosure restrictions) and of judges and juries (privacy torts). Can these decisionmakers be entrusted to determine what is newsworthy? Volokh argues that it is extremely problematic when the government decides what subjects people can talk about. Specifically, Volokh observes:

Under the First Amendment, it's generally not the government's job to decide what subjects speakers and listeners should concern themselves with. A private concern exception essentially says "you have no right to speak about topics that courts think are not of legitimate concern to you and your listeners," a view that's inconsistent with this understanding. ${ }^{159}$

If courts, legislatures, or juries defer to the press, then the newsworthiness standard is practically eviscerated. On the other hand, if they do not defer, then they are establishing limits to editorial judgment, which critics argue is paternalistic.

The result is a complicated legal process determination about who is the best decisionmaker: legislatures, judges or juries, or journalists. As Diane Zimmerman argues, the press "has a better mechanism for testing newsworthiness than do the courts. ... Unlike judges and jurors, the press must develop a responsiveness to what substantial segments of the population want (and perhaps even need) to know to cope with the society in which they live." 160 Proponents of

156. Heath v. Playboy Enters., Inc., 732 F. Supp. 1145, 1149 (S.D. Fla. 1990).

157. Kalven, supra note 28, at 336.

158. Zimmerman, supra note 29, at 353; see also Leon Green, Continuing the Privacy Discussion: A Response to Judge Wright and President Bloustein, 46 TEX. L. REV. 750, 753 (1968) (noting that "the sense of decency of the important publication media" would restrict reported cases to those in which "the dignitary harms inflicted would probably be considered overbalanced by the newsworthiness of the items published"). Rodney Smolla suggests that the "leave-it-to-the-press" approach is buttressed by "legal and cultural forces." Rodney A. Smolla, Accounting for the Slow Growth of American Privacy Law, 27 NovA L. REV. 289, 304 (2002). Smolla notes that there is an "ingrained skepticism" for restricting the publication of true information and a "reflexive wariness" of permitting the government to "second-guess" the judgment of speakers about what is "worthy of being said." Id.

159. Volokh, supra note 32, at 1089 (citation omitted).

160. Zimmerman, supra note 29, at 353-54; see also Kalven, supra note 28, at 336 ("[T] press must in the nature of things be the final arbiter of newsworthiness."). 
deference to the media conclude that journalists are the best decisionmakers because they are most responsive to what the public will find interesting. Under this view, the media will be responsive to market pressures, and the market reflects what the public wants to know. ${ }^{161}$ Although the media may make the initial decision to report a story, if the public lacks interest, ratings will eventually plummet. The market thus provides feedback to the media about the kinds of stories that the public desires.

Even if the media is the most accurate decisionmaker for gauging public interest, it might not be the best decisionmaker for determining what is newsworthy. What is of interest to most of society is not the same question as what is of legitimate public concern. It is possible that people will want to hear a story even when they do not consider it of legitimate public concern. For example, a video of Pamela Anderson Lee having sex with Bret Michaels was sold over the Internet, generating hundreds of thousands of dollars in revenue. ${ }^{162} \mathrm{~A}$ video of the president giving a speech would be much less lucrative. Does this make the sex tape more newsworthy? The market measures the public's interest in a particular matter, but this interest can stem from a desire for entertainment or sexual pleasure just as much as it can from wanting to learn about the news and current events. ${ }^{163}$

Although it is often assumed that the market represents an accurate reflection of the public's preferences in the aggregate, this assumption is false not only because the media actively shapes the market, but also because market pressures are not always in sync with public demand. ${ }^{164}$ Journalists are not simply responsive to market forces; they also influence the market by defining and enlarging the public sphere. By reporting a particular story, the media can generate attention for that story that might not otherwise exist, because many people consume news based on brand name rather than content. In

161. Edwin Baker has extensively critiqued the view that the market is the appropriate mechanism to measure what media products the public wants to consume. C. EDWIN BAKER, MEDIA, MARKETS, AND DEMOCRACY 63-95 (2002). Baker argues that the market weighs the preferences of the wealthy more heavily than those of the poor because the wealthy are willing to pay more to satisfy their preferences. Id. at 72. However, "[n]othing about being wealthy implies that a person's preferences are stronger." $I d$.

162. See Michaels v. Internet Entm't Group, Inc., 5 F. Supp. 2d 823, 837 (C.D. Cal. 1998) (acknowledging the president of Internet Entertainment Group's estimate that the company would lose one third of its $\$ 1,495,000$ subscription revenue without the Bret Michaels and Pamela Anderson sex video).

163. I thank Lior Strahilevitz for suggesting this example to me.

164. See supra note 161. 
other words, people read their daily papers and watch their favorite television news programs; often they do not select whether to read or watch each particular story. The media is also a powerful shaper of privacy norms in society. As more stories report on private matters, our expectations of privacy change. Therefore, the media does not simply react to public demand; it manufactures demand by reconstructing the public sphere to include more private matters. The mass media, Jürgen Habermas argues, has become transformed into "primarily a business." ${ }^{165}$ It no longer amplifies public debate, but actively shapes it. ${ }^{166}$

Moreover, widely reported stories are difficult for people to ignore. People generally discuss what is in the news, but not necessarily because it is of the most interest to them. Often, people discuss whatever news the media provides. The press creates interest in particular events. We want to find out whether the baby who falls into a well is rescued because we are now in the middle of a story.

The media often bases decisions about what stories to run upon assumptions that its audience is relatively unintelligent, has a very short attention span, and is unable to deal with nuance, ambiguity, and complexity. According to a Pew poll, 77 percent of journalists avoid stories that they think are "important but dull," and 52 percent avoid "overly complex stories." ${ }^{167}$ Even if the media's perceptions of the public are true, the way that people are treated can become a selffulfilling prophecy. Educational studies, for example, show that students perform significantly better when teachers expect them to perform at a high ability level ${ }^{168}$ The media does more than merely report; it educates and indoctrinates. It therefore is not merely responsive to the public, but it shapes the public as well.

Proponents of deference can respond by pointing out that the media can and does exercise self-restraint in many cases. For

165. Jürgen Habermas, The Structural Transformation of the Public SPhere 184 (Thomas Burger trans., MIT Press 1989) (1962).

166. Id. at 188 .

167. Pew Research Center for the People \& the Press, Self Censorship: How Often and Why (Apr. 30, 2000), at http://people-press.org/reports/display.php3?ReportID=39 (on file with the Duke Law Journal).

168. See Janet Weinstein, And Never the Twain Shall Meet: The Best Interests of Children and the Adversary System, 52 U. MiAMI L. REV. 79, 142 n.210 (1997) (noting that "students perform in accordance with their teachers' expectations of their abilities"); Angelia Dickens, Note, Revisiting Brown v. Board of Education: How Tracking Has Resegregated America's Public Schools, 29 ColuM. J.L. \& Soc. Probs. 469, 477-78 (1996) (discussing how teachers' "lower expectations become a self-fulfilling prophecy"). 
example, during the presidency of John F. Kennedy, the media avoided reporting on his sexual infidelities. ${ }^{169}$ Today, this norm has changed, as was emphatically demonstrated by the extensive reporting on President Clinton's affairs. Although the media readily plunders the private lives of politicians, it continues to exercise great restraint with their children. President Clinton actively worked to keep his daughter, Chelsea, away from the media ${ }^{170}$ the media avoided coverage of Chelsea. ${ }^{171}$ When Chelsea attended Stanford University, the editors of the Stanford Daily even resolved to fire any member of its staff who disclosed information about Chelsea to the public. ${ }^{172}$ The press has also exercised restraint for President Bush's daughters, and when one daughter was arrested for underage drinking, the media was deeply divided about the extent of coverage to give to the story. ${ }^{173}$ These norms exist in spite of great public interest in the children's lives and despite the fact that some voters may find information about a politician's children to be relevant to their overall assessment of the politician.

Another longstanding media norm is refraining from identifying rape victims. For example, in August 2002, two teenage girls were kidnapped and raped. While they were captive, their names and photographs were widely broadcast to assist in the search. Once they were found alive, most of the media ceased displaying their names

169. See Rodney A. Smolla, Free Speech in An Open Society 134 (1992) ("When the press avoided reporting on the sexual liaisons of John Kennedy, however, it engaged in a paternalistic decision that the behavior was not probative of Kennedy's fitness for public life."); Jeffrey B. Abramson, Four Criticisms of Press Ethics, in DEMOCRACY AND THE MASS MEDIA 229, 234 (Judith Lichtenberg ed., 1990) ("There was also the nonreporting of the love lives of Lloyd George, Franklin Roosevelt, Dwight Eisenhower, John Kennedy, and Martin Luther King, Jr.").

170. See Ellen O'Brien, Chelsea Comes of Age, but Not Before Our Eyes, Boston GloBE, Sept. 4, 1994, at 1 ("That Chelsea has led a life outside the public eye is no accident; the Clintons have worked hard at it.").

171. Joan Ryan, Clintons Let Go-Chelsea Enters Stanford, S.F. CHRON., Sept. 20, 1997, at A1; see Howard Kurtz, First Daughter's Privacy No Longer Off Limits, CHI. Sun-TIMES, Nov. 27, 1998, at 32 ("For six years the media followed an unspoken pact to avoid coverage of Chelsea Clinton, allowing the president's daughter to grow up outside the harsh glare of publicity.").

172. Ryan, supra note 171.

173. See, e.g., Gail Collins, The Children's Crusade, N.Y. TIMES, May 1, 2001, at A23 (arguing that "it's always news when the offspring of important elected officials break the law," but noting that when "there's no legal issue involved, it's a judgment call"); Joanne Ostrow, Don't Beat About the Bush Kids, DenVER Post, June 10, 2001, at K1 (questioning whether "the media [went] overboard in reporting Jenna Bush's recent underage drinking citation”). 
and photographs. ${ }^{174}$ Although this norm is widely followed, ${ }^{175}$ there are occasional violators, a recent example being the radio commentator who disclosed the identity of Kobe Bryant's alleged sexual assault victim. ${ }^{176}$

The media's norms do not always align with society's norms. Perhaps this disparity accounts for the public's general distrust of the media. In a December 2001 Harris Poll, for example, journalists ranked close to the bottom of seventeen professions, earning the trust of only 49 percent of poll respondents. ${ }^{177}$ The same disparities also apply to norms about privacy. In a poll by the Center for Media and Public Affairs, 80 percent of the public responded that the media "often invade[] people's privacy.",178

Media self-restraint is difficult to achieve because the media is far from a monolithic entity. There are many different styles of journalism, and a vast number of media entities cater to different tastes. If the New York Times will not report it, the National Enquirer will. As a result, certain segments of the media-such as tabloidsmay routinely run stories that a majority of the media does not consider newsworthy. Such differences reflect the different norms within the various segments of the media.

Furthermore, a collective action problem exaggerates the differences between societal and media norms. As Jack Balkin argues, "journalists as a whole face a collective action problem in maintaining the boundaries of what is public and what is private. If one journalist changes the contours of the public through a series of revelations, other journalists may feel compelled to follow along." ${ }^{179}$ In other words, if a segment of the media breaks a story that other segments do not find newsworthy, the other segments may change their view because "[j] ournalists may feel duty bound to report whatever is in

174. David Bauder, Identifying Rape Victims Troubles Media, Sun-SENTINEL (Ft. Lauderdale), Aug. 3, 2002, at 3A; Richard Roeper, Case Shows Absurdity of Media's Rape ID Policy, ChI. Sun-Times, Aug. 5, 2002, at 11.

175. See Roeper, supra note 174 ("So the media were tripping all over themselves trying to stick to policy—but hardly anyone questioned whether the policy itself is outdated.").

176. Chris Frates, L.A. Radio Show Names Bryant's Accuser, DenVer Post, July 24, 2003, at B1.

177. Humphrey Taylor, Whom Do We Trust to Tell the Truth? Whom Do We Trust the Least?, THE HARRIS POLL (Dec. 12, 2001), at http://www.harrisinteractive.com/harris_poll/ printerfriend/index.asp?PID=273 (on file with the Duke Law Journal).

178. John Carmody, The TV Column, WASH. Post, Sept. 15, 1997, at B6.

179. J.M. Balkin, How Mass Media Simulate Political Transparency, 3 Cultural Values 393, 402 (1999). 
fact in the public sphere of discussion." ${ }^{180}$ The argument for not regulating the norms of smaller segments of the media is often made in the service of promoting pluralism-allowing different types of stories for different tastes. Those interested in prurience and peccadilloes can tune into tabloid television; those interested in politics and policies can turn to a respectable news channel. In the end, however, there may be less pluralism, not more. Because the rest of the media may be pressured into following along, the result tends toward uniformity. The respectable news channel, for example, may gradually gravitate toward reporting on issues that it ordinarily would never have covered or would have covered only in very little depth.

Allowing media norms to develop on their own could shift coverage toward the sensationalistic, which might be optimal for media profit margins but not for society as a whole. Under numerous theories of democracy, information is essential for public discourse. However, journalists do not necessarily increase the total information available to the public by reporting on private matters. Rather, as Balkin argues, "journalists may in fact simply be altering the mix of stories presented to the public; the practical effect [being] a contraction of the scope of public discourse." ${ }^{, 181}$ Balkin's argument is similar to what Warren and Brandeis argued in 1890: "When personal gossip attains the dignity of print, and crowds the space available for matters of real interest to the community, what wonder that the ignorant and thoughtless mistake its relative importance." 182 Left unchecked, the media alters the nature of public discourse. Therefore, public discourse should not be defined exclusively by the norms of one social sector (the media), especially when those norms often do not mirror those of the rest of society.

Although the media may have deficiencies as a decisionmaker, are courts, juries, or legislatures better? Certainly, one cannot say that systematically, courts/juries and legislatures are better than the media at determining what is of public or private concern. Each type of entity has special abilities and faults. Legislatures, courts, and juries are sometimes representative of the populace. On the other hand, legislatures can also be captured by special interests, and juries can be overly influenced by a sympathetic plaintiff or an eloquent attorney. There is no single optimal decisionmaker, but the combination of all

180. Id.

181. Id.

182. Warren \& Brandeis, supra note 8, at 196. 
of these decisionmakers is preferable to the dominance of only one. Thus, the public disclosure tort is a way for society to inform the media that it disapproves of the balance that the media has struck with privacy. I use the word "society" rather than "government" because there are many times in which legislatures, judges, and juries can speak for society. The problem, of course, is that no one institution can completely and precisely represent society.

Like most social institutions, the media is flawed. It is also tremendously powerful, and given this reality, it might not be wise to accord it deference. Thus, the media should not have a monopoly on determining what is of public concern. Ultimately, such an important decision is for all of society to make, not just one segment of society or one type of social institution.

b. The Status of the Individual. In another approach to distinguishing between public and private concerns, courts frequently look to the status of the individual whose information is disclosed. This approach looks to whether the person is a public or private figure, with the general rule that disclosures of information about public figures are of public concern. For example, Rodney Smolla argues that public figures should not be permitted to sue for public disclosure, even if the information is not newsworthy: "[W]hen public figures are involved, it is impossible to reach a judgment that a fact is or is not newsworthy without engaging in value judgments that draw from ideological and cultural biases." ${ }^{183}$ Thus, Smolla contends that the law should protect private figures but not public ones.

The distinction between public and private figures hails from defamation law. Public figures include not only politicians and public officials, but famous people, celebrities, and people involved in public controversies. Originally, in New York Times Co. v. Sullivan, ${ }^{184}$ the Court provided strict limits on defamation recovery for public officials. ${ }^{185}$ Later, however, the Court extended these limits to all public figures. ${ }^{186}$ The result is that all public figures, whether they are

183. SMOLLA, supra note 169 , at 125.

184. 376 U.S. 254 (1964).

185. See id. at 283 (requiring "proof of actual malice" before a public official may recover damages in a libel action).

186. See Curtis Publ'g Co. v. Butts, 388 U.S. 130, 155 (1967) (holding that "a 'public figure' who is not a public official" may only recover damages for defamation "on a showing of highly unreasonable conduct constituting an extreme departure" from responsible publishing standards). 
public officials or not, are treated the same. In Gertz v. Robert Welch, Inc. ${ }^{187}$ the Court held that there are two general types of public figures: (1) all-purpose public figures (people who have "general fame or notoriety"); and (2) limited public figures (people who are involved in a particular controversy) ${ }^{188}$ For limited public figures, "an individual voluntarily injects himself or is drawn into a particular public controversy and thereby becomes a public figure for a limited range of issues." 189 Under this approach, the scope of who can become a public figure is rather broad.

However, there are important reasons why focusing on public versus private figures does not adequately capture what is of public versus private concern. First, information about public figures is not always more important to society than information about private figures. Indeed, information about private figures can be more relevant to people's daily lives and decisions than data about public figures. For example, many people find it more important to know that the person babysitting their children has two prior child molestation convictions than the fact that a celebrity has a foot fetish.

Second, public figures are different from public officials, yet defamation law makes no distinction. In the context of defamation law, Frederick Schauer observes that if the purpose of First Amendment is "protection against a certain danger-a particularly likely form of governmental overreaching," sense to treat public officials like public figures. Public figures often do not "have some special access to or influence on the legislative process that is likely to cause their interests to be overprotected."191 Similarly, those who view the First Amendment as concerned with protecting speech about political matters, such as Cass Sunstein, agree that speech about "celebrities often does not involve politics." 192 Sunstein concludes that there is no need for the law to "provide special 'breathing space' to falsehoods about famous people."

Schauer and Sunstein's arguments, made in the context of defamation law, apply to privacy law as well. Celebrities and other

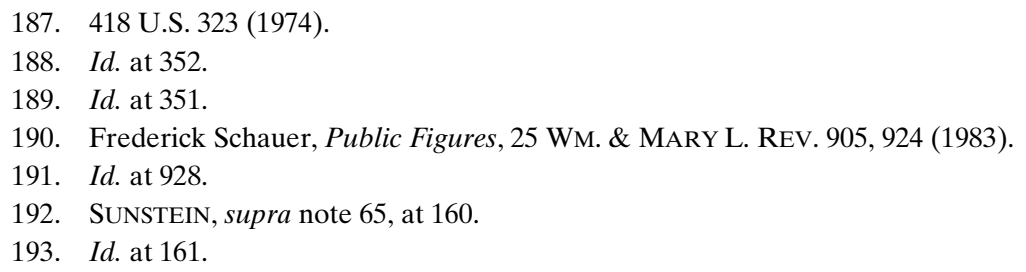


public figures should not be treated the same as public officials, because the interests behind the disclosure of information about public figures and public officials are different. Public officials are our representatives and spokespeople. Information about their finances and health are generally viewed as being of public concern. A candidate's socioeconomic background can shed light on that candidate's beliefs, values, and biases. Information about politicians' health can be relevant to how vigorously they can carry out their duties and whether they can live out a term in office. ${ }^{194}$ In contrast, similar information about a celebrity does not impact our political choices. Information about celebrities may be of interest or have entertainment value, but often it serves little other purpose.

Third, not all public officials are the same. Courts often lump public officials into the same category ${ }^{195}$ but there is a big difference between the nation's president and a local police officer or a teacher. The president's health, for example, is considered by many to be of public concern. This is hardly true for a bureaucrat, teacher, local prosecutor, or other minor public official.

Fourth, not all information about public officials-let alone public figures more generally-is of public concern. For example, it is hard to contend that the social security numbers of public officials are of public concern.

In the end, the status of the individual is a factor in helping to distinguish between what is of public or private concern, but it only goes so far.

c. The Nature of the Information. A third approach to distinguishing public from private concerns is to focus on the nature of the information, categorizing data contributing to democratic selfgovernance as being of public concern. Of course, the issue of what information assists democratic self-governance is a difficult question.

194. This is not to say that all information about public officials is of public concern. For an interesting argument that information about public officials' sex lives is sometimes not of public concern, see Anita L. Allen, Privacy and the Public Official: Talking About Sex as a Dilemma for Democracy, 67 GEO. WASH. L. REV. 1165 (1999).

195. See, e.g., Barry v. City of New York, 712 F.2d 1554, 1556, 1562 (2d Cir. 1983) (holding, in a constitutional right to information privacy suit, that the public's interest in knowing financial information about all civil service employees, including police and firemen, outweighed privacy interests); Plante v. Gonzalez, 575 F.2d 1119, 1136 (5th Cir. 1978) (holding that the public had a right to know financial information of a wide range of public officials in a constitutional right to information privacy suit). 
Drawing from Alexander Meiklejohn, many commentators make this determination by focusing on speech that aids political discussion and debate. For example, Edward Bloustein contends that newsworthy speech must be "relevant to the public's governing purpose," and he notes that there is no First Amendment right to "satisfy public curiosity and publish lurid gossip about private lives." ${ }^{, 196}$ Likewise, Paul Gewirtz contends: "The freedom of the press protected by the First Amendment must be seen as primarily about the press'[s] contribution to democratic self-governance, to public debate, and to checking the power of the state."

However, adopting a Meiklejohnian approach seems far too restrictive regarding what forms of speech may be of concern to the public. Such an approach would confine public matters to issues directly related to politics. But social practices and human behavior are often highly relevant to how people live their lives and understand society. The details of other people's private lives help illuminate these concerns. According to Volokh, speech about "daily life matters" is "at least equally worthy" as other forms of speech. ${ }^{198}$ Speech is not just limited to "ideological" messages. ${ }^{199}$ Although focusing exclusively on politics is too narrow, an approach that classifies all information of interest or entertainment value as public is too broad. If all such information were of public concern, it would be difficult to discern what could be private.

One solution is to draw lines based upon the intimacy of the information. Data about health and sex are private because these matters are deeply personal, whereas more innocuous information like names and addresses is not. Embodying this view, the Restatement notes that " $\mathrm{t}]$ here may be some intimate details of [an actress's] life, such as sexual relations, which even [she] is entitled to keep to herself." ${ }^{200}$

196. Edward J. Bloustein, The First Amendment and Privacy: The Supreme Court Justice and the Philosopher, 28 RUTGERS L. REV. 41, 56-57 (1974).

197. Paul Gewirtz, Privacy and Speech, 2001 Sup. Cт. ReV. 139, 172; see also Melville B. Nimmer, The Right to Speak from Times to Time: First Amendment Theory Applied to Libel and Misapplied to Privacy, 56 CAL. L. REV. 935, 962 (1968) ("[S]peech necessary for an effective and meaningful democratic dialogue by and large does not require references to the intimate activities of named individuals.").

198. Volokh, supra note 32, at 1092-93.

199. Id. at 1084.

200. RESTATEMENT (SECOND), supra note $11, \S 652 \mathrm{D} \mathrm{cmt}$. h. 
The problem with this approach is that often there are strong privacy interests in relatively innocuous information. For example, although an address is often not a private piece of information, for some people it can be quite important to keep their addresses confidential. Celebrities want to keep their addresses private to prevent being hounded and harassed by obsessed fans, stalkers, and paparazzi. Many other people may want their addresses kept secret, such as victims of stalkers or victims of domestic abuse who are seeking refuge from their abusers. Witnesses, jurors, or judges in a criminal case may need to conceal where they live to prevent retaliation against themselves and their families. In Kallstrom v. City of Columbus, ${ }^{201}$ police officers successfully prevented the disclosure of their home addresses because it could enable the criminals whom they arrested to seek them out and threaten their families. ${ }^{202}$ As this last example illustrates, the privacy of one's address can be an issue of safety and security. Another example is an incident in which a man purchased a woman's personal information from a database company, including her work address, then went to her workplace and killed her. ${ }^{203}$ Indeed, the Driver's Privacy Protection Act, ${ }^{204}$ which limits government disclosures of motor vehicle record information, was inspired by an incident in which a deranged fan murdered actress Rebecca Shaeffer outside her home after acquiring Shaeffer's address from the Department of Motor Vehicles. ${ }^{205}$

The "Nuremberg Files" case, Planned Parenthood v. American Coalition of Life Activists, ${ }^{206}$ involved a severe safety threat when an anti-abortion activist group published abortion doctors' names, photos, addresses, and descriptions of their cars on an Internet website. Names of doctors who were murdered were crossed out with a black line, and the names of wounded doctors were shaded in gray. The disclosure of this information, often relatively innocuous and not considered private, was quite an important matter for the doctors, who feared for their safety and that of their families. ${ }^{207}$ The doctors sued and won. Although address information is not sensitive or intimate, this does not automatically make it public. It is of public or

\footnotetext{
201. 136 F.3d 1055 (6th Cir. 1998).

202. Id. at 1069.

203. Remsburg v. Docusearch, Inc., 816 A.2d 1001, 1006 (N.H. 2003).

204. 18 U.S.C. $\S \S 2721-25$ (2000).

205. Solove, supra note 117 , at 1191.

206. 290 F.3d 1058 (9th Cir. 2002) (en banc).

207. Id. at 1065 .
} 
private concern depending upon the purposes for which people want to conceal it and the uses that others might make of it.

In sum, as an approach to distinguishing whether information is of public or private concern, focusing on the inherent nature of information is unadvisable, because the nature of information is context specific.

2. Looking to the Law of Evidence: A More Contextual Approach. If the above approaches cannot appropriately distinguish between public and private concerns, then how should the law draw this distinction? The law of evidence is instructive, not necessarily in its specifics, but in some of its basic ideas. Rules of evidence determine the admissibility of information based not only on the information's content, but also on the circumstances in which it is gathered, who is disclosing it, and what purpose its disclosure aims to achieve.

Thus far, the law has often viewed disclosure in black-and-white fashion. Information is classified as either of public or private concern, under the assumption that these are qualities that inhere in the information. ${ }^{208}$ The law must abandon this way of seeing the public and private distinction, and instead should focus on the appropriateness of the disclosure in context. ${ }^{209}$ Classifying a matter as of public concern means that it is appropriately disclosed to a particular audience in a particular situation. A disclosure that may be appropriate in one public context (an informal gathering among friends and acquaintances) may not be appropriate in another public context (a more formal social gathering). Understood this way, distinguishing between public and private concerns should center on the relationships in which information is transferred and the uses to which information is put. By relationships, I refer to the nature of the one's relationships with other people, social institutions, and the

208. See generally Helen Nissenbaum, Protecting Privacy in an Information Age: The Problem of Privacy in Public, 17 LAw \& PHIL. 559, 570 (1998) (arguing that being in public should not extinguish one's privacy interest).

209. Robert Post astutely points out that we cannot determine whether information is private "simply by examining the content of the information; we must instead have some notion of the circumstances surrounding the revelation of that information." Post, supra note 33, at 980. It may be "deeply inappropriate" for information to be revealed in a particular manner and time and to a particular audience. Id. at 981. Building upon these ideas, Paul Schwartz observes: "Different kinds of 'outing,' that is, revelation of otherwise fully or partially hidden aspects of one's life, should be prevented before different audiences." Paul M. Schwartz, Internet Privacy and the State, 32 CONN. L. REV. 815, 834-35 (2000). 
government. Personal information is gathered and disseminated within these relationships, and the propriety of disclosures relates to the relationships in which they occur. By uses, I refer to the purposes behind the disclosure. Information is disclosed for a particular reason or goal. Disclosure occurs through particular uses of information, and therefore, not all disclosures of information are the same.

An analysis focusing on relationships and uses must make reference to social norms, since they determine the appropriateness of a disclosure in a given context. Although a legal standard to distinguish public and private concerns must be moored in social norms, the standard does not always need to reflect what people actually do in practice. Norms are often aspirational. They do not merely reflect how people actually behave; they reflect how society thinks people should behave. These aspirational norms govern how society distinguishes between public and private concerns.

a. Relationships. If the law is to break free from simplistic attempts to demarcate the public and private spheres, it must begin to focus on the relationships in which the information is obtained and disclosed, and then consider the person or entity making the disclosure and to whom the disclosure is made. There are two relevant sets of relationships: (1) the original relationships in which the information is gathered, and (2) the relationships in which the information is disclosed. The former set of relationships involve the way the data was gathered. Was it gleaned by a stranger? Was it leaked by the police? Did a person's lawyer, doctor, or spiritual leader betray a confidence? Was the information obtained through theft or via illegal surveillance? The latter set of relationships involve the context in which the information is then disclosed. Was it disclosed on national television? Was it just told to one other person? To whom was it disclosed? Did the person to whom it was disclosed have a good reason to know it?

Suppose, for example, the information concerns a husband having an affair with another woman. Many people would believe that it is appropriate for the wife's brother to disclose the affair to the wife; they might even believe that the brother has a responsibility to do so. However, suppose the husband's doctor disclosed the information to the husband's employer or to government authorities. These scenarios are different because there are different norms that define these relationships. Not all people and entities have the same obligations in maintaining the confidentiality of information. As a 
matter of policy, there are significant differences regarding the desirability of certain people receiving the information.

In recognition of this reality, evidence law sometimes links information to the context in which it was gathered. In legal proceedings, evidentiary privileges restrict the disclosure of communications between attorney and client ${ }^{210}$ priest and penitent, ${ }^{211}$ husband and wife, ${ }^{212}$ and psychotherapist and patient. ${ }^{213}$ Often this information is highly relevant and probative. The law protects information communicated within these relationships even though it might be highly newsworthy and relevant to the trial. One might argue that these are contractual situations, but the law takes special steps beyond enforcing contractual rights to safeguard these relationships. Whereas contract law ordinarily cannot protect people from being compelled to testify in court, evidentiary privileges can. In this sense, although the information in people's relationships with their doctors and lawyers might interest others, evidence law recognizes the value of protecting that information from disclosure.

These insights from evidence law should be extended to the treatment of information disclosures in privacy law. Relationships differ in their level of intimacy, expectations of confidentiality, and power dynamics. Certain relationships have strong expectations of confidentiality, while others have weaker ones. For instance, what people reveal to employers differs from what they tell doctors, lawyers, religious leaders, and family members. Even within families, people may reveal different things to spouses, children, and parents. Certain relationships involve ethical obligations to maintain the confidentiality of information, and the parties generally know these obligations. By contrast, the obligations that a friend may have to maintain another friend's secrets are less clearly defined, even though many people would condemn disclosure. Other relationships do not involve any normative expectations of nondisclosure. Who would contend that a victim of a crime should not be able to discuss personal information about the perpetrator?

210. Upjohn Co. v. United States, 449 U.S. 383, 389 (1981).

211. See Glen Weissenberger, Federal EVIDENCE $§ 501.7$ (4th ed. 2001) (noting that the clergy-communicant privilege poses "very few problems in litigation" because it is "so widely and uniformly recognized").

212. Trammel v. United States, 445 U.S. 40, 45 n.5 (1980) (recognizing a "confidential marital communications privilege"); see also WEISSENBERGER, supra note 211, § 501.6 (discussing spousal privilege).

213. Jaffee v. Redmond, 518 U.S. 1, 9-10 (1996). 
As Anita Allen observes, people are accountable to others even in their private lives. ${ }^{214}$ Rarely do people's actions "concern only themselves." 15 However, this fact does not mean that one is accountable to everyone: "Accountability demands concerning private life may come from one's government, one's political community, one's employer, one's family, and even one's ethnic, racial, or religious group. Thus, sometimes people are held accountable, or feel accountable because of who and what they are." ${ }^{216}$ In other words, people are accountable within certain relationships, but rarely across the board. Assessing whether a disclosure is appropriate requires analyzing the relationship in which it occurs.

In many cases, the propriety of the disclosure of information also depends upon the manner in which it was obtained. Thus far, privacy law has suffered from too rigid and compartmentalized a focus. The privacy torts are overly carved up and have fossilized into rigid forms. Following Warren and Brandeis's article, courts feverishly created remedies for privacy harms. In 1939, the first Restatement of Torts recognized an invasion of privacy tort, but did not distinguish between different types of invasion. ${ }^{217}$ Ever since Prosser identified four distinct privacy torts in $1960,{ }^{218}$ the experimentation and growth of the privacy torts has slowed significantly. Now, each of the torts has a fairly fixed set of elements, often patterned after those defined by the Restatement (Second) of Torts in 1977.

Currently, the "public disclosure of private facts" tort focuses quite heavily on the nature of the information disclosed; the manner in which the information has been obtained is irrelevant. ${ }^{219}$ Instead, for this issue there is a separate tort, intrusion upon seclusion, which remedies "intrusions" upon one's "solitude or seclusion." ${ }^{, 20}$ Intrusion

214. Anita L. Allen, Why Privacy Isn't Everything: Feminist Reflections on Personal ACCOUnTABility 2 (2003).

215. Id.

216. Id. at 29-30.

217. Restatement of ToRTs $§ 867$ (1939); accord Linda N. Woito \& Patrick McNulty, The Privacy Disclosure Tort and the First Amendment: Should the Community Decide Newsworthiness?, 64 IOWA L. REV. 185, 190 (1979).

218. Prosser, supra note 10 , at 389.

219. See David A. Elder, The LAw of Privacy $§ ~ 3: 12$, at 216 n.61 (1991) ("[U]nlike intrusion upon seclusion, in public disclosure cases the issue of actionability and the public interest limitation should not turn on the matter in which the information has been obtained.") (internal quotation omitted).

220. RESTATEMENT (SECOND), supra note 11, § 652B. 
upon seclusion concentrates on the manner in which information is gathered; it does not look to the dissemination of the information. Thus, the privacy torts view the gathering of the information and the disclosure of information as completely separate matters, ignoring the interaction between these activities. ${ }^{221}$

As Paul Gewirtz argues, rather than looking to the content of the communication, the law could focus on "whether the original communication takes place within a protected zone.... The press could be sanctioned for publishing information about conversations within that zone, regardless of content." ${ }^{222}$ Gewirtz's approach focuses on how information is obtained. Public and private are not qualities that inhere in the information itself; rather, information is private if it exists in a private space. Even if the information is very intimate and highly embarrassing, it is public when located in a public domain or obtained via lawful means.

Under the protected zone approach, disclosure is prohibited for information obtained by breach of confidence, breach of contract, trespass, theft, or other violation of law. The protected zone approach was at issue in Bartnicki v. Vopper, ${ }^{223}$ which involved unlawful electronic surveillance. In Bartnicki, the president of a teachers' union and its chief negotiator were talking on a cell phone when one said: "If they're not gonna move for three percent, we're gonna have to go to their, their homes .... To blow off their front porches, we'll have to do some work on those guys." ${ }^{224}$ The call was intercepted in violation of the Electronic Communications Privacy Act (ECPA) of $1986,{ }^{225}$ and the person who intercepted the call gave a tape of the call to a reporter. There was good reason to believe that the reporter knew that the conversation was obtained illegally. The reporter broadcast the tape over the radio, and the caller sued him under the Act, which imposes liability when a person discloses a conversation "knowing or having reason to know" that it was obtained through an illegal interception under the Act. ${ }^{226}$ The Supreme Court held that the

221. See Rodney A. Smolla, supra note 158, at 321 (suggesting that the law of privacy would be strengthened if "there is an increasing 'convergence' between the intrusion and private facts torts").

222. Gewirtz, supra note 197, at 154-55.

223. 532 U.S. 514 (2001).

224. Id. at 518-19 (omission in original).

225. Electronic Communications Privacy Act of 1986, Pub. L. No. 99-508, 100 Stat. 1848 (codified as amended in scattered sections of $18,22,28,47$, and 50 U.S.C.).

226. 18 U.S.C. $\$ 2511(1)$ (c) (2000). 
Act was unconstitutional as applied in this case because "privacy concerns give way when balanced against the interest in publishing matters of public importance."227

Paul Gewirtz, disagreeing with the majority's analysis, argues that "[p]rivacy is ultimately about our power to choose our audience. When privacy is invaded, we are compelled to have an audience we do not want." 228 In Bartnicki, "the two people speaking on their cell phones did not wish to contribute to a public debate before a public audience. Their words were taken from them by stealth and put into public debate against their will." ${ }^{229}$

Gewirtz is correct that the Court was wrong to focus on the nature of the information rather than on how it was gathered. However, Gewirtz's focus on "protected zones" is far too broad. Looking to the "zone" in which people are communicating can be helpful, but it is an incomplete way to distinguish between speech of public and private concern. The problem in Bartnicki is not that a "zone" was invaded or that the parties did not want their conversation revealed to a public audience. Rather, the ECPA disclosure restriction at issue in Bartnicki concerns who is doing the gathering and disclosing of information, and the means of the information gathering.

The ECPA provision requires scienter-the person disclosing must know that the information is illegally obtained-and it does not apply to all information within a "protected zone." For example, if one of the parties to a conversation decided to speak about it to others, the ECPA provision would not apply. ${ }^{230}$ It applies only when the information is gathered in a particular manner-through electronic surveillance by a third party. Through this requirement, the ECPA forces examination of the relationship between the party gathering the information disclosed and the person to whom the information pertains. The ECPA provision also requires us to look at the relationship between the gathering and the disclosure of the information, in that the person who discloses the information must

227. Bartnicki, 532 U.S. at 514.

228. Gewirtz, supra note 197, at 155 .

229. Id. Rodney Smolla characterizes the information gleaned from the illegal wiretap as "contraband." Smolla, supra note 132, at 1099.

230. The law has long maintained that when we tell a secret to others, we assume the risk they will disclose it to others. See Daniel J. Solove, Digital Dossiers and the Dissipation of Fourth Amendment Privacy, 75 S. CAL. L. REV. 1083, 1136 (2002) (examining the line of Supreme Court cases developing this rule). 
have knowledge about its gathering. In short, the ECPA focuses on relationships among the people who communicate and who disclose information, not on particular zones in which communication or disclosure takes place. This provides a good example of the approach that the law should take in other contexts.

b. Uses. In addition to examining the relationships in which information is transferred, privacy law must also account for the uses to which it is put. Again, the rules of evidence provide a helpful model of how the law can consider the uses of information. For example, under the hearsay rule, an out-of-court statement cannot be entered into evidence to establish the truth of the matter asserted. ${ }^{231}$ However, it can be admitted as evidence of a person's state of mind. As such, the hearsay statement that "Mr. Doe was having an affair" is impermissible hearsay if used to prove that Mr. Doe was indeed having an affair, but it may be used to establish the state of mind of the person making the statement.

A focus on uses means that the law must examine the purpose of the disclosure, not just the nature of the information disclosed. The fact that the use of data is acceptable for a newspaper article does not mean that its use is acceptable in a database sold commercially or in credit reports. As Justice Powell observed for the Court's plurality in Dun \& Bradstreet, credit reports deserve less constitutional protection than other forms of free speech because credit reports are "speech solely in the individual interest of the speaker and its specific business audience." 232 In other words, credit reports are "low value" speech because of the purposes for which they are used.

Thus, focusing on uses rebuts Volokh's argument that all speech, including the transfer of information by database companies and the issuance of credit reports by credit reporting agencies, should be treated similarly. In essence, Volokh would equate these forms of speaking to disclosing the information in a news story. But as I have argued, because the uses are profoundly different, distinctions are possible even when the same information is involved.

Looking at uses yields more productive approaches for grappling with the question of what information is of public concern. For example, focusing on the use of identifying information in a media story often brackets the issue of whether an entire story is of public

231. FED. R. EVID. 801(c).

232. 471 U.S. 749, 762 (1985). 
concern; this makes it possible instead to examine whether the story truly needs to identify the parties involved. In other words, the story itself may be newsworthy, but the identification of the people involved might not further the story's purpose. In a number of wellknown cases, courts have so held. ${ }^{233}$ Barber v. Time, Inc. ${ }^{234}$ involved an article about a woman suffering from a rare disease that caused her to continue to lose weight, no matter how much she ate. The article was entitled "Starving Glutton," and it contained a photograph of the plaintiff in her hospital bed. The court correctly concluded that "[w]hile plaintiff's ailment may have been a matter of some public interest because unusual, certainly the identity of the person who suffered this ailment was not." ${ }^{, 235}$

One common argument against using initials or pseudonyms is that it erodes the credibility of an article. ${ }^{236}$ For example, in Howard $v$. Des Moines Register \& Tribune Co., ${ }^{237}$ the court concluded that the identities of victims of involuntary sterilization were essential to a report about abuses by a mental institution because the identities were needed to "strengthen the accuracy of the public perception of the merits of the controversy. ${ }^{" 238}$ In Gilbert v. Medical Economics Co. ${ }^{239}$ an article about the lack of self-policing in the medical profession disclosed the identity of a doctor involved in a malpractice case and revealed her photograph, as well as her psychiatric and marital problems. The court concluded that the identification of the plaintiff "strengthen[ed] the impact and credibility of the article" and eliminated "any impression that the problems raised in the article [were] remote or hypothetical." 240 Similarly, in Ross v. Midwest

233. Briscoe v. Reader's Digest Ass'n, 483 P.2d 34, 39-40 (Cal. 1971); Melvin v. Reid, 297 P. 91, 93 (Cal. Dist. Ct. App. 1931).

234. 159 S.W.2d 291 (Mo. 1942).

235. Id. at 295 .

236. Mintz, supra note 23, at 446-47; see, e.g., Barbieri v. News-Journal Co., 189 A.2d 773, 776-77 (Del. 1963) (using the name of the last man subject to corporal punishment in an article about the use of corporal punishment to deter crime was newsworthy and not an invasion of privacy); Poteet v. Roswell Daily Record, Inc., 584 P.2d 1310, 1312 (N.M. Ct. App. 1978) (disclosing the name of a fourteen-year-old kidnapping and sexual assault victim was newsworthy because it was a matter of public record, and thus not an invasion of privacy); see also Zimmerman, supra note 29, at 357 (recognizing the argument that editors of an article have a right to strengthen the force of their evidence by naming names).

237. 283 N.W.2d 289 (Iowa 1979).

238. Id. at 303 .

239. 665 F.2d 305 (10th Cir. 1981).

240. Id. at 308 . 
Communications, Inc. ${ }^{241}$ the court held that the disclosure of a rape victim's identity in an article about the possible innocence of the man convicted of the rape was of "unique importance to the credibility and persuasive force of the story." 242

I believe that all these cases were wrongly decided. In each case, the story could have been told without identifying the plaintiff. The story in Howard focused on the abuses of the facility; all that the story required were details of the abuses, not the names of the specific people involved. The story in Gilbert used the plaintiff as an example of a larger problem within the medical profession. Given the types of intimate details revealed about her, there seems to have lacked much connection between her specific identity and the problem of deficient self-policing. Finally, the innocence argument in Ross was based on the similarity of the rape to another rape involving a different alleged perpetrator. The identity of the victim was not an issue, given that the story did not focus on any acts of the victim.

In all cases, the courts relied on the argument that identification enhances the credibility of the story. However, this argument is at best weak. One might reply that identifying people in news stories is essential for the public to verify the stories independently. But, historically, stories of paramount importance have not identified the critical parties; for example, in exposing Watergate, Bob Woodward and Carl Bernstein relied on the well-known pseudonymous source, "Deep Throat." Certainly, it affects verifiability when a story does not identify a party. However, when the journalists protect confidential sources, they engage in a balancing determination, sacrificing the public's ability to verify for the importance of protecting confidentiality. Public verifiability is not sacrosanct, but can be outweighed by privacy interests.

Focusing on the use of a piece of information could lead to a significant change in the way journalists report certain stories. However, such an approach is not without precedent. Journalists generally do not include the names of rape victims or whistleblowers in their stories. On television, the media sometimes obscures the faces of particular people in video footage. With minimal effort, the media can report stories and also protect privacy.

The identification approach discussed above helps illuminate perhaps the most important First Amendment case involving

241. 870 F.2d 271 (5th Cir. 1989).

242. Id. at 274. 
disclosure protections-Florida Star v. B.J.F. ${ }^{243}$ In Florida Star, a newspaper published the name of a rape victim obtained from a public police report. The victim, who began to receive threatening telephone calls, had to move to a new address and undergo psychological treatment. She sued and prevailed under a theory that the newspaper was negligent per se because it violated a Florida law restricting the widespread disclosure of rape victims' names. ${ }^{244}$ However, the Court struck down the verdict, applying strict scrutiny under the First Amendment. ${ }^{245}$

Many have read Florida Star as a broad indication that restrictions on the disclosure of true information are unconstitutional. ${ }^{246}$ Nevertheless, this case can be read very narrowly. The Court suggested that the Florida statute was far too broad. ${ }^{247}$ The statute applied "regardless of whether the identity of the victim is already known throughout the community; whether the victim has voluntarily called public attention to the offense; or whether the identity of the victim [had] otherwise become a reasonable subject of public concern." ${ }^{248}$ The law focused only on the nature of the information, rather than on whether each particular use of a rape victim's name in a specific context would be of public or private concern. Florida Star can be construed to suggest that a law adopting

243. 491 U.S. 524 (1989)

244. The law provided: "No person shall print, publish, or broadcast, or cause or allow to be printed, published, or broadcast, in any instrument of mass communication the name, address, or other identifying fact or information of the victim of any sexual offense within this chapter." FLA. STAT. ch. 794.03 (1987).

245. Florida Star, 491 U.S. at 541.

246. See, e.g., id. at 550 (White, J., dissenting) (lamenting that the Court has all but nullified the public disclosure tort); Edelman, supra note 57, at 1207 ("The Court paid lip service to the possibility that a private-fact plaintiff may recover in some cases, but its decisions leave little hope for vindication of such a plaintiff's rights."); Phillip E. DeLaTorre, Note, Resurrecting a Sunken Ship: An Analysis of Current Judicial Attitudes Toward Public Disclosure Claims, 38 Sw. L.J. 1151, 1184 (1985) (stating the public disclosure tort has "become a phantom tort"); Joseph Elford, Note, Trafficking in Stolen Information: A "Hierarchy of Rights" Approach to the Private Facts Tort, 105 YALE L.J. 727, 729 (1995) (arguing that the public disclosure tort is "on the verge of collapsing under the weight of the First Amendment"); Jacqueline K. Rolfs, Note, The Florida Star v. B.J.F.: The Beginning of the End for the Tort of Public Disclosure, 1990 WIS. L. REV. 1107, 1128 ("Given the narrow class of information that fulfills the Florida Star requirements, the tort can no longer be an effective tool for protecting individual privacy."); Lorelei Van Wey, Note, Private Facts Tort: The End Is Here, 52 OHIO ST. L.J. 299, 300 (1991) (stating that the public disclosure tort "has been driven to near extinction").

247. In the lower court, the plaintiff did not recover directly under the statute. Rather, the court held the newspaper negligent per se. Florida Star, 491 U.S. at 528-29.

248. Id. at 539. 
a less categorical approach-by addressing the use of the identifying data more contextually_might not be subject to strict scrutiny under the First Amendment.

Not identifying persons involved in a story can resolve many of the tensions between privacy and free speech. Human interest stories can still be told while at the same time preserving the privacy of the individuals involved. The identification approach, however, will not work for all situations. In particular, when a story points out private information about a public figure, identifying the person involved is what gives the story its focus. These stories are not written to describe a unique situation or set of events, but are often written to inform readers about particular public figures. The question then becomes whether the story, as a whole, is of public concern.

For example, in Sipple v. Chronicle Publishing Company, ${ }^{249}$ Oliver Sipple foiled an attempt to assassinate President Ford when Ford was visiting San Francisco. The San Francisco Chronicle published an article outing Sipple as gay. Sipple sued under the public disclosure tort but the court rejected his claim, in part because the story was newsworthy. The court articulated two rationales: "to dispel the false public opinion that gays were timid, weak and unheroic figures and to raise the equally important political question whether the President of the United States entertained a discriminatory attitude or bias against a minority group such as homosexuals." ${ }^{250}$ If Sipple had not been identified to the public before the Chronicle's article, then the identification rule would suggest that the story could have simply not mentioned Sipple's name. But given that it was already known that Sipple was the one who saved Ford, protecting his identity would not have given him much meaningful privacy protection. Here, and with stories that involve public figures or limited public figures, the analysis must focus on the entire news story.

With regard to Sipple's story, Gewirtz contends that it was not newsworthy: "Given the intensely personal nature of Sipple's sexual identity and the care many homosexuals take to limit general knowledge about that identity, and given that Sipple did not seek notoriety, this asserted connection between the private fact and 'political considerations' was simply too weak to warrant the

249. 201 Cal. Rptr. 665 (Cal. Ct. App. 1984).

250. Id. at 670 . 
Chronicle's disclosure." 251 I disagree. My conclusion that the story is newsworthy is not based on an argument that Sipple had to be outed in order to promote better social images of gays. It is highly speculative and rather unlikely that outing one person could alter perceptions about gays. ${ }^{252}$ Rather, the story was newsworthy because it illuminated the president's potential prejudice. President Ford never called Sipple to thank him; nor did the president send Sipple a telegram. The article suggested that this "might not be just an oversight." ${ }^{253}$ What made the story newsworthy was not Sipple so much as President Ford. Pointing out the president's highly unusual behavior in failing to thank the person who saved his life, and raising the hypothesis that the omission was related to Sipple's homosexuality, involved an issue that is deeply connected to the political sphere. Information concerning the biases of public officials is an important political issue. Although speech of public concern is not necessarily limited to the sphere of politics, information used to address political issues will frequently be of public concern.

I reach my conclusion about Sipple by focusing on the use of the information. I do not argue that it would have been appropriate to disclose Sipple's sexual orientation merely to furnish a colorful story about the intriguing figure who rescued the president. But using the information is very appropriate when revealing details about the president's attitudes and prejudices. Even though the disclosure is the same in both instances, the use of the information is very different. ${ }^{254}$

One might reply that under an approach that focuses on uses, the media can simply rewrite articles so as to better connect the use of the information to a political purpose. This is certainly true, but doing so would still require the media to be more thoughtful about how a story contributes to matters of public concern. The media would be forced to think about alternative ways of telling the story. This might be a relatively modest development, but it would force the media to pay attention to some of the problems that it is creating, which alone might amount to a big first step.

251. Gewirtz, supra note 197, at 181.

252. See infra Part II(A)(3).

253. Sipple, 201 Cal. Rptr. at 666 n.1.

254. See John P. Elwood, Note, Outing, Privacy, and the First Amendment, 102 YALE L.J. 747, 776 (1992) (arguing that outing to establish a person as a gay role model should be outweighed by privacy rights, whereas outing to point out the hypocrisy of public officials should be permitted). 
In sum, evidence law focuses on the purpose for which information is used and the relevance of particular information to achieve permissible uses. This analysis should be extended to the task of distinguishing between public and private concerns. The terms "public concern" and "private concern" do not denote certain properties of particular types of information. Rather, they are a shorthand way of describing whether a disclosure is appropriate in a given situation. Thus, determinations of whether disclosure is appropriate should focus on the relationship in which the information is transferred. Certain types of relationships have particular normative expectations, and each type of relationship has different degrees of accountability. In addition to focusing on these relationships, the law must focus on how information gathered is used. Not all uses are the same. To assess whether the law should protect against certain disclosures, the law should examine the specific relationships and uses of the information, not whether the information fits into a category in the abstract.

In many instances, the contentious debate about whether a particular article raises matters of public or private concern can be sidestepped by examining whether the identifying information at issue contributes to the purpose of the article. This solution does not work in all instances, but it is an example of how certain debates can be shifted in more fruitful directions. Nevertheless, many disclosures require tackling head-on the question of whether the entire story is of public concern. This determination is bound to be messy, because there is no meaningful way to make it in a categorical fashion. As discussed throughout this Section, attempts to simplify the analysis lead to failure. Faced with this reality, critics such as Volokh contend that the free speech costs from a messy approach are far greater than the benefits. In the next Section, I attempt to answer this powerful contention.

3. The Problem of Hyper-Contextualism. A major problem with adopting a more contextual approach to distinguishing between public and private concerns is that the analysis can become too contextual. Without some guiding principles, the analysis can readily become a confusing and contradictory morass in which the central criteria remain unarticulated. For example, for the tort of public disclosure, Randall Bezanson argues that "standards of taste or 
propriety are simply unascertainable on a societal level" because society is "too pluralistic and culturally diverse." 255 Likewise, Diane Zimmerman contends that privacy is "rich in symbolic value but has little particularized meaning." ${ }^{256}$ There is a great difficulty in arriving at any social consensus on privacy: "It is difficult to achieve stable and serious agreement on the sort of personal information that can readily be foregone, and which disclosures are therefore 'unreasonable.",257 Eugene Volokh contends that standards such as "lack of legitimate public concern" are "so vague and potentially so broad that accepting them may jeopardize a good deal of speech that ought to be protected." ${ }^{258}$ Likewise, Thomas Emerson argues that defining "newsworthy" as involving matters of "public interest" is quite "vague" because it fails to determine "what is or what ought to be a matter of public interest." ${ }^{, 259}$ If social norms about the propriety of disclosures are too diffuse and contestable, then a law protecting against "improper" disclosures may become too unpredictable or even unworkable.

I do not share this skepticism about finding a sufficient degree of social consensus on privacy. Social consensus can and does develop on a number of specific matters, such as the lack of legitimate public interest in nude pictures of unwilling private individuals. ${ }^{260}$ However, in all but the most extreme cases, it will be difficult to find a social consensus. In our pluralistic society, few values will have the level of consensus that scholars like Volokh demand. Nevertheless, the law does not simply reflect social values; it also shapes them, and over time it can help build some degree of social consensus. When members of society disagree, the law forces society to weigh competing values. Prohibiting the law from distinguishing between matters of public and private concern will not result in neutrality but in certain values prevailing over others. The balance established in the absence of law's involvement may not be the most beneficial to society.

255. Bezanson, supra note 27, at 1172 .

256. Diane Leenheer Zimmerman, Musings on a Famous Law Review Article: The Shadow of Substance, 41 CASE W. RES. L. REV. 823, 826 (1991).

257. Id.

258. Volokh, supra note 32, at 1116.

259. EMERSON, supra note 35, at 553.

260. See, e.g., Comment, An Accommodation of Privacy Interests and First Amendment Rights in Public Disclosure Cases, 124 U. PA. L. REV. 1385, 1411 (1976) ("[S]ociety defines by convention some of the areas considered most private."). 
As discussed earlier, the media does not necessarily develop norms that are socially optimal, and neither do database marketers and credit reporting agencies. Thus, there are benefits to allowing judges and juries to decide cases in a contextual manner. Through precedent, which serves to limit the degree of variation and inconsistency in cases, judicial involvement enables the growth and development of standards for weighing conflicting and contested values. Certainly, juries do cause some variation. However, over time, judges define parameters and reach points of widespread consensus. ${ }^{261}$ Similar consensus is developing about privacy, although the tort of public disclosure is much younger than most other torts. Warren and Brandeis recognized this problem in their article, and they responded:

There are of course difficulties in applying such a rule; but they are inherent in the subject-matter, and are certainly no greater than those which exist in many other branches of the law,-for instance, in that large class of cases in which the reasonableness or unreasonableness of an act is made the test of liability. ${ }^{262}$

Therefore, the existence of a complex standard as opposed to a clear rule is not necessarily a problem. An extensive literature discusses the benefits of vague standards over clear rules, of "muddy" versus "crystalline" law. ${ }^{263}$

It is true, however, that a contextual approach toward distinguishing public and private concerns will have some chilling effects on speech. While Volokh contends that the chilling effects will be great and that the privacy interests are relatively unimportant, I have argued that privacy is too important to ignore because it strongly promotes the interests justifying free speech. Volokh argues that the privacy arguments are overblown because they often assume a situation in which privacy is completely annihilated: "Claims about

261. Such a consensus is beginning to be shaped in the law of editorial judgment. See Randall P. Bezanson, The Developing Law of Editorial Judgment, 78 NEB. L. REV. 754 (1999).

262. Warren \& Brandeis, supra note 8, at 214.

263. See, e.g., Edward J. Janger, Muddy Property: Generating and Protecting Information Privacy Norms in Bankruptcy, 44 WM. \& MARY L. REV. 1801, 1878 (2003) ("[Vague] propertybased entitlements... are a promising approach that should have the happy consequence of establishing courts as guardians of information privacy."); Marc R. Poirier, The Virtue of Vagueness in Takings Doctrine, 24 CARDozo L. REV. 93, 191 (2002) ("[F]aith and hope, and not a little charity, are the hidden message, the underlying virtue of the vagueness in takings doctrine."); Carol M. Rose, Crystals and Mud in Property Law, 40 StAn. L. REV. 577, 610 (1988) ("[Vague] rhetoric suggests that we treat even those to whom we have no real connection with the kind of engagement that we normally reserve for friends and partners."). 
what would happen if privacy were totally destroyed tell us nothing about which particular privacy rules ... are indispensable." ${ }^{264}$ Although arguments based on the total destruction of privacy are sometimes made, they are often ineffective because they are too abstract and speculative. These arguments aim to shock by revealing the bleak bottom of the slippery slope. Therefore, on this point, I agree with Volokh - but only to a certain extent. As Volokh argues in a recent article about slippery slope arguments: "We can't just dismiss slippery slope arguments as illogical or paranoid, though we can't uncritically accept them, either." ${ }^{265} \mathrm{He}$ notes that certain policy decisions can alter attitudes, "leading [people] to accept proposals that they would have rejected before." 266 One of the rationales for protecting privacy is to prevent slipping down the slope to a world in which people expect less privacy, and privacy continues to evaporate until little remains. This threat need not be exaggerated, but it should not be ignored.

Indeed, the same type of argument is sometimes made about free speech: that a relatively modest limitation on free speech will lead down the slippery slope to greater restrictions. Indeed, Volokh expresses concern over the "possible downstream effects" of privacy restrictions on disclosure, arguing that making exceptions for privacy "will be a powerful precedent for those other restraints and for still more that might be proposed in the future." 267 This is the danger of the slippery slope - if true statements about people can be restricted, what will stop other restrictions? $?^{268}$

Nevertheless, Volokh has not demonstrated that disclosure protections actually lead to diminished protection for free speech in other areas. At best, Volokh's argument is speculative, which in and of itself is not a basis to reject it. Many disclosure protections, however, are not new. The public disclosure tort has existed for much of the twentieth century, and it has not cowed the media. Thus, it does not appear at this point that disclosure protections have led to further speech restrictions.

264. Volokh, supra note 32, at 1111.

265. Eugene Volokh, The Mechanisms of the Slippery Slope, 116 HARV. L. REV. 1026, 1136 (2003) (footnote omitted).

266. Id. at 1036.

267. Id. at 1051.

268. Id. at 1114. 
The distinction between public and private concerns cannot escape some fuzziness, but there are different levels of fuzziness: fuzziness throughout, and fuzziness at the margins. In other words, as with any distinction, there are bound to be some black-and-white areas and some gray areas. The critical question is not whether or not there is some gray, but where the gray zone is located and how large it is. The danger of gray spots is that there will be chilling effects around these places. Robert O'Neil points out that the fear and cost of litigation may result in the media being overly cautious and failing to report on certain important stories. ${ }^{269}$

Under my approach, not all stories will have the same risks of being chilled. Human interest stories might be chilled, but, in most cases, the only chilling will be of specific identifying information - the names of the people involved. In other words, the chilling effect argument is often overbroad. The chilling effect argument achieves its power by envisioning the media inhibited in its role of watchdog and protector of democracy. But the watchdog character of the press is unlikely to be chilled. There are many stories that most people can readily agree are of public concern, such as stories about political elections, health care policy, foreign affairs, the war on terrorism, and so on. It is the media's dark underbelly-reporting on the latest celebrity scandal - that will be in the gray zone and might be chilled. And this consequence is not as terrible as the free speech critique proponents make it out to be. Why should the media be allowed to do whatever it wants, no matter how socially detrimental or harmful to individuals, no matter how great the costs to others in society, no matter how few the benefits produced? The media should internalize some of the costs that it imposes on others in making its product. Sadly, the media have often become more of a watchdog to celebrities than to the government.

My argument for a contextual approach to distinguishing public from private is not one that always prefers a resolution by judges or juries. Although legislatures cannot be quite as contextual, they can still pass laws that focus on the relationships surrounding the information-how it is obtained, disclosed, and used. There are many

269. See O'NEIL, supra note 10, at 167 ("[T] he potential legal risks outweighed whatever benefit might result from broadcasting such material."); see also BRUCE W. SANFORD, DON'T Shoot the Messenger: How Our Growing Hatred of the Media Threatens FreE SPEECH FOR ALL OF Us 1-10 (1999) (recounting examples of corporations and celebrities' suing to restrict stories and the media's "caving" in). 
circumstances in which the privacy torts are not adequate to protect privacy, as is the case with the use of personal information in computer databases. Elsewhere, I argue that the privacy torts are not effective in grappling with the growing collection and use of personal data in computer databases because the torts focus on individual cases when the problems of databases are more systemic. ${ }^{270}$ Statutory law works best in many circumstances that raise systemic problems. As Julie Cohen argues: "[I]t is becoming increasingly clear that the common law invasion of privacy torts will not help to contain the destruction of informational privacy." 271

Privacy law is still relatively young. It has not simmered for centuries like much of tort law or criminal law. An extensive amount of work must be done to mature this area of law, and prudence counsels avoiding the temptation to reach for easy bright-line rules. There is no easy bright-line approach to resolving how public and private concerns can be distinguished. I have demonstrated that approaches attempting to do so have failed. Despite the impossibility of making a tidy distinction, a distinction is still possible-although it will be messy at times. My suggestion to focus on relationships and uses aims to reshape the debate about how to draw this distinction. Although my approach will not bring easy answers, I hope it will prevent the law from reaching faulty ones. In any event, having the debate over public and private speech is critically important to society. As I have demonstrated in Section B, and as I endeavor to show in Part II, privacy is too important a social value to be sacrificed for greater clarity and certainty in First Amendment doctrine.

\section{Reassessing the Free Speech Critique}

Broadly, my purpose has been to argue against Volokh's approach of applying strict scrutiny to most privacy protections. ${ }^{272}$ Volokh's approach has the virtue of simplicity; it is much less messy, and it has less potential to chill speech than the alternative approach I have sketched. Nevertheless, despite these virtues of Volokh's

270. Solove, supra note 5, at 1434-35; see also Stan Karas, Privacy, Identity, Databases, 52 AM. U. L. REV. 393, 441-42 (2002) ("Although individual bits of data in the consumer profile are as inconclusive as those in Shibley, their aggregation and juxtaposition represent a qualitatively different kind of threat to privacy.").

271. Cohen, supra note 141, at 2043.

272. Rodney Smolla makes an interesting argument when he contends that tying disclosure restrictions to content "arguably enhances First Amendment values more than it detracts from them, by employing greater precision in regulation." Smolla, supra note 132, at 1151-52. 
approach, and despite the potential for messiness and chilling effects in my approach, the case for privacy is strong. The reason is that, on balance, privacy furthers many of the same interests that free speech does.

Debates about free speech are sometimes cast in absolutes. However, not all speech is of equal value, nor is speech a value superior to all others. It is imperative to balance. Balancing means assessing the value of particular forms of speech against their costs. I have argued that speech about private matters should be given less weight than speech about public matters. The determination of what is public and what is private should not rest with the media, for this would leave the decision in the hands of decisionmakers who can be flawed and self-interested. Likewise, focusing on the status of the individual (public versus private figures) as well as looking at the nature of the information disclosed both fail to account adequately for context. These approaches see disclosure as all or nothing. Either information is of private concern and remains wholly secret, or it is of public concern and can be released to the world for whatever reason. But this all-or-nothing approach is not very workable in an age when information has so many uses and can be disseminated and stored so easily. It is wiser to avoid speaking of information as if it is private or is public. Often, the same piece of information is of both private concern and public concern-it just depends upon the context. And by "context," I mean the relationships in which information is transferred and the uses to which information is put. Information is typically generated and recorded for a particular reason. It originally exists in particular relationships, with particular meanings and expectations of dissemination and use. Disclosures take information beyond these initial contexts, moving it into new contexts and new relationships, for new purposes. The law must focus on uses of information, not on categorizing a particular piece of information as public or private. Different uses of the same piece of information have different benefits and different costs. The law of evidence readily recognizes this reality; the law of privacy could benefit from a similar approach.

Under the theories supporting the value of free speech discussed above, disclosure protections generally fare well in the balance. There are many good reasons why society values free speech and wishes to protect it. Instrumentally, free speech is valuable because it promotes autonomy, democracy, and the quest for the truth. But these interests can also be served by protecting privacy, and a balance between free 
speech and privacy might achieve these interests more effectively than merely protecting speech at all costs.

Nevertheless, the importance of privacy must be better articulated. As discussed earlier in this Section, privacy promotes First Amendment interests and can protect free speech. But it has other benefits, which I discuss in Part II.

\section{The JudgMENT AND TRUST CRITIQUE}

The free speech critique focuses on a particular set of values for the free flow of information. Another critique of disclosure restrictions, which I call the "judgment and trust critique," locates the value of free flow of information in the way it contributes to people's ability to judge others, place trust in others, and educate themselves about society. Under the judgment and trust critique, protections against disclosure inhibit a person's ability to assess other people's reputations and make accurate judgments about them.

According to Judge Richard Posner, protection against disclosure impedes people's ability to make judgments about other people. He views the central issue in privacy law as "whether a person should have a right to conceal discreditable facts about himself.,"273 "The economist sees a parallel to the efforts of sellers to conceal defects in their products." ${ }^{274}$ Posner views privacy as a form of selfinterested economic behavior-it lets people conceal harmful facts about themselves for their own gain. ${ }^{275}$ Specifically he observes that "when people today decry lack of privacy, what they want, I think, is mainly something quite different from seclusion: they want more power to conceal information about themselves that others might use to their disadvantage." ${ }^{276}$ A person constructs a public self to display to the world, and then sells this self by "using it to make advantageous transactions in employment and marriage markets and, more generally, in the market for human relationships whether of a personal or of a commercial character."277 Likewise, Richard Epstein

273. POSNER, supra note 30 , at 46.

274. Id.

275. Richard A. Posner, The Economics of Justice 234 (1981) (people "want to manipulate the world around them by selective disclosure of facts about themselves.").

276. Id. at 271.

277. Richard A. PoSNER, OVERCOMING LAW 532 (1995). 
contends that "the plea for privacy is often a plea for the right to misrepresent one's self to the rest of the world." 278

The judgment and trust critique also assumes that more disclosure will generally yield more truth. In other words, more information about a person will make one's judgment about that person more accurate. For example, when a person knows about the defects in a product, the person is able to value that product more accurately. As with all products, Posner argues, more truthful information enables more informed decisions. "Prying enables one to form a more accurate picture of a friend or colleague, and the knowledge gained is useful in social or professional dealings with him. ${ }^{\text {279 }}$ Under Posner's view, much secrecy is deception:

We would think it wrong (and inefficient) if the law permitted a seller in hawking his wares to make false or incomplete representations of their quality. But people "sell" themselves as well as their goods by professing high standards of behavior to induce others to engage in advantageous social or business dealings with them, while concealing facts that these acquaintances need in order to evaluate their character. ${ }^{280}$

Thus, according to Posner, privacy can be a form of deception which benefits the individual at the expense of many others.

There is certainly a strong social value in enabling people to make accurate assessments of others. According to sociologist Steven Nock, "[t]rust and the ability to take others at their word are basic ingredients in social order." 281 People often establish trust based on a person's reputation, which is "a shared, or collective, perception about a person." 282 Today, most people no longer live in small towns where they know personally nearly everyone in their lives. Instead, people tend to live in large communities with highly mobile populations, in which many neighbors are strangers. ${ }^{283}$ Privacy inhibits the establishing of trust because privacy "makes it difficult to know others' reputations," and knowing reputations is a prerequisite to

278. Epstein, supra note 30, at 12 .

279. POSNER, supra note 275 , at 232.

280. Id. at 233 .

281. Steven L. Nock, The Costs of Privacy: Surveillance AND Reputation IN AMERICA 1 (1993).

282. Id. at 2 .

283. See id. at 11-12 (discussing the increase in strangers, and therefore of privacy, as a function of urbanization and social mobility). 
trusting strangers. ${ }^{284}$ We place our safety in the hands of other people. We entrust others with our finances, our deepest secrets, and the care of our children. Disclosures of personal data provide the information necessary to determine whether or not to trust other people.

Even when information is not helpful in judging the particular people with whom one interacts, gossip about people's private lives can serve an educative function, enabling people to learn about the lifestyles of others. Because private lives play an important role in daily existence, learning about the private sphere is very valuable. Contrary to Warren and Brandeis' dismissal of gossip as being idle and trivial, Diane Zimmerman contends that gossip has a high social value: "By providing people with a way to learn about social groups to which they do not belong, gossip increases intimacy and a sense of community among disparate individuals and groups." ${ }^{285}$ Zimmerman's argument takes the judgment and trust critique a step beyond one's immediate circle. By her account, disclosure not only helps people to judge those with whom they associate, but also facilitates a more general understanding of human nature.

In this Part, I respond to the judgment and trust critique. First, I contend that disclosure often does not improve judgment. Personal information taken out of context can lead to hasty and unfair judgments that do not necessarily lead to more truth about a person's character. Disclosure protections also safeguard against certain irrational judgments. Additionally, disclosure protections guard against rational judgments that society may desire to curtail. Regarding the educative function of gossip, I contend that its value is thin; to whatever extent gossip can educate people about society, less harmful alternatives exist to achieve the same end. I then respond to two replies - that disclosure protections to further these ends are paternalistic, and that they promote too much dissonance between public and private identities.

Second, I argue that even if a disclosure of private information improves the accuracy of judgments, it can still be outweighed by other social interests, such as promoting the ability to grow and to reform. In responding to the judgment and trust critique, I point out that the critique often improperly focuses on information in the abstract, without attending to its purpose or potential use. I argue that categorical judgments are often flawed; it is more fruitful to focus on

284. Id. at 124 .

285. Zimmerman, supra note 29, at 333-34. 
how the information will be used. Refashioning the inquiry in this way reveals that many disclosures are far too broad for their purposes, and that disclosure regulations can help to achieve a better tailoring between disclosures and the sometimes worthy ends for which they are made.

\section{A. Less is More?}

The judgment and trust critique has a strong intuitive persuasiveness. This is because most people would generally agree that more information is preferable to less. Most people would also agree that judgments about others are generally enhanced and improved by more information. More disclosure, however, may not necessarily lead to more accurate judgments about others. In this Section, I explain that the disclosure of private information can often lead to misjudgment, and I argue that the law can and should influence the way people judge each other.

1. Judging Out of Context. Posner analogizes discreditable private information about people to unfavorable information about commodities. However, the "truth" about a person is much more difficult to ascertain than the truth about a product or thing. People are far more complex than products. Knowing certain information can distort one's judgment of another rather than increase its accuracy.

Judging other people is a very important ability. People constantly asses those around them, which facilitates interpersonal interaction, trust, and comprehension. But people often judge quickly because of time constraints. Jeffrey Rosen astutely points out that people have short attention spans and will likely not judge other people fairly: "Privacy protects us from being misdefined and judged out of context in a world of short attention spans, a world in which information can easily be confused with knowledge." ${ }^{286}$ Rosen further argues:

When intimate personal information circulates among a small group of people who know us well, its significance can be weighed against other aspects of our personality and character. By contrast, when intimate information is removed from its original context and

286. Jeffrey Rosen, The Unwanted Gaze: The Destruction of Privacy in AMERICA 8 (2000). 
revealed to strangers, we are vulnerable to being misjudged on the basis of our most embarrassing, and therefore most memorable, tastes and preferences. ${ }^{287}$

Our perception of the world is riddled with gaps. William Gass, writing about literature, observes:

Characters in fiction are mostly empty canvas. I have known many who have passed through their stories without noses, or heads to hold them; others have lacked bodies altogether, exercised no natural functions, possessed some thoughts, a few emotions, but no psychologies, and apparently made love without the necessary organs. ${ }^{288}$

Similarly, the narratives about others that people construct are often filled with "empty canvas"-imagination must fill in the gaps.

Human judgment is imperfect, unfair, and often uncompromising. People often condemn others on partial information. Indeed, necessity demands hasty judgment. If it is true that human judgment is generally hampered by short attention spans and incomplete information, why should the law pay special attention to misjudgment based on private rather than public information? Lawrence Lessig agrees with Rosen that privacy protects people "from damaging conclusions drawn from misunderstood information" due to the fact that people have a limited attention span for learning the complete story. ${ }^{289}$ But Lessig criticizes Rosen's argument because the problem of limited attention spans "is more general than privacy. Privacy could be one solution to a more general failing of the information market. But it will not, on its own, solve this problem with the information market. ${ }^{, 290}$ Robert Post also critiques Rosen on similar grounds, arguing that the problem of misunderstanding is not really a privacy problem because misunderstanding can occur with both private and public information. ${ }^{291}$ Why is protecting private information special?

Lessig and Post are correct that misunderstanding can occur in many ways, not exclusively through revelation of private information.

287. Id. As Julie Cohen observes: "The harms of this rush to judgment ... may undermine liberal individualism (as Rosen argues), but they are products of it as well." Cohen, supra note 141 , at 2030.

288. William H. Gass, Fiction AND THE Figures OF LiFE 45 (1979).

289. Lawrence Lessig, Privacy and Attention Span, 89 GEO. L.J. 2063, 2065 (2001).

290. Id. at 2066.

291. Robert C. Post, Three Concepts of Privacy, 89 GEO. L.J. 2087, 2087-89 (2001). 
Just because this is so, however, need not tarnish Rosen's insight. Much misunderstanding occurs because of the disclosure of private information, and therefore, privacy is an important way of protecting against misunderstanding. It may not be the exclusive way to safeguard being judged out of context, but there are many reasons why the disclosure of private information is particularly susceptible to misunderstanding.

An additional way that privacy laws have mitigated the problem of judging out of context is by helping people to mediate among the different types of roles they must play in society. Drawing from the work of sociologist Erving Goffman, ${ }^{292}$ Alan Westin argues that individuals need to control information about the self because they have conflicting roles to play in society and must present different selves at different times:

Each person is aware of the gap between what he wants to be and what he actually is, between what the world sees of him and what he knows to be his much more complex reality.... Every individual lives behind a mask in this manner; indeed, the first etymological meaning of the word "person" was "mask," indicating both the conscious and expressive presentation of the self to a social audience. If this mask is torn off and the individual's real self bared to a world in which everyone else still wears his mask and believes in masked performances, the individual can be seared by the hot light of selective, forced exposure. ${ }^{293}$

Different roles have different norms about how to relate to others. ${ }^{294}$ For example, parents present themselves as role models to their children, and society deems it quite appropriate for parents to portray themselves in this idealized manner.

Each role enables people to display different aspects of themselves. People even play roles in which they seem improperly cast, hoping to grow into the part. One plays a role until it fits, becoming transformed in the process. Selfhood is a process of growth and development, not a fixed state of being.

The self has public and private dimensions. These two modes of existence can be vastly dissimilar, requiring different behaviors and self-expression. No one can be purely public or purely private. As

292. ERving Goffman, The Presentation of Self In EVERyday Life (1959).

293. WESTIN, supra note 104, at 33; see also Karas, supra note 270, at 428-29.

294. Cass R. Sunstein, Social Norms and Social Roles, 96 COLUM. L. REV. 903, 922 (1996). 
novelist Milan Kundera observes, "[a]ny man who was the same in both public and intimate life would be a monster. He would be without spontaneity in his private life and without responsibility in his public life." ${ }^{295}$

Public roles require the repression of private aims to meet the expectations of others. ${ }^{296}$ People groom themselves and clothe themselves before emerging in public, and when playing public roles they are careful in how they foster impressions. In private roles, the individual expresses aspects of the self that are often inappropriate in public roles. ${ }^{297}$ In private, people are generally more relaxed and at ease. As Kundera notes: "[I]n private, a person says all sorts of things, slurs friends, uses coarse language, acts silly, tells dirty jokes, repeats himself, makes a companion laugh by shocking him with outrageous talk, floats heretical ideas he'd never admit to in public, and so forth., ${ }^{298}$

There is a popular myth that the public self is not as real or genuine as the private self, but this is not necessarily the case. Indeed, to the ancient Greeks, according to Hannah Arendt, public life was more representative of one's authentic self than life in private. ${ }^{299}$ I posit that neither the public nor private self represents the true self; these are just dimensions in a very complex multifaceted personality, one that is shaped by the roles a person plays. People express different sides of their personalities in different relationships and contexts.

If one accepts this account of selfhood, then it follows that disclosures about people in one context will not necessarily reveal who they "truly" are or enable more accurate assessments of their character. Instead, these disclosures can often be jarring, for they display people out of the particular context in which others may know them. For example, an introverted and conservative person may have a fantasy life on the Internet, where she becomes outgoing, bold, and experimental. Suppose she participates in a chatroom on bondage. Does this information, when disclosed to her coworkers and friends, enable them to better assess who she really is as a person? One could

295. Roth, In Defense of Intimacy: Milan Kundera's Private Lives, THE Village Voice, June 26, 1984, at 42, col. 1.

296. Joseph Bensman \& Robert Lilienfeld, Between Public and Private: Lost BOUNDARIES OF THE SELF 174 (1979).

297. Id. at 49 .

298. Milan Kundera, Testaments Betrayed 260-61 (1995).

299. HANNAH ARENDT, THE Human CONDITION 22-24 (1958). 
argue that any incremental information enhances one's ability to assess others. Seeing people across contexts can lead to a more complete overall assessment of character. However, isolated information, often constituting only part of a very complicated reality, may lead to hasty condemnation.

Disclosures of private information at the initial stages of acquaintance can be even more distorting. According to Goffman, people need time to establish relationships with others before revealing secrets. ${ }^{300}$ Immediate honesty is costly. With time to gain familiarity with an individual, people are better able to process information, see the whole person, and weigh secrets in context. ${ }^{301}$

Rosen argues that apprehensiveness about misjudgment based on private information can impede people's ability to form intimate relationships:

If individuals cannot form relationships of trust without fear that their confidences will be betrayed, the uncertainty about whether or not their most intimate moments are being recorded for future exposure will make intimacy impossible; and without intimacy, there will be no opportunity to develop the autonomous, inner-directed self that defies social expectations rather than conforms to them. ${ }^{302}$

In other words, the disclosure of private information can corrode our private roles.

There is another reason for protecting against the disclosure of private information: it hinders not only private roles but public roles as well. Everyone must cope with the fragility of reputation, on which the ability to function in society delicately hangs. All who value their reputations care about how others judge them. Reputation is especially important in one's public roles, because these roles shape one's career, relationship with much of society, participation in political life, and financial well-being. The reality is that people lack much control over how they are judged. One is constantly at the mercy of others-a precarious position to be in. However, managing disclosures about one's private life is an even greater and more difficult burden, making reputation all the more vulnerable.

300. ERVING Goffman, Stigma: Notes on the MANAGEMENT OF SPOILED IDENTITY 96 (1963).

301. Id.

302. Jeffrey Rosen, The Purposes of Privacy: A Response, 89 GEO. L.J. 2117, 2123-24 (2001). 
Society accepts that public reputations will be groomed to some degree. People are often careful to keep their public reputations free of dirt and grime. Because it is possible to separate out certain aspects of life as private, and because people can prevent information about their private lives from reaching the public, people can exercise some amount of control over how others judge them in public. Society protects privacy because it wants to provide individuals with some degree of influence over how they are judged in the public arena. Although no one is secure from all misjudgment, privacy also allows people to foster certain contexts in which they are free from having to worry about public misjudgment.

Why is it important to protect the way one is judged? I posit that such protections are important because concerns about being misjudged and having one's reputations poisoned can make people profoundly unfree, shackling them to their perceptions of how they will be perceived. Of course, people manufacture their public reputations quite a bit. Posner would say that by protecting privacy, society is enabling people to promote misjudgment in ways that are favorable to privacy-seekers and detrimental to those who would seek to judge them. However, the degree of control that privacy affords people over how others judge them brings important benefits-it helps them to feel more confident in the public sphere, participate in public activities more freely, and play private roles with more gusto. Being judged by others is an inescapable reality of living in society. It can be helpful and instructive, for the way we are judged by others helps us shape our identities and can make us aware of our identities, good qualities, and flaws. But judgment can also become oppressive and suffocating, a danger which privacy mitigates.

The law protects against disclosures of private information because society believes that such information is not appropriate for making public judgments about people. Without making a distinction between public and private information, it is hard to think of a viable way to give people any limited control over how others judge them. If the law protected against the disclosure of all information that could lead to judging out of context, it would have to limit the disclosure of practically all personal information. That clearly is unworkable, so the law recognizes limited contexts (the private sphere) in which to protect against disclosures.

In sum, disclosure protections are justified not only because private information will lead to judging out of context, but also because of the value of preserving partial control over how people are 
judged and enabling some limited degree of freedom from the harsh and often unfair judgments that everyone regularly encounters in public. Because the disclosure of private information will not necessarily result in more accurate judgments, the benefits of disclosure protections can often outweigh the costs.

\section{The Trouble with Irrational-and Rational-Judgment.} Besides judging based on partial information, people are also prone to making irrational judgments. Certain traits and conditions carry great stigma, which is often the result of incorrect assumptions and faulty knowledge. According to Goffman, stigma is "an attribute that is deeply discrediting." ${ }^{303}$ Certain stigmatic facts about a person include addiction, alcoholism, suicide attempts, mental disorders, unemployment, and illiteracy. Society does not fully accept people with stigma; they are not treated equally. ${ }^{304}$ Stigma can spread to family members, as when children feel stigmatized by a parent's criminal past. ${ }^{305}$ Although there are instances in which stigma is properly attached to certain conditions, in other cases, it impedes accurate judgment.

People protect certain secrets because disclosure might lead to irrational behavior, such as stereotyping and discrimination, toward them and their families. For much of history, there were widespread beliefs that people who contracted particular diseases did so because of their character flaws. ${ }^{306}$ Even education has a difficult time cleansing stigma. During the cholera epidemic of 1866, when cholera was understood to derive from poor sanitation, people still clung to the belief that the disease was "the scourge of the sinful." ${ }^{307}$ People with noninfectious illnesses, such as cancer, still find themselves shunned by friends and family. ${ }^{308}$ Susan Sontag contends:

Nothing is more punitive than to give a disease meaning-that meaning being invariably a moralistic one. Any important disease whose causality is murky, and for which treatment is ineffectual, tends to be awash in significance. First, the subjects of deepest dread

\footnotetext{
303. GOFFMAN, supra note 300 , at 3 .

304. Id. at 7-9.

305. Id. at 30 .

306. SUSAN SONTAG, ILLNESS AS METAPHOR 38 (1978).

307. SusAn SONTAG, Illness AS MetaPHOR AND AIDS AND ITS METAPHORS 143 (1990).

308. SONTAG, supra note 306, at 6 .
} 
(corruption, decay, pollution, anomie, weakness) are identified with the disease. The disease itself becomes a metaphor. ${ }^{309}$

Furthermore, the disclosure that people have certain diseases engender assumptions about them. Disclosure that a person has AIDS often results in speculation that a person has engaged in drug use, promiscuous sex, or homosexual sex. ${ }^{310}$

Posner and Epstein believe that the market will correct for such irrationalities in judging. ${ }^{311}$ Irrational judgment has opportunity costs because shunned people may be good workers and can be hired for below-average wages. Thus, in "a competitive society, irrational shunning will be weeded out over time." 312

However, this theoretical prediction does not match the current reality. Several surveys reveal that many employers have incorrect views of cancer's effects and treatment, and cancer patients lose their jobs five times more frequently than employees without cancer. ${ }^{313}$ Further, employers can often discriminate without feeling significant repercussions. If only a small percentage of workers have the particular stigmatic condition, then there will be little market incentive not to behave irrationally. Unless such employers are forced out of business or the economic consequences are severe, discrimination is likely to continue. Additionally, irrational judgments have existed throughout human history and continue to exist. Even in the face of high costs, employers continue to engage in irrational racial and other forms of discrimination. Market pressure cannot always rectify strongly held beliefs or subconscious prejudices. ${ }^{314}$

Even if the market could correct all irrational judgments, many socially undesirable judgments about others based on private information are rational. As Julie Cohen notes, judging others out of context is often "the logical product of rational self-interest.","15 Genetic discrimination in the workplace can be a rational decision,

309. Id. at 58 .

310. Karas, supra note 270, at 427.

311. POSNER, supra note 275, at 235; Epstein, supra note 30, at 18 ("Employers have no incentive to discriminate against workers whose genetic conditions do not impose any cost, present or future, against them.").

312. POSNER, supra note 275, at 235.

313. Schwartz, supra note 33, at 29.

314. See, e.g., Richard H. McAdams, Cooperation and Conflict: The Economics of Group Status Production and Race Discrimination, 108 HARV. L. REV. 1003 (1995) (reviewing marketbased theories of racial discrimination).

315. Cohen, supra note 141, at 2033. 
for an employee with a genetic predisposition for certain diseases will be at greater risk to become unproductive in the future. ${ }^{316}$ Even if employers might rationally decide not to hire a worker based on genetic information, society might want to restrict employers from making such decisions. One reason, as Pauline Kim notes, is that such decisions implicate personal autonomy.

Work in our society represents more than merely an income stream; it is closely tied to identity, status and community. Foreclosing a substantial number of employment opportunities not only limits individuals' potential earning power, it also deprives them of critical choices through which one creates an identity and builds a life. ${ }^{317}$

There is a lot of information-such as an employee's off-hours activities-to which society does not believe employers should be entitled, even when relevant to employee productivity. ${ }^{318}$

Ultimately, decisions about what information is appropriate to disclose turn on how that information will be used. Society must weigh the value of the use of the information against the costs. Evaluating the use of the data requires analyzing its tendency to produce accurate judgments and, when the potential for accuracy exists, analyzing whether the types of judgments in question are desirable to society. Not all accurate judgments are desirable. For example, the disclosure that a person has AIDS might enable employers to make a rational decision that the person will be less productive than an equally qualified healthy employee. But, for many reasons, society may not want the employer to have the information to make such a decision. The same piece of information could enable a prospective spouse or lover to avoid having unprotected sex with the person. Most people would view this use of the information as more appropriate.

316. As Pauline Kim argues:

[T] he analogy between genetic discrimination, and race and sex discrimination, is fundamentally flawed.... In the employment context, race and sex discrimination are believed to be wrong because those characteristics are irrelevant to a worker's ability to perform the job. However, genetic technologies offer the potential to provide information that is arguably relevant to an employee's future job performance.

Pauline T. Kim, Genetic Discrimination, Genetic Privacy: Rethinking Employee Protections for a Brave New Workplace, 96 Nw. U. L. REV. 1497, 1500 (2002).

317. Id. at $1535-36$.

318. Id. at 1538 . 
3. Gossip and Judgments About Human Nature. Many disclosures about a person's private life are not made to those who have any particular need to judge that person. For example, a news story may disclose that John Doe has an unusual disease. Most readers will not know John Doe; and many people that do know him may not care enough to judge him at all. Under the judgment and trust critique as discussed thus far, the value of the disclosure to the public would be rather low if it does not help anybody make better judgments about John Doe.

Beyond making judgments about particular people, the judgment and trust critique also contends that disclosure of private information is important for making judgments about society in general. As Diane Zimmerman argues: "[G]ossip is a basic form of information exchange that teaches about other lifestyles and attitudes, and through which community values are changed or reinforced." ${ }^{, 319}$ She also contends that the tort of public disclosure should be abolished because "society has a powerful countervailing interest in exchanges of accurate information about the private lives and characters of its citizenry.",320

According to this argument, the value of disclosure is its educational benefits. Revealing private details about people can be highly instructive. For example, the exposure of people's sexual lives in the sexual revolution of the 1960s and 1970s was liberating to many, and through the greater disclosure of sexual practices, social norms changed. Privacy can inhibit the development of norms because it hides certain conduct and activities from public view, allowing society to avoid confronting them. In Zimmerman's words, "the exchange of information is crucial to the cohesiveness of the community and to the full development of all its members., ${ }^{, 21}$

However, much of the time, the purpose and function of gossip is not to educate, but to entertain, to thrill, and to satisfy idle curiosity. As Warren and Brandeis write: "Each crop of unseemly gossip, thus harvested, becomes the seed of more.... [Gossip] both belittles and perverts. It belittles by inverting the relative importance of things. . . . When personal gossip attains the dignity of print, [it] crowds the space available for matters of real interest to the community." ${ }^{322}$ Thus,

319. Zimmerman, supra note 29, at 334.

320. Id. at 341 .

321. Zimmerman, supra note 256 , at 829.

322. Warren \& Brandeis, supra note 8, at 196. 
gossip comes at a price: It detracts from other matters that may be more important.

Although in the abstract gossip can educate people about lifestyles and attitudes, this claim seems somewhat overblown. What precisely is the educative value of a celebrity's sex life, drug use, or dating history? True, these celebrities may become spokespeople for particular causes, but they often do so at their own initiative. Does society really need to thrust people into such a role when so many others seem willing to do so voluntarily? There are countless people willing to participate in reality television, or to go on talk shows and speak on virtually everything about their lives. With so many willing volunteers, what is the marginal value of adding the unwilling to the ranks?

Despite the fact that people may be curious about the private lives of others, they routinely recognize that curiosity should be limited. One may want to read the diary of a spouse or friend, but may restrain herself from doing so. This is because of certain social norms of restraint. ${ }^{323}$ Satisfying one's curiosity is not an absolute value. In other words, just because people are curious does not mean that they should be entitled to have information. Not all itches ought to be scratched.

With regard to private figures, the educative function of gossip could readily be satisfied without revealing the identities of the individuals involved. Returning to the example of John Doe's unusual disease, most people watching or reading the news do not care about Doe's identity. The story is interesting because of the particular disease, not because of who Doe is. As I discussed in Part I, privacy law should move beyond abstractions and focus on particular uses. If the disclosure is helpful because it educates people about human nature (rather than improves judgments about individuals whom people already know), then revealing the identity of a person often is unnecessary.

One might reply that if the disclosure does not lead anybody to judge Doe differently, then what is the harm to Doe in revealing his identity? The harm is that people often feel as though they are being judged. When personal information about someone is leaked, that person may constantly wonder whether particular people know about it and how the information might change people's perceptions. This

323. See Post, supra note 33, at 957 (arguing that the common law tort of invasion of privacy safeguards social norms, which he calls "rules of civility"). 
can create a significant sense of unease. The fear of being judged can be even more harmful than actually being judged. It can interfere with one's life in a profound way. Even if people are judged more favorably than they might fear, they still must live wondering what others really think of them. Protecting against disclosure prevents this type of harm.

Thus far, I have discussed instances in which gossip fails to provide much value. Although I believe that Zimmerman's gossip argument overreaches in its assessment of gossip's value, there are indeed many instances when gossip can be educative and when disclosure of a person's private information helps to change certain social norms. This argument is frequently raised in support of the outing of gays. ${ }^{324}$ Outing gays, the argument goes, will help alter society's perception of gays by demonstrating that mainstream people or role models are gay. According to Jean Cohen, many scholars argue that privacy is more harmful than helpful to gays because the "closet" becomes a prison, a shameful place where gays should hide. ${ }^{325}$ Cohen aptly responds that there is a difference between privacy that is forced upon a person and privacy that is chosen. ${ }^{326}$ Anita Allen also recognizes this distinction: "[C]oercive collective authority is properly marshaled both to protect 'wanted' privacy from the 'unwanted gaze' and to protect 'unwanted' privacy from the 'wanted gaze.' Privacy could, in effect, be imposed on the unwilling or uninterested.",327 According to Allen, the question of when privacy should be imposed or should be a matter of choice is a difficult one, and it must be analyzed based on the need for overriding individual choice. ${ }^{328}$

Paul Schwartz is correct to criticize what he calls "over-zealous norm entrepreneurs" who seek to change social norms by releasing personal information about others. ${ }^{329}$ Schwartz demonstrates that the social costs of such efforts to change these norms often outweigh the

324. See, e.g., Kathleen Guzman, About Outing: Public Discourse, Private Lives, 73 WASH. U. L.Q. 1531, 1568 (1995) ("Outers offer up the victim as a 'sacrificial lamb' to portray themselves as purifying redeemers, able to solve the problems of discrimination.").

325. Jean L. Cohen, Is Privacy a Legal Duty?, in Public And Private: Legal, Political, ANd Philosophical Perspectives 117, 122-24 (Maurizio Passerin d'Entreves \& Ursula Vogel eds., 2000).

326. Id. at 125 .

327. Anita L. Allen, The Wanted Gaze: Accountability for Interpersonal Conduct at Work, 89 GEO. L.J. 2013, 2015 (2001).

328. Id. at 2017-18.

329. Schwartz, supra note 209 , at 843. 
benefits. Norm entrepreneurs who disclose personal data about others create social costs, fostering an atmosphere of coercion, blackmail, and witch hunts. ${ }^{330}$ Ironically, norm entrepreneurs may increase the oppressiveness of the norms they seek to displace, and they can expose information that increases the power of the state. ${ }^{331}$

It is true that if the veils on people's lives were all removed simultaneously, society might collectively discard certain norms. However, the process of changing norms is complicated, and it is far from certain that massive disclosure would effectuate a change in norms. ${ }^{332}$ Further, in reality disclosure is haphazard, so the number of people subject to disclosure will rarely be enough to force a change in norms.

Human judgment is a profoundly important yet destructive activity. Although judging others is essential to basic social relationships, judgments can be hasty, distorted, irrational, and undesirable. They can cause immeasurable harm. The law certainly cannot stop people from judging each other, but it can help people control some of the information that might be used to make judgments about them.

\section{Problems with Regulating Judgment.}

a. The Problem of Paternalism. Some might counter that people are entitled to make their own assessments of others in the manner of their choosing even if many would find their judgments irrational. Volokh argues that "in a free speech regime, others' definitions of me should primarily be molded by their own judgments, rather than by my using legal coercion to keep them in the dark." ${ }^{333}$ In other words, privacy is paternalistic. It denies people information because it distrusts them to make informed choices. If people desire to make bad judgments about others based on partial information, it is their prerogative. What business does the law have in telling people how they should judge other people?

330. Id. at $842-43$.

331. Id. at 843 .

332. See Elwood, supra note 254, at 773 ("Even under the best of circumstances, the relationship between outing a particular figure and effecting a societal change is simply too attenuated to override the outing target's privacy rights.").

333. Volokh, supra note 32, at 1093. 
Certainly, the fact that some people may consider personal information relevant to their decisions cannot be ignored. Society must weigh the value of disclosure against the distorting effects it might have, as well as against its other negative social effects. Although the fact that the legal system must conduct this balancing may not be ideal, this is the way that many issues of fundamental importance to our society are determined, such as equal protection, due process, and freedom of association. At some point, the value of true information is outweighed by other concerns.

Once again, evidence law provides a good example. At trials, courts routinely restrict the introduction of certain information to juries who must make very important decisions, often with profound implications for the safety of society (for example, whether to convict a serial killer or terrorist). Even relevant evidence can be excluded from a trial because it is more prejudicial than probative. ${ }^{334}$ Although certain information can be very helpful in assessing another person, and more information can often be preferable, with certain types of information, society knows that judgments are not always fair and recognizes that keeping such information private will not impede fair judgment." ${ }^{335}$

Failing to police the disclosure of personal information does more than just interfere with people's private autonomy and independence-it has larger effects on participation in the public sphere. As many commentators have pointed out, the bright spotlight of the media can deter capable people from seeking public office or speaking publicly about important issues. ${ }^{336}$ It can limit the public sphere to a particular type of individual-one who enjoys letting it all hang out, who loves the spotlight. It can deter all those who have engaged in some deviant activity or who have a few eccentricities. This has the result of de-democratizing the public sphere to a select group of individuals, and it impairs the opportunity to engage in

334. See FED. R. EVID. 403 ("Although relevant, evidence may be excluded if its probative value is substantially outweighed by the danger of unfair prejudice, confusion of the issues, or misleading the jury, or by considerations of undue delay, waste of time, or needless presentation of cumulative evidence.").

335. See Anita L. Allen, Lying to Protect Privacy, 44 VILL. L. REV. 161, 178 (1999) (discussing Oscar Wilde's concealment of his homosexuality to avoid the "derogatory meanings others in his society brought to their understandings of homosexuality").

336. See, e.g., Robert N. Bellah, The Meaning of Reputation in American Society, 74 CAL. L. REV. 743, 746 (1986); Richard Davis, Supreme Court Nominations and the News Media, 57 ALB. L. REV. 1061, 1062 (1994); Sean M. Scott, The Hidden First Amendment Values of Privacy, 71 WASH. L. REV. 683, 710 (1996). 
public life. Another result is that the public sphere itself is diminished because it becomes filled with certain personality types who do not mind radical publicity of their faults, who live bland and uninteresting lives, or who enjoy the risk of public discovery. As Thomas Nagel argues, there is a great harm caused by the fact that the public "feels entitled to know the most intimate details of the life of any public figure. ${ }^{337}$ The harm is that the public sphere is damaged because "[m]any people cannot take that kind of exposure."

Disclosure protections should not simply be dismissed as paternalistic impositions on social judgment. Such paternalism may be self-imposed by a society through norms of restraint. Legal protections of privacy often emerge from community norms. As Robert Post observes, privacy "safeguards rules of civility that in some significant measure constitute both individuals and community." ${ }^{, 39}$ Of course, one might argue that the rights of individuals to do what they want should trump the interests of society as a whole. I contend that when it is socially beneficial to protect individual autonomy, the law should do so. Individual rights, though, should not be viewed as trumps; as John Dewey aptly argues, rights should be understood instrumentally in light of "the contribution they make to the welfare of the community." ${ }^{340}$ There are many instances in which society has strong interests in telling people how to judge others, and these interests can outweigh individual autonomy in judging others. For example, few people would object to society's restricting judgments based on racial bias.

An apt analogy can be made to Ulysses and the Sirens:

[Sirens] weaving a haunting song over the sea

we are to shun, she said, and their green shore

all sweet with clover; yet she urged that I

alone should listen to their song. Therefore

you are to tie me up, tight as a splint,

erect upon the mast, lashed to the mast,

and if I shout and beg to be untied,

take more turns of the rope to muffle me. ${ }^{341}$

337. Thomas NAGEl, CONCEALMENT AND EXPOSURE \& OTHER ESSAYs 3 (2002).

338. Id.

339. Post, supra note 33, at 959.

340. John Dewey, Liberalism and Civil Liberties, Social Frontier 2, Feb. 1936, at 137, reprinted in 11 THE LATER WORKS, 1925-1953, supra note 135, at 373.

341. HOMER, THE OdYSSEY bk. XII, 11. 190-98, at 214 (Robert Fitzgerald trans., Vintage Books 1990). 
Ulysses desires to be self-restrained; he wants to be tied up because he knows that he might not be able to control himself. Similarly, people may recognize the value of being restrained from learning certain details about others, even if they crave gossip and would gain much pleasure from hearing it. Curiosity is an important desire, for it leads to our quest for knowledge. But it can also be harmful, and society has norms about the appropriate level of gossip. Privacy protections represent society tying itself to the mast. This is not an external paternalistic restriction, but one that is internal and selfimposed.

Indeed, the First Amendment is also a vehicle for society to restrain itself. The First Amendment prevents a society from passing laws that infringe upon free speech. Ironically, the self-restraint of the First Amendment often clashes with the self-restraint of privacy protections. ${ }^{342}$ In this way, the First Amendment is paternalistic, for it restrains society from passing many laws and regulations that it desires to enact. Disclosure protections indirectly restrain individuals from judging based on certain information, by restricting the public disclosure of that information. Although the First Amendment restrains government, whereas disclosure protections restrain individuals, both doctrines exercise restraint to achieve similar goals - promoting autonomy and democratic self-governance. For some of the very same reasons that society cherishes the restraints of the First Amendment, it should also cherish the restraints of privacy protections. In short, there is no escape from paternalism. Both free speech and privacy are paternalistic, just in different ways. Therefore, the issue becomes what kinds of paternalism society wants and for what purposes.

b. Dissonance and Deception. Although it is hard to dispute that the self is complicated and that everyone plays different roles in different contexts, this does not necessarily imply that the law should actively promote role-playing. Indeed, people would be uncomfortable around those who were too chameleon-like, radically changing their personalities in every situation. Maybe less dissonance between people's different roles would produce more well-adjusted individuals, better able to reconcile the different aspects of their lives. Perhaps privacy is bad for the self.

342. I contend that neither form of social self-restraint is absolute, and, therefore, when there is conflict, a balancing must take place. 
Although less dissonance between public and private roles might seem desirable initially, such dissonance need not be problematic. Of course, too much dissonance may be troublesome, and the appropriate degree of dissonance for mental and emotional wellbeing is a question that psychiatrists are best equipped to answer. The paternalism argument, as applied to this issue, could cut in favor of privacy protections. It would be paternalistic for the law to fail to respect the choices that individuals make regarding the degree of dissonance tolerable in their public and private lives. The law should protect people's choices in this area, as these choices further individual autonomy. Of course, because autonomy is not absolute, it is important to consider community norms. As Thomas Nagel observes: "One might well ask how it is that we can remain on good terms with others when we know that behind their polite exteriors they harbor feelings and opinions that we would find unacceptable if they were expressed publicly." ${ }^{343}$ Society has come to accept the fact that there is dissonance between public and private selves. For example, people not only accept the telling of white lies, but even deem them necessary in many contexts. As Nagel further observes: "One of the remarkable effects of a smoothly fitting public surface is that it protects one from the sense of exposure without having to be in any way dishonest or deceptive, just as clothing does not conceal the fact that one is naked underneath." ${ }^{344}$

Nagel's observations suggest a key point—society recognizes and accepts the fact that the public self is a partly fictional construct. The public self is constructed according to social norms about what is appropriate to expose in public. Notably, people may even feel uncomfortable when other people reveal too many personal details about themselves. For example, if a person describes in detail her medical and psychological conditions, many people consider this "too much information," which may make social situations uneasy. Movies and literature abound with awkward situations of too much personal information in public, such as a couple laying bare intimate details about their relationship, or a person disclosing another's deep secrets, or a friend revealing another's sexual exploits. Generalizing from this very complex set of norms, society expects the public self to be more buttoned-up than the private self.

343. NAGEL, supra note 337 , at 7.

344. Id. 
Of course, dissonance can go too far. With too much dissonance, people may begin to feel deceived by another person. Dissonance is not deception, although the line between them is not a sharp one. But the lack of a clear line does not mean that there is no distinction between dissonance and deception. The terms merely denote a boundary between what people perceive as acceptable fictions and unacceptable ones. As Goffman notes, people will view someone as an impostor or fraud when they believe that the person is not "authorized to give the performance in question." ${ }^{345}$ There are many "shadings between lies and truths." ${ }^{346}$ Because people play many roles, "there is often no reason for claiming that the facts discrepant with the fostered impression are any more the real reality than is the fostered reality they embarrass." ${ }^{347}$ What is acceptable versus what is out of bounds depends upon social norms, which are complex and subtle enough to recognize that people do play discrepant roles.

Another difficulty with protecting against disclosures is that such protections, even if justified as protecting a socially acceptable degree of dissonance, may in practice promote deception. Sometimes, people wear masks to hide who they are. For example, politicians may masquerade as impeccable moral leaders when in fact they commit the very sins against which they preach. I am certainly not arguing that because the self plays many roles, there is no deception or duplicity. People lie about themselves all the time. Sometimes these lies are trivial; but other times these lies are quite important, and disclosure protections can prevent the revelation of information that might desirably expose these falsehoods. However, as Anita Allen correctly contends, lying should not be viewed as a "categorical moral wrong." ${ }^{348}$ In particular, Allen argues that sometimes deception is justified to protect sexual privacy-even for public figures. ${ }^{349}$ For Allen, sexual privacy can outweigh the value of truth. She illustrates her argument by discussing Oscar Wilde's concealment of his homosexuality. ${ }^{350}$ According to Allen, Wilde was justified in lying:

345. GOFFMAN, supra note 292, at 59.

346. Id. at 62 .

347. Id. at 65 .

348. Allen, supra note 335, at 161 .

349. Id. at 161-63; see also Allen, supra note 194, at 1167 (balancing the value of exposing the sexual misconduct of public figures against the value of protecting their privacy).

350. Id. at $178-79$. 
Wilde lied because he was unable through force of character and art to persuade an entire society of what he thought was the true nature and significance of his relationships with men, and unable to get his wife, the world or Queensberry to see these relationships' true meaning and his true identity. ${ }^{351}$

The fact that deception can and does occur does not mean that all disclosures are socially beneficial. Still, many disclosures are. Although it is impossible to create easy rules, this does not mean that society must abandon efforts to protect against disclosures. Some information is more distorting and unhelpful in particular contexts. The key point is that information cannot be detached from its uses. Information is relevant to certain inquiries, but not to others. Often, discussions about privacy focus on the information alone. But information must be linked to its uses, for this is the best way to assess whether to protect against disclosures.

It is hard to ever say that a particular piece of information is always helpful or harmful, relevant or irrelevant. The debate over disclosures often fails to focus on uses, and it is hard to reach a meaningful balance between privacy and disclosure without such a focus. Disclosure is often seen as all or nothing; if disclosure is justified, it must be justified for everyone in every context. By understanding disclosure to involve levels of access to information based on the information's uses, it becomes possible to modulate when disclosures are appropriate. We should not ask: Can this information be disclosed? Instead, the better question is: In this context, should the information be disclosed for this use?

\section{B. Concealing the Past: Growth and Reformation}

The discussion in the preceding Section suggests that in cases in which information will not lead to more accurate judgments the law should restrict disclosure. But in many instances, accuracy is increased by disclosure. In these cases, it can still be justifiable to restrict disclosure when the increase in accuracy is outweighed by the values promoted by protecting privacy.

One of the values of protecting privacy is facilitating growth and reformation. The self is not fixed, but grows throughout an entire lifetime. ${ }^{352}$ At any given moment, the self is merely a snapshot.

351. Id.

352. See DEWEY, supra note 67, at 210. 
According to John Dewey, the individual is not "something complete, perfect, finished, an organized whole of parts united by the impress of a comprehensive form," but is "something moving, changing, discrete, and above all initiating instead of final., ${ }^{, 353}$ A person is a life process from cradle to corpse. At any given moment, we are seeing just a snapshot in time, a slice of this lifelong process. Playwright and author Friedrich Dürrenmatt put it eloquently:

[W] hat one commonly called one's self was merely a collective term for all the selves gathered up in the past, a great heap of selves perpetually growing under the constant rain of selves drifting down through the present from the future, an accumulation of shreds of experience and memory, comparable to a mound of leaves that grows higher and higher under a steady drift of other falling leaves. .

Most people have embarrassing moments in their past. Everyone has done things and regretted them later. In childhood, they may have acted with great immaturity, done cruel things to others, or done things that make them ashamed. There is a great value in allowing individuals the opportunity to wipe the slate clean. Society protects against such disclosures not just to protect the individual, but to further society's interest in providing people with incentives and room to change and grow. Of course, people should not always be able to escape disclosure of their past conduct, for one's past partly defines who one is. However, the past is not wholly determinative.

Protection against disclosure permits room to change, to define oneself and one's future without becoming a "prisoner of [one's] recorded past." ${ }^{355}$ Society has a tendency to tie people too tightly to the past and to typecast people in particular roles. The human

353. Id. at 167; see also John Dewey, Human NATURE AND Conduct 97 (Jo Ann Boydston ed., S. Ill. Univ. Press 1988) (discussing "the difference between a self taken as something already made and a self still making through action"). As psychologist Carl Schneider notes, protection against disclosure is similar to the skin of a fruit or the shell of an egg. CARL D. Schneider, Shame Exposure And Privacy 37 (1992); see also David L. Bazelon, Probing Privacy, 12 GONZ. L. REV. 587, 590 (1977) (“[P]rivacy shelters the emerging individual's thoughts from public disclosure and control so that the fear of being watched, exposed, ridiculed, or penalized does not crush the seeds of independent thinking before they can mature.").

354. Friedrich Dürrenmatt, The Assignment 24 (Joel Agee trans., Random House 1988).

355. Secretary's Advisory Comm. on Automated Pers. Data Sys., U.S. DeP'T of Health, Educ. \& Welfare, Pub No. (05) 73-94, Records, Computers, AND the Rights OF CITIZENS (1973), at http://aspe.os.dhhs.gov/datacncl/1973privacy/tocprefacemembers.htm. 
personality is dynamic, yet it is frequently difficult to accept the complete implications of this fact. Disclosure can lead to the creation of a permanent record about people, baggage that they must constantly carry around and explain. For example, a thirty-four-yearold professional named Michael wrote a few articles in specialized journals while briefly in prison when he was a juvenile. ${ }^{356}$ Michael never imagined the rise of Google, a search engine that can comb the Internet for every article mentioning a person's name. When Michael dates, women ask him about his stint in prison:

"When you meet someone," Michael says, "you don't say, 'I had an affair one time,' or 'I was arrested for DUI once,' or 'I cheated on my taxes in 1984." Since then, there have been other confrontations, but what Michael finds most disturbing are the sudden silences. "Instead of thinking, 'Was I curt last week?' or 'Did I insult this political party or that belief?' I have to think about what happened when I was 17." ${ }^{357}$

In one instance, Michael was interviewed several times for a job when, suddenly, the potential employer began ignoring him: "[Michael's] hunch: Someone Googled him. But the worst part is, he'll never know." ${ }^{358}$

When personal information is disclosed in today's age, it is routinely archived and often becomes instantly available. Michael's problem is not that he is embarrassed by his past or wants to escape from it. Rather, he dislikes having to constantly justify himself and explain away his past baggage. Worse still, he is rarely afforded the opportunity to explain.

Of course, it may be rational for people to shun those with problems in their pasts. Much depends upon whether people who have exhibited troubled behavior in the past are more likely to exhibit similar behavior in the future than are those without such histories. However, even if people with troubled pasts are more of a risk to befriend, trust, or employ, there remain social benefits to providing them with the freedom to change and grow.

356. Neil Swidey, A Nation of Voyeurs: How the Internet Search Engine Google Is Changing What We Can Find Out About Each Other and Raising Questions About Whether We Should, Boston Globe MAG., Feb. 2, 2003, at 10.

357. Id.

358. Id.; see also Jennifer 8. Lee, Trying to Elude the Google Grasp, N.Y. TIMES, July 25, 2002, at G1 ("[T]he combined power of the Internet, search engines and archival databases can enable almost anyone to find information about almost anyone else...."). 
The great difficulty is in how to deal with the concealment of criminal pasts. This information can be highly relevant for whether people trust a person, especially when a person with a history of violent criminal conduct has contact with children. Many people with such histories are not rehabilitated and are at high risk to commit future crimes. ${ }^{359}$ On the other hand, there is an important social value in providing people with the opportunity to reform their lives. For example, in Melvin v. Reid, ${ }^{360}$ a former prostitute had left the business long previously and had established a new life. A film, entitled "The Red Kimono," depicted her life story and used her maiden name. She sued under the tort of public disclosure. The court held that, although the story of her life could be disclosed, there was no need to use her real name. The court noted that a central objective of society was the "rehabilitation of the fallen and the reformation of the criminal."," "Where a person has by his own efforts rehabilitated himself," the court observed, "we, as right-thinking members of society, should permit him to continue in the path of rectitude rather than throw him back into a life of shame or crime." ${ }^{362}$

The question of when to permit people to conceal their criminal pasts cannot be decided categorically. If society is committed to rehabilitation, then it must genuinely provide people with an opportunity to reform themselves. Such an opportunity can be impeded by stigma and shunning that can result from disclosure. Protections can restrict the instances of disclosure of criminal pasts to when such information is most relevant and socially beneficial for others to know.

But why should rehabilitation outweigh the social value of knowing about another's sordid past? As noted already, people may rationally conclude that it is better not to risk trusting people with a criminal past. There are plenty of other people worth trusting. Recidivism rates are quite high. Many ex-convicts do commit crimes again. Sex offenders do reoffend. Why not let people make up their own minds? Does rehabilitation outweigh society's interest in

359. See generally T. Markus Funk, The Dangers of Hiding Criminal Pasts, 66 TENN. L. REV. 287 (1998) (arguing that expunging certain juvenile crimes from a person's record is a mistake).

360. 297 P. 91 (Cal. 1931).

361. Id. at 93 .

362. Id. 
allowing people to make accurate judgments about individuals who committed crimes in the past?

Rehabilitation is valuable, and the United States has a long tradition of acknowledging the possibility of rehabilitation. Indeed, some of this country's colonial settlers were convicted criminals, transported here for their crimes. ${ }^{363}$ As Lawrence Friedman observes:

American society is and has been a society of extreme mobility, in every sense of the word: social, economic, geographical. Mobility has meant freedom; mobility has been an American value. People often moved from place to place; they shed an old life like a snake molting its skin. They took on new lives and new identities. They went from rags to riches, from log cabins to the White House. American culture and law put enormous emphasis on second chances. ${ }^{364}$

Society's commitment to providing people opportunities to change is illustrated by the fact that most states have laws that expunge juvenile criminal records when the juvenile reaches adulthood. ${ }^{365}$ As one court observed, "an unexpunged juvenile record may create a lifelong handicap because of the stigma it carries." ${ }^{366}$

One could counter that rehabilitation is an American myth; the rehabilitated criminal that is chronicled in literature and the movies is an idealized hero, not a realistic figure. However, despite the difficulties with rehabilitation, it still remains a deep-rooted tradition. Our criminal justice system engages in frequent and extensive efforts to rehabilitate, such as prison education programs and boot camps.

The benefits of rehabilitation are difficult to reject, especially in a criminal justice system from which most criminals are released back into society. Perhaps under different conditions, rehabilitation could be more readily abandoned. But the very structure of our penal system makes the goal of rehabilitation an important one that cannot be ignored.

363. Sarah Bilder, The Struggle Over Immigration: Indentured Servants, Slaves, and Articles of Commerce, 61 Mo. L. REV. 743, 756-57 (1996).

364. Lawrence M. Friedman, Name Robbers: Privacy, Blackmail, and Assorted Matters in Legal History, 30 Hofstra L. REV. 1093, 1112 (2002).

365. See Funk, supra note 359, at 288 (suggesting that state laws permitting the expunging of juvenile criminal records are "grounded on a belief that juveniles will outgrow their reckless youthful behavior").

366. People v. Price, 431 N.W.2d 524, 526 (Mich. Ct. App. 1988). 
This rather abstract discussion can be assisted by some examples. A very difficult case involving the disclosure of a person's criminal past is Briscoe v. Reader's Digest Ass' $n .^{367}$ In Briscoe, a magazine article disclosed the fact that the plaintiff had once hijacked a truck. The crime had occurred eleven years previously, and Briscoe had established a new life. His friends, family, and young daughter were not aware of his criminal past. ${ }^{368}$ The court held that, although Briscoe's crime was newsworthy, he could sue for the use of his name, which was not relevant to the article. ${ }^{369}$ The court reasoned:

One of the premises of the rehabilitative process is that the rehabilitated offender can rejoin that great bulk of the community from which he has been ostracized for his anti-social acts. In return for becoming a 'new man,' he is allowed to melt into the shadows of obscurity.

On the Briscoe case, Volokh argues: "While criminals can change their character ... they often don't. Someone who was willing to fight a gun battle with the police eleven years ago may be more willing than the average person to do something bad today, even if he has led a blameless life since then." ${ }^{, 371}$ Although the information about Briscoe "may have little to do with broad political debates," it is of "legitimate public concern" for "people who know Briscoe, the very same group whose ignorance Briscoe seemed most concerned about preserving." ${ }^{372}$

However, the article was not written for the purpose of informing people who knew Briscoe about his past. Volokh's argument focuses on information about ex-convicts in the abstract. In Briscoe, the article had nothing to do with Briscoe. This was not a disclosure to Briscoe's friends or family by a person concerned about their safety. Rather, it was a disclosure of Briscoe's identity in connection with an article about hijacking. There was no need to identify Briscoe in order to tell the story. As I have argued throughout this Article, the law should not evaluate a disclosure without considering context.

The value of rehabilitation is not absolute. The balancing approach that I recommend requires weighing the value of

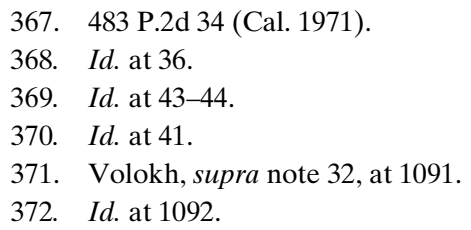


rehabilitation against the value of the use of the information in the context in which it is disclosed. Focusing on the information in the abstract-for any possible use-will invariably reveal a set of circumstances or a particular use valuable enough to justify a disclosure. Critics of disclosure restrictions often point to these instances. However, although these critics may prove that privacy sometimes is outweighed by the need for disclosure, they do not demonstrate that disclosure is justifiable under all circumstances.

As I discussed earlier, it is best to avoid dissociating information from its uses. To balance rehabilitation against the benefits of disclosure, one must look to the uses of information that the disclosure serves. For example, the Fair Credit Reporting Act (FCRA) restricts the disclosure of criminal history information over seven years old on a credit report in some contexts. ${ }^{373}$ The FCRA represents a judgment that one's prior criminal history becomes stale and not relevant for the purposes of credit after a period of years. The balance that FCRA strikes must be understood not in the abstract, but in terms of the information's relevance to how credit reporting agencies are using it. Criminal history information has some relevance to assessing creditworthiness, but it is not highly relevant.

Perhaps one of the most difficult issues involves Megan's Laws, which establish public databases containing various personal information about sexual offenders, such as their photographs, addresses, prior convictions, and places of employment. ${ }^{374}$ Megan's Laws exist in all fifty states, many created in response to Congress's 1996 Megan's Law. ${ }^{375}$ A number of states post Megan's Law information on the Internet.

In support of Megan's Law, it is hard to argue that the safety of children does not outweigh the rehabilitative benefits and the dignitary harms to sex offenders. Supporters of Megan's Law point to high recidivism rates for sexual offenders. ${ }^{376}$ However, there are

373. 15 U.S.C. $§ 1681$ c(a)(5) (2000).

374. Megan's Laws are named after Megan Kanka, a seven-year-old girl in New Jersey who was raped and murdered by a neighbor with two earlier sexual assault convictions. DANIEL J. SOlOVE \& MARC Rotenberg, INFORMATION PRIVACY LAW 391 (2003).

375. See Megan's Law § 2, 42 U.S.C. § 14,071(e) (2000) (authorizing states to release relevant information about persons required to register under the Act when "necessary to protect the public.").

376. See Doe v. Poritz, 662 A.2d 367, 374 (N.J. 1995) (“[S]uccessful treatment of sex offenders appears to be rare."); Daniel L. Feldman, The "Scarlet Letter Laws" of the 1990s: A Response to Critics, 60 ALB. L. REV. 1081, 1104-05 (1997) ("Megan's Law provides some degree of additional protection for communities against ... sex offenders, who tend, as a group, to have 
reasons to doubt the underlying assumptions in this balancing. There is little proof that Megan's Law disclosures protect the safety of children. Of course, there is also not much proof that Megan's Laws fail. What is better documented is that when the identities of sexual offenders are revealed through Megan's Law disclosures, these people can be harassed and threatened. There are numerous cases of attempts at vigilante justice and violence against the sex offenders. ${ }^{377}$ They may lose their jobs and be ostracized. This may increase the likelihood that sexual offenders will commit new crimes. Additionally, in certain cases, a Megan's Law can sweep too broadly. Some Megan's Laws include a wide range of offenses, such as sodomy, prostitution, consensual homosexual acts, and masturbation in public. ${ }^{378}$ The disclosures under Megan's Laws sometimes do not reveal whether the offender was convicted for a relatively minor crime, such as consensual sodomy, or a more serious and violent one, such as rape. Pedophiles are sometimes classified the same as high school students convicted of statutory rape by having sex with their underage girlfriends or boyfriends. ${ }^{379}$

Another difficulty with Megan's Laws is that most sexual offenses against children are committed by family members or close family friends -92 percent under one estimate. ${ }^{380}$ Often, not just the offenders feel embarrassment and stigma when their status as sex offenders is disclosed-so do members of their families. Ironically, Megan's Laws may stigmatize the very victims of sex offenses whom they are designed to protect, many of whom are children living in the same house as the sex offender.

unusually high rates of recidivism."); Susan Deschler Oakes, Megan's Law: Analysis on Whether It Is Constitutional to Notify the Public of Sex Offenders Via the Internet, 17 J. MARsHALL J. COMPUTER \& INFO. L. 1133, 1134 (1999) ("Sex offenders are nine times more likely to repeat their crimes than any other class of criminals.").

377. See Stacey Hiller, Note, The Problem with Juvenile Sex Offender Registration: The Detrimental Effects of Public Disclosure, 7 B.U. PUB. INT. L.J. 271, 286 (1998) (describing incidents of violence against sex offenders whose names had been made public).

378. See Jane A. Small, Note, Who Are the People in Your Neighborhood?: Due Process, Public Protection, and Sex Offender Notification Laws, 74 N.Y.U. L. REV. 1451, 1456 (1999) (listing offenses that fall within the definition of "sex offender").

379. See Stephanie Simon, Ex-Cons Exiled to Outskirts: Iowa Sex Offenders, Forbidden to Live Within 2,000 Feet of Schools and Child Care Centers, Must Crowd Into Pockets of Desolate Housing, L.A. TIMES, Dec. 5, 2002, at A1 (describing the law in Iowa).

380. Michele L. Earl-Hubbard, Comment, The Child Sex Offender Registration Laws: The Punishment, Liberty Deprivation, and Unintended Results Associated with the Scarlet Letter Laws of the 1990s, 90 NW. U. L. REV. 788, 851-52 (1996). 
I am not prepared to conclude that Megan's Laws are categorically undesirable. Megan's Law disclosures may be relevant for certain types of relationships, such as child care. Still, most Megan's Laws lose sight of the use of the information in question. Megan's Law data are beneficial when disclosed for certain purposes, but not necessarily for all purposes. When placed on the Internet for any curious individual around the world to see, Megan's Law information becomes disconnected from its goals.

In New Jersey, in Paul P. v. Farmer, ${ }^{381}$ the court made an attempt to appropriately balance privacy with the benefits of disclosure. To receive information, the recipient had to sign a form agreeing to share information only with members of her household and caregivers for her children. Unfortunately, New Jersey subsequently amended its Constitution by referendum to place Megan's Law data on the Internet. ${ }^{382}$ In an even more extreme approach, one judge in Texas ordered sex offenders to post signs in their front yards declaring: "Danger! Registered Sex Offender Lives Here." 383 The judge also required them to place bumper stickers on their cars: "Danger! Registered Sex Offender in Vehicle." 384

If the goal of Megan's Law is to punish, to return to the shaming punishments of the colonial era, where people were branded, mutilated, or adorned with scarlet letters, ${ }^{385}$ then these approaches certainly further that goal. But the Supreme Court has held that punishment is not the purpose of Megan's Laws. In Smith v. Doe, ${ }^{386}$ the Supreme Court examined whether Alaska's Megan's Law violated the constitutional prohibitions on ex post facto laws. ${ }^{387}$ The Court noted that if the sex offender registration and notification law is designed to "impose punishment" then it "constitutes retroactive punishment" and is an impermissible ex post facto law. ${ }^{388}$ Moreover, even if the law is not designed to punish, the law will violate the Ex

381. 80 F. Supp. 2d 320 (D.N.J. 2000), aff'd, 227 F.3d 98 (3d Cir. 2000).

382. Maria Newman, Naming Sex Offenders on the Internet Passes in New Jersey, N.Y. TiMES, Nov. 8, 2000, at B16.

383. SOLOVE \& ROTENBERG, supra note 374 , at 400.

384. Id.

385. Toni M. Massaro, Shame, Culture, and American Criminal Law, 89 MicH. L. Rev. 1880, 1913 (1991).

386. 123 S. Ct. 1140 (2003).

387. Pursuant to Article I, section 9 of the U.S. Constitution, "No . . . ex post facto Law shall be passed" by the federal government. Pursuant to Article I, section 10, "No state shall ... pass any ... ex post facto Law."

388. Smith, 123 S. Ct. at 1146-47. 
Post Facto Clause if it is "so punitive either in purpose or effect as to negate [the State's] intention to deem it civil.",389

Alaska's Megan's Law makes public the following information:

$[\mathrm{N}] \mathrm{ame}$, aliases, address, photograph, physical description, description [,] license [and] identification numbers of motor vehicles, place of employment, date of birth, crime for which convicted, date of conviction, place and court of conviction, length and conditions of sentence, and a statement as to whether the offender or kidnapper is in compliance with [the update] requirements . . . or cannot be located. ${ }^{390}$

Deferring to the Alaska legislature, the Court concluded that "the intent of the Alaska Legislature was to create a civil, nonpunitive regime." ${ }^{391}$ Moreover, the effect of the law did not "negate Alaska's intention to establish a civil regulatory scheme." ${ }^{392}$ The Court dismissed the argument that Alaska's Megan's Law resembles a shaming punishment:

[T]he stigma of Alaska's Megan's Law results not from public display for ridicule and shaming but from the dissemination of accurate information about a criminal record, most of which is already public. Our system does not treat dissemination of truthful information in furtherance of a legitimate governmental objective as punishment. . . The publicity may cause adverse consequences for the convicted defendant, running from mild personal embarrassment to social ostracism. In contrast to the colonial shaming punishments, however, the State does not make the publicity and the resulting stigma an integral part of the objective of the regulatory scheme.

The Court reasoned that although the "reach of the Internet is greater than anything which could have been designed in colonial times," the goal of Megan's Law notification is "to inform the public for its own safety, not to humiliate the offender . . . . The Internet makes the document search more efficient, cost effective, and convenient for Alaska's citizenry." ${ }^{394}$

389. Id. at 1147 (alteration in original) (internal quotation marks and citations omitted).

390. Smith, 123 S. Ct. at 1146 (quoting Alaska Stat. $§ 18.65 .087(b)$ (Michie 2002)) (second, third, and fourth alterations in original).

391. Id. at 1149.

392. Id. at 1154 .

393. Id. at 1150 .

394. Id. at $1150-51$. 
If, as the Court concluded with respect to Alaska's law, the purposes of Megan's Laws are to protect the safety of the community, then there are a myriad of less harmful ways to disclose the information than posting it on the Internet. Additionally, as the dissent observed, the Alaska law "makes no provision whatever for the possibility of rehabilitation... However plain it may be that a former sex offender currently poses no threat of recidivism, he will remain subject to long-term monitoring and inescapable humiliation. ${ }^{, 395}$ For example, the dissent discussed the plight of one of the sex offenders challenging the law. Prior to the enactment of the law, John Doe I pleaded nolo contendere to a sexual abuse charge. After successfully finishing a treatment program, he was granted early release. He remarried, created a business, and was even "granted custody of a minor daughter, based on a court's determination that he had been successfully rehabilitated. The court's determination rested in part on psychiatric evaluations concluding that Doe had 'a very low risk of re- offending' and is 'not a pedophile."”396

The sweep of Megan's Laws is often too broad. In a companion case to Smith, the Court upheld a Connecticut Megan's Law statute that applies to "all sex offenders-currently dangerous or not." ${ }^{\text {,397 }}$ This law's scope seems far more extensive than necessary to achieve the purpose of protecting community safety.

\section{Reassessing the Judgment and Trust Critique}

The judgment and trust critique argues that disclosure is more socially beneficial than privacy protections because personal information informs people about those around them and about human nature in general. In contrast to the free speech critique, the judgment and trust critique does not locate the value of information in one's right to speak or in self-governance. Nor does the value of disclosure lie in entertainment. Rather, the value stems from what personal information teaches people about others.

This critique must certainly be reckoned with. People need information to make judgments about others, and these judgments are important for how they live their lives and whom they trust. However, as I have argued, this critique goes only so far. In many instances, people's judgment is flawed. One often judges others out of

395. Id. at 1160 (Ginsburg, J., dissenting).

396. Id. (citations omitted).

397. Conn. Dep't of Pub. Safety v. Doe, 123 S. Ct. 1160, 1164 (2003). 
context. There are judgments that society wants to prevent, such as irrational judgments and even certain kinds of rational ones. As for gossip, although some of the time it can educate people about human nature, often it functions only to entertain. Moreover, the educative benefits of gossip can often be achieved by people's voluntary disclosure of details about their lives. If the purpose of gossip is to teach us lessons about human nature in general, there is often no need to identify individuals who desire privacy.

In short, although disclosure certainly can have a substantial social value, so can privacy. In fact, privacy can improve people's judgments about others, or at least prevent certain flaws in the judging process. Privacy can prevent harms to individuals, as well as provide people with freedom for self-exploration and room to change, grow, and rehabilitate themselves. Too much information, as with too much of almost anything, can be more detrimental than beneficial.

\section{CONCLUSION}

The manner in which the law regulates the disclosure of personal information is of profound importance. Privacy, in the form of protection against disclosure, regulates the way people relate to others in society. Among other things, it promotes one's ability to engage in social affairs, form friendships and human relationships, communicate with others, and associate with groups of people sharing similar values. Social judgment and social norms can impede these practices. People's lives in the public sphere are precarious, for they are constantly subject to the judgment of others and to the sting of social sanctions. It is because people care so much about their public lives, about how others in society regard and treat them, that protection against disclosure is important. Protection against disclosure opens up ways for people to communicate and associate with others without destroying or inhibiting our public roles. Protection against disclosure shields us from the harshness of social judgment, which, if left unregulated, could become too powerful and oppressive.

Nevertheless, both the free speech and the judgment and trust critiques remain quite compelling. Society values free expression and openness; and people often want to obtain personal information for a variety of purposes. In this Article, I have argued that in order to reconcile privacy with the value of communicating information, the law must steer away from absolutes and abstractions. Existing debates 
over disclosure protections often focus on information in the abstract. By contrast, I have argued that information must be considered in context, which means that the relationships in which the information is transferred and the ways in which it is used become the central focus of inquiry. Focusing on the context in which disclosures are made is the only meaningful way to assess the value of a particular disclosure against the costs. This task is a complex one, but it is worth the effort. Information flow and privacy are both extremely important values; finding the right balance will be critical to shaping the future of a world increasingly driven by information. 